\title{
Secondary Sexual Characteristics in the Galerucinae (Sensu Stricto) (Coleoptera: Chrysomelidae)
}

\author{
M. S. Mohamedsaid ${ }^{1}$ and D. G. Furth ${ }^{2}$ \\ ${ }^{1} 48$ Jalan SS 15/3A, Subang Jaya, Selangor 47500, Malaysia \\ ${ }^{2}$ National Museum of Natural History, Smithsonian Institution, Washington, DC 20013-7012, USA
}

Correspondence should be addressed to M. S. Mohamedsaid, msmohamedsaid@gmail.com

Received 27 January 2011; Accepted 3 March 2011

Academic Editors: M. Kuntner and T. Miyata

Copyright (C) 2011 M. S. Mohamedsaid and D. G. Furth. This is an open access article distributed under the Creative Commons Attribution License, which permits unrestricted use, distribution, and reproduction in any medium, provided the original work is properly cited.

\begin{abstract}
A list of 1298 species and 172 genera of Chrysomelidae from the subfamily Galerucinae (sensu stricto) with the males having at least one form of secondary sexual characteristic (SSC) is presented. The number of species amounts to $24 \%$ of the total Galerucinae presently known from all over the world-a very significant amount. The SSCs comprise various types of modified structures found on all parts of the body-head, thorax, and abdomen. They are not variable but species specific. Illustrations from selected 87 species that include 84 images and 15 line drawings showing various types of SSC are provided. The amazing array of SSCs from the Galerucinae offers a large and taxonomically diverse set of data that are not comparable with other subfamilies in the Chrysomelidae and may be useful in phylogenetic analysis of the family.
\end{abstract}

\section{Introduction}

Galerucinae (sensu stricto) is the second largest subfamily within the Chrysomelidae (Coleoptera), represented by about 520 genera and between some 5000 species [1], 5500 species [2], and 6300 species [3] and its most diverse distribution concentrated mainly in the tropical and subtropical regions.

The classification of the Chrysomelidae proposed by Lawrence and Newton [4] lumped together the Galerucinae and Alticinae into a single subfamily Galerucinae (sensu lato). Consequently, the Galerucinae (sensu stricto) was placed in the Tribe Galerucini and the Alticinae (sensu stricto) as the Tribe Alticini. Since then, some workers have continued to separate the two subfamilies as in the Seeno and Wilcox [5]. There has been support for Alticinae as a monophyletic group with metafemoral spring as the main character [6]. Likewise, Galerucinae has been considered paraphyletic with Alticinae as a subordinated clade [7]. On the other hand, Kim et al. [8] in their molecular and morphological-based phylogenetic studies showed that there is molecular data to support Alticinae as a tribal ranking (Alticini) within the Galerucinae and neither as a separate subfamily. They suggested that more independent characters are needed. More recently, Gillespie et al. [1] claimed to have the most comprehensive phylogeny estimation and showed consistency with previous molecular phylogenetic reconstruction of Galerucinae, but at the same time agreed that there was a lack of taxon representation from the Old World. There is no doubt that more characteristics need to be utilised from a more complete range of taxa selected from the Old and New Worlds, that is, better taxon sampling, including secondary sexual characteristics.

In this study, we refer to a secondary sexual characteristic (SSC), defined by Mayr [9] as a modified structure of the male members of a species that distinguishes the two sexes of the species but does not function directly in reproduction. The modified structure from the male differs from homologous structures in the female. The SSC may provide an advantage during competition for mates, for example, the aquatic smooth newt, Triturus cristatus [Laurenti] (Amphibia: Salamandridae), is dimorphic with the male having a dorsal crest. Darwin thought that the function of the crest was to attract females, but it was a century later that it was demonstrated that females chose males exhibiting conspicuous dorsal crests [10]. Observational and 
experimental evidence suggest that feather ornaments of birds play an important role in female choice [11]. Eberhard $[12,13]$ referred to an SSC as the nongenitalic male contact structure, a product of an intersexual competition [14]. Besides agreeing that SSCs are the result of Darwinian selection, Jolivet [15] noted that they are also a manifestation of biodiversity.

The SSCs are species specific; thus, they are important as diagnostic tools for identification. In the Chrysomelidae, particularly the subfamily Galerucinae, SSCs are found on various parts of the body, including head, thorax, and abdomen. The presence of these modified characteristics was discussed in some earlier works on the Galerucinae by Maulik [16, 17], who provided illustrations of modified antennae present in some members of the genus Agetocera Hope and modified clypeus in Palpoxena Baly. According to Maulik [17], the antennae, clypeus, labrum, and maxillary palpi that have undergone extraordinary modifications possess a highly diagnostic value. Blake $[18,19]$ noted the modified characteristics, the excised metatibiae of the male, as important generic characters (Deinocladus Blake, Luperosoma Jacoby, and Porechontes Blake). Wilcox [20] noted that in some genera, for example, Malacorhinus Jacoby, species in which the elytra are modified in the male are easily identified by that characteristic. Silfverberg [21] defined Prosmidia Weise and Neolaetana Laboissiere above all by their secondary sexual characteristics, the pronotum, and the basal area of the elytra being modified in the male.

In constructing a phylogeny or a classification, a set of characters from morphological data are tabulated, representing common ancestor (plesiomorphy) and derived states (synapomorphy). The SSC is a derived characteristic. Phylogeny is a statement not only of relationships among taxa but also about the evolution of characters. There is little literature pertaining to the utilization of the SSCs in phylogenetic studies of Chrysomelidae; thus, these characteristics received scant attention. The earliest traceable work was that of Silfverberg [22] in a revision of the galerucine group Prosomidiites, only known from the Afrotropical Region. He employed the modified scutellar area of the elytra as the root for eight genera. Furthermore, according to Silfverberg, the modifications of the male pronotum and elytra are of a type not present in other Galerucinae and can, therefore, be considered apomorphic when found in the Prosomidiites. After more than thirty years, SSCs began to be considered in a phylogenetic analysis. Freund and Wagner [23] constructed a phylogenetic tree of 31 species, which employed 4 SSCs. Barroga and Mohamedsaid [24] in the construction of a phylogeny for genus Aulacophora Chevrolat from Sundaland used 59 characteristics, including 13 SSCs. Recently, Stapel et al. [2] utilized the SSCs from the modified head, antennae, and elytra in their phylogenetic analysis on the Afrotropical Monolepta Chevrolat and related galerucine genera.

The present paper has three objectives: (1) to compile all known of SSCs found in chrysomelid beetles of the subfamily Galerucinae (sensu stricto) from all over the world, (2) to provide some explanation on functions of the various modified structures, and (3) to highlight the myriad forms of
SSCs in the Galerucinae and their taxonomic significance in the Chrysomelidae.

\section{Materials and Methods}

Information sources for SSCs from the subfamily Galerucinae (sensu stricto) were gathered in three ways. Unless otherwise stated, all reference to Galerucinae in this study means sensu stricto. First, male specimens were examined physically for modified structures; second, data was extracted from descriptions and illustrations of modified structure in the literature; third, data was extracted through virtual examination of modified structure displayed on images of the males posted on websites of the Internet. Some of the figures included here were taken directly from websites and, therefore, their clarity and resolution may not be of high quality; however, we feel that they are adequate to illustrate the modifications discussed. For the first phase of this study, the first author examined all the specimens in collection of the Centre for Insect Systematic, Universiti Kebangsaan Malaysia (UKM). Subsequently, three main websites were consulted in the Internet: GBIF Deutschland: http://www.biologie.uniulm.de/; MCZ, Harvard University: http://mcz-28168.oeb .harvard.edu/mcz/index.htm; Smithsonian Institution Library for the digital Biologia Centrali-Americana: http://www .sil.si.edu/DigitalCollections/bca/explore.cfm.

In this study, we decided to exclude modified last visible abdominal sternite (the apical sternite) and modified first segment of protarsi. The SSCs resulting from modifications of these characteristics are universal that are present in most males of the Chrysomelidae although the modified apical sternite is much more complex in Galerucinae (sensu stricto) than in other subfamilies.

\section{Results}

In the course of the present study, the generic names for a number of species are retained because they have not been revised or the revisions are only partially completed. The genus Platyxantha Baly was reduced by Reid [25] to a synonym of Taumacera Thunberg, but this synonymy applies only to species from the Oriental Region. Platyxantha from the African Region has not been revised, and in the present study, 28 species are listed with modified characteristics that possibly belong to another genus than Taumacera. The same is true with Monolepta Chevrolat, where its African fauna has been revised by Wagner [26], but the Oriental and Australasian faunas have not been revised, and we believe some of them could belong to another genus. Therefore, the name Monolepta is retained for 41 species listed here with modified characteristics despite the fact that true Monolepta as redefined by Wagner [27] has no modified characteristics/SSCs. Another genus is Nymphius Weise recently revised by Bezděk [28], but for convenience, the following two species: Calomicrus (Nymphius) buettikeri (Medvedev) and C. (Nymphius) friedmani (Lopatin) with a modified abdomen are retained under Nymphius. This is because the abdomen of these two species has appendages, not a characteristic of the genus Calomicrus Stephens. According to 
TABLE 1: Distribution of modified structures found on head, thorax and abdomen of the chrysomelid beetles subfamily Galerucinae (sensu stricto).

\begin{tabular}{|c|c|}
\hline Head & $\begin{array}{l}\text { Antennae with one, double, and triple seg- } \\
\text { ments, more than three segments modified, } \\
\text { or covered with unusually long hairs. Vertex } \\
\text { depressed or excavated, with surface smooth or } \\
\text { with structures. Frontal tubercles ase very large. } \\
\text { Clypeus is strongly convex, excavated, with } \\
\text { surface smooth, or with structures. Labrum are } \\
\text { extremely large or deformed. Maxillary palpi } \\
\text { with the 3rd segment swollen. Eyes are large. }\end{array}$ \\
\hline \multicolumn{2}{|l|}{ Thorax } \\
\hline Pronotum & $\begin{array}{l}\text { Disc bulged and excavated with structures. } \\
\text { Posterior margin with process. }\end{array}$ \\
\hline Elytra & $\begin{array}{l}\text { Elytra humpback. A pair of tubercles at base or } \\
\text { at apex. A pair of cavities behind scutellum, in } \\
\text { middle, at sides, or at apex. Humeri with rows } \\
\text { of erect hairs. }\end{array}$ \\
\hline Legs & $\begin{array}{l}\text { Front legs: Femora emarginate. Tibiae thick- } \\
\text { ened, curved, emarginated, excised, or notched. } \\
\text { Middle legs: Tibiae curved, excised, or notched. } \\
\text { Hind legs: Trochanters with a process, a spine, } \\
\text { or blade-like structure. Femora enlarged and } \\
\text { excavated. Tibiae broadened, excavated, or } \\
\text { curved; apex of tibiae with a process. All tarsal } \\
\text { claws bifid (simple or appendiculate in female). }\end{array}$ \\
\hline Metasternum & $\begin{array}{l}\text { Metasternum with posterior median lobe or } \\
\text { covered with long hairs. }\end{array}$ \\
\hline Abdomen & $\begin{array}{l}\text { First abdominal sternite with an appendage, a } \\
\text { tubercle, or a pair of appendages, or a projected } \\
\text { covering the following four sternites; first and } \\
\text { second sternites each with a pair of appendages; } \\
\text { second visible sternite with an appendage; third } \\
\text { sternite with one or a pair of long appendages; } \\
\text { fourth sternite emarginated, with a triangular } \\
\text { process, a pair of spines, or long appendages. }\end{array}$ \\
\hline
\end{tabular}

Bezděk, the two species should be placed into a separate new genus. Nevertheless, all these taxonomic changes that would have happened do not affect the total number of modified species from the subfamily Galerucinae and, of course, there would be changes in the total number of genera.

As a result of this study, a list of 172 genera (Appendix A) and 1298 species (Appendix B) of the Galerucinae having SSCs is provided. These SSCs represent various types of modified structures found on all parts of the body head, thorax, and abdomen. Table 1 shows a distribution of various forms of modified structures of the SSCs found on the head, the thorax, and the abdomen. Table 2 shows distribution of the galerucine genera and species with modified head, thorax, and abdomens. Table 3 shows distribution of the galerucine genera and species with various types of modified antennae. Table 4 shows a list of 49 largest genera attributed to the main modified characteristics. Illustrations of 87 selected species, that include images of 84 species and line drawings of 15 species, are provided to show amazing and truly unusual SSCs of the Galerucinae. These SSCs are classified, tabulated,

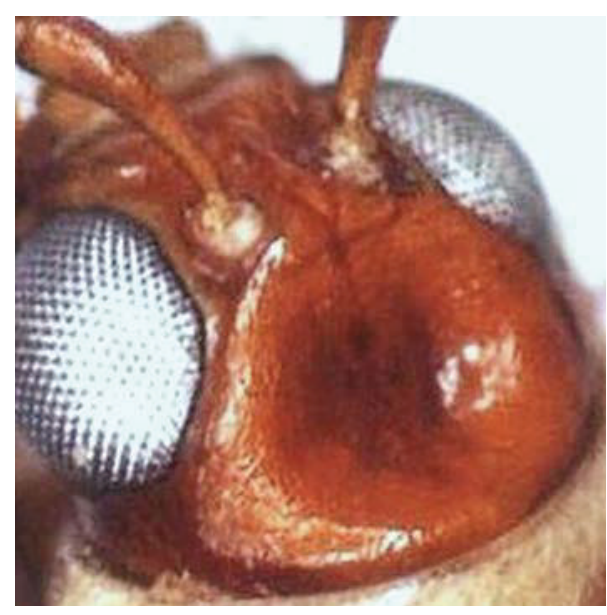

Figure 1: Modified head: Monolepta flavicollis (Gyllenhal).

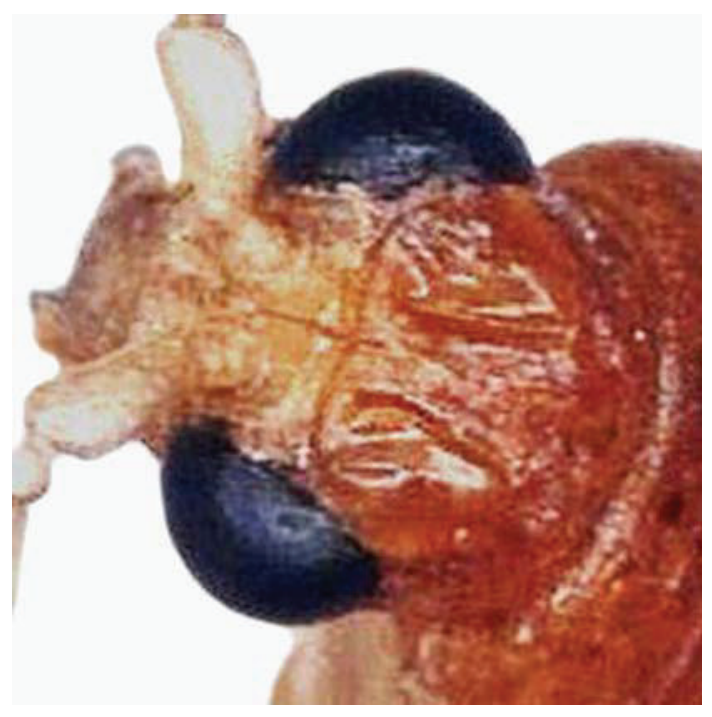

FIgURE 2: Modified head: Aulacophora frontalis Baly.

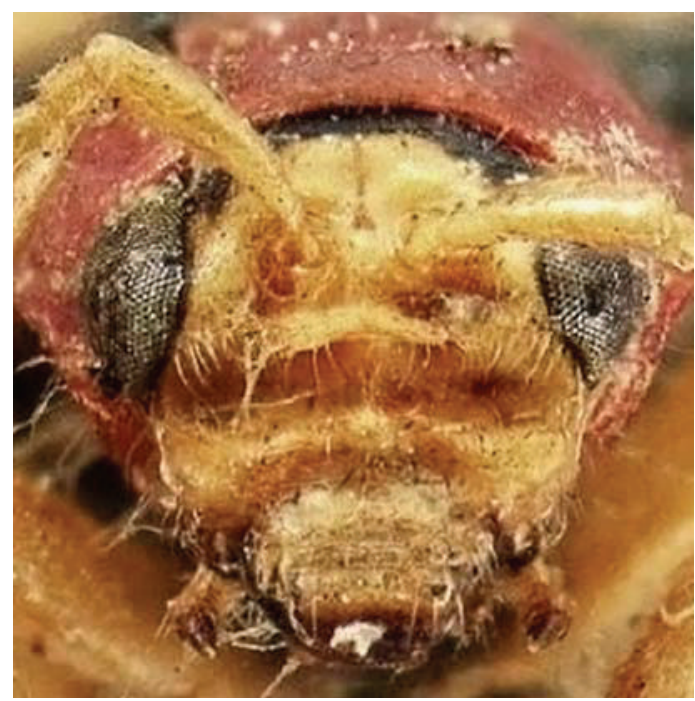

FIgUre 3: Modified head: Cerotoma atrofasciata Jacoby. 
TABLE 2: Distribution of galerucine genera and species with modified head, thorax, and abdomen.

\begin{tabular}{|c|c|}
\hline Modified organs & Genera (number of species) \\
\hline Head & 119 genera (756 species) \\
\hline \multirow[t]{2}{*}{ Vertex } & 10 genera (32 species) \\
\hline & $\begin{array}{l}\text { Aulacophora (12), Chthoneis (1), Coelomera (1), Lamprocopa (10), Malacorhinus (1), Monolepta (1), } \\
\text { Monoleptocrania (1), Oroetes (2), Palpaenidea (2), Sarawakiola (1). }\end{array}$ \\
\hline \multirow[t]{2}{*}{ Frontal tubercles } & 1 genus ( 1 species) \\
\hline & Hyphaenia (1). \\
\hline \multirow[t]{2}{*}{ Clypeus } & 24 genera (181 species) \\
\hline & $\begin{array}{l}\text { Acroxena (5), Afrocrania (5), Aulacophora (1), Azlania (4), Cerotoma (5), Chthoneis (1), Eccoptopsis (12), } \\
\text { Eusattodera (1), Exosoma (1), Fleutiaxia (6), Gynandrobrotica (3), Hoplosaenidea (24), Hyphaenia (6), Hystiopsis } \\
\text { (1), Kanahiiphaga (7), Macrima (9), Metrobrotica (1), Palpoxena (43), Porechontes (3), Pseudaenidea (2), } \\
\text { Rachicephala (1), Sermyloides (31), Taumacera (6), Theopea (3). }\end{array}$ \\
\hline \multirow[t]{2}{*}{ Labrum } & 2 genera (10 species) \\
\hline & Acroxena (1), Palpoxena (9). \\
\hline \multirow[t]{2}{*}{ Maxillary palpi } & 12 genera (51 species) \\
\hline & $\begin{array}{l}\text { Cyclotrypema (1), Aulacophora (5), Cneoranidea (5), Coelomera (1), Diabrotica (5), Gynandrobrotica (3), } \\
\text { Hystiopsis (1), Luperodes (1), Palpaenidea (2), Palpoxena (25), Spilocephalus (1), Theopea (1). }\end{array}$ \\
\hline \multirow[t]{2}{*}{ Eyes } & 12 genera (35 species) \\
\hline & $\begin{array}{l}\text { Aulacophora (2), Cerophysa (1), Chapuisia (8), Chthoneis (1), Diabrotica (12), Haplosomoides (5), Hyphaenia } \\
\text { (1), Liroetis (1), Luperodes (1), Platyxantha (1), Pseudoscelida (1), Rohaniella (1). }\end{array}$ \\
\hline Antennae & 119 genera (645 species) \\
\hline \multirow[t]{2}{*}{ Segments modified } & 109 genera (585 species) \\
\hline & $\begin{array}{l}\text { Acroxena (4), Afrocrania (5), Agetocera (23), Alphidia (1), Anisobrotica (2), Antsianaka (1), Apophylia (17), } \\
\text { Arimetus (2), Arthrotus (1), Asbecesta (20), Aulacophora (53), Austrotella (2), Bangprella (1), Bonesia (2), } \\
\text { Buckibrotica (1), Cerophysa (35), Cerophysella (2), Cerotoma (3), Chapuisia (10), Chthoneis (3), Clitena (2), } \\
\text { Cneorane (1), Coraia (2), Cornubrotica (2), Deinocladus (3), Dercetina (1), Diabrotica (21), Dircemella (1), } \\
\text { Doryscus (1), Dreeus (1), Duvivieria (1), Eccoptopsis (12), Ectmesopus (3), Exosoma (2), Geinula (1), } \\
\text { Halysacantha (1), Haplosomoides (3), Hoplosaenidea (7), Huillania (3), Hylaspoides (1), Hymnesia (1), } \\
\text { Hyphaenia (4), Japonitata (3), Kinabalua (2), Laetana (1), Laetiacantha (10), Leptoxena (1), Lesnella (1), } \\
\text { Liroetiella (1), Luperodes (2), Luperosoma (9), Malacorhinus (5), Megalognatha (59), Metacoryna (5), } \\
\text { Metopoedema (1), Metrobrotica (2), Microlepta (1), Miltina (1), Neolaetana (5), Niasia (3), Nirina (3), } \\
\text { Nirinoides (3), Oidomorpha (1), Oorlogia (1), Ornithonagthus (1), Oroetes (2), Orthoxia (1), Palpaenidea (1), } \\
\text { Palpoxena (6), Parabrotica (1), Paraplotes (3), Parabescesta (6), Paratriarius (2), Periclitena (2), Phyllecthris (3), } \\
\text { Phyllobrotica (1), Phyllobroticella (7), Pimentelia (1), Platybrotica (1), Platyxantha (19), Porechontes (2), } \\
\text { Pseudorupilia (2), Pseudoshaira (1), Pseudoscelida (2), Rohaniella (1), Ruwenzoria (1), Samoria (7), Sarawakiola } \\
\text { (1), Schematiza (5), Sermyloides (26), Sessilia (1), Shungwayana (1), Sikkimia (4), Simopsis (1), Spilocephalus } \\
\text { (3), Spilonotella (1), Stenoplatys (2), Synetocephalus (1), Taenala (2), Taphinella (1), Taumacera (41), } \\
\text { Taumaceroides (1), Theopea (5), Therphis (1), Trichomimastra (1), Vitruvia (1), Xenarthra (6), Xenoda (23), } \\
\text { Zinjotella (1). }\end{array}$ \\
\hline \multirow[t]{2}{*}{ With 10 segments } & 2 genera ( 5 species $)$ \\
\hline & Oroetes (2), Phyllecthris (3) \\
\hline \multirow[t]{2}{*}{ With long hairs } & 19 genera ( 55 species) \\
\hline & $\begin{array}{l}\text { Acroxena (1), Aelianus (1), Apophylia (1), Arthrotus (1), Aulacophora (2), Cerophysa (1), Cerophysella (1), } \\
\text { Chthoneis (1), Dimalianella (2), Eleona (1), Haplosomoides (1), Hyphaenia (21), Leptaulaca (5), Mahutia (1), } \\
\text { Mimastra (1), Platyxantha (7), Pseudoscelida (2), Sinoluperoides (1), Stenellina (4). }\end{array}$ \\
\hline Thorax & 37 genera (379 species) \\
\hline Pronotum & 10 genera (38 species) \\
\hline \multirow[t]{2}{*}{ With tubercles } & 4 genera ( 17 species $)$ \\
\hline & Bacteriaspis (2), Cannonia (4), Paracanthina (2), Prosmidia (9). \\
\hline \multirow[t]{2}{*}{ With cavities } & 5 genera $(19$ species $)$ \\
\hline & Jacobya (5), Laetiacantha (9), Neolaetana (3), Oroetes (1), Paleosepharia (1). \\
\hline \multirow[t]{2}{*}{ Posterior process } & 5 genera (22 species) \\
\hline & Cannonia (4), Laetiacantha (6), Paleosepharia (1), Prosmidia (9), Taenala (2). \\
\hline Scutellum tongue-shaped & Prosmidia (3). \\
\hline
\end{tabular}


TABle 2: Continued.

\begin{tabular}{|c|c|}
\hline Modified organs & Genera (number of species) \\
\hline Elytra & 30 genera (304 species) \\
\hline \multirow[t]{2}{*}{ With tubercles } & 10 genera (119 species) \\
\hline & $\begin{array}{l}\text { Bacteriaspis (2), Cannonia (2), Diacantha (81), Elyces (1), Halysacantha (1), Laetiacantha (10), Lesnella (1), } \\
\text { Paracanthina (2), Prosmidia (18), Sonchia (1). }\end{array}$ \\
\hline \multirow[t]{2}{*}{ With cavities } & 19 genera (180 species) \\
\hline & $\begin{array}{l}\text { Afroatrachya (1), Afrocrania (10), Androlyperus (6), Atrachya (5), Austrotella (2), Candezea (8), Cerophysella (2), } \\
\text { Erythrobapta (1), Lomirana (1), Malacorhinus (8), Monolepta (30), Neolaetana (5), Paleosepharia (44), } \\
\text { Paratriarius (8), Paridea (15), Phyllobroticella (7), Pseudocophora (25), Pseudocrania (2), Strobiderus (1). }\end{array}$ \\
\hline Humeral hairs & Aulacophora (5). \\
\hline \multirow[t]{2}{*}{ Metasternum } & 4 genera (60 species) \\
\hline & Apophylia (12), Cneoranidea (1), Kinabalua (2), Taumacera (45). \\
\hline Legs & 88 genera (401 species) \\
\hline Hind trochanter & Coeligetes (1), Liroetis (1), Monolepta (1). \\
\hline Front femora & Lygistus (1), Mahutia (1), Taumaceroides (1). \\
\hline Middle femora & Cornibrotica (1), Mahutia (1). \\
\hline Hind femora & Mahutia (1), Leptoxena (1), Apophylia (3). \\
\hline Front tibiae & $\begin{array}{l}\text { Cornubrotica (1), Cyclotrypema (1), Eccoptopsis (1), Eleona (1), Hoplosaenidea (1), Hystiopsis (3), Leptaulaca (1), } \\
\text { Metrobrotica (1), Mombasa (3), Parabrotica (1), Platymorpha (2), Platyxantha (1), Simopsis (1), Stenoplatys (1), } \\
\text { Synetocephalus (1), Luperosoma (9), Taumacera (2), Taumaceroides (1). }\end{array}$ \\
\hline Middle tibiae & $\begin{array}{l}\text { Coraia (2), Cornubrotica (1), Deinocladus (3), Dreeus (1), Ephaenidea (1), Haplosomoides (1), Momaea (1), } \\
\text { Oroetes (1), Parabrotica (1), Phyllecthris (3), Platymorpha (1), Porechontes (3), Simopsis (1), Synetocephalus (1), } \\
\text { Taumacera (2), Trichobrotica (9). }\end{array}$ \\
\hline Hind tibiae & $\begin{array}{l}\text { Apophylia (2), Cerophysa (1), Duvivieria (1), Haplosomoides (1), Hoplasoma (1), Hoplosaenidea (3), Lilophaea } \\
\text { (1), Luperodes (1), Platyxantha (2), Scelida (1), Scelidacne (1), Scelolyperus (15), Synetocephalus (1), Taumacera } \\
\text { (11). }\end{array}$ \\
\hline \multirow[t]{2}{*}{ Tarsal claws bifid } & 2 genera ( 153 species $)$ \\
\hline & Apophylia (148), Erynephala (5) \\
\hline \multirow[t]{2}{*}{ Abdomen } & 18 genera (66 species) \\
\hline & $\begin{array}{l}\text { Anatela (1), Androlyperus (1), Apophylia (6), Cneoranidea (1), Ceoligetes (2), Euliroetis (5), Haplosomoides (13), } \\
\text { Hemigascelis (1), Hoplasoma (13), Inbioluperus (1), Liroetis (2), Luperogala (2), Mimastra (2), Nymphius (9), } \\
\text { Phyllobrotica (4), Pseudoluperus (1), Scelida (1), Scelidacne (1). }\end{array}$ \\
\hline
\end{tabular}

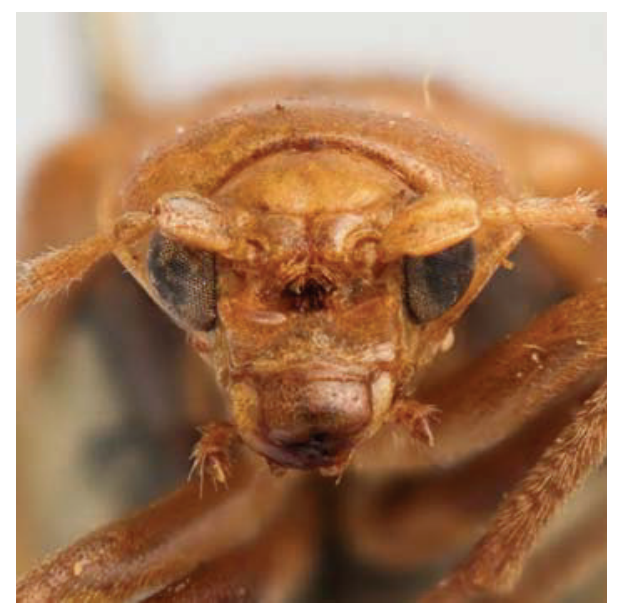

(a)

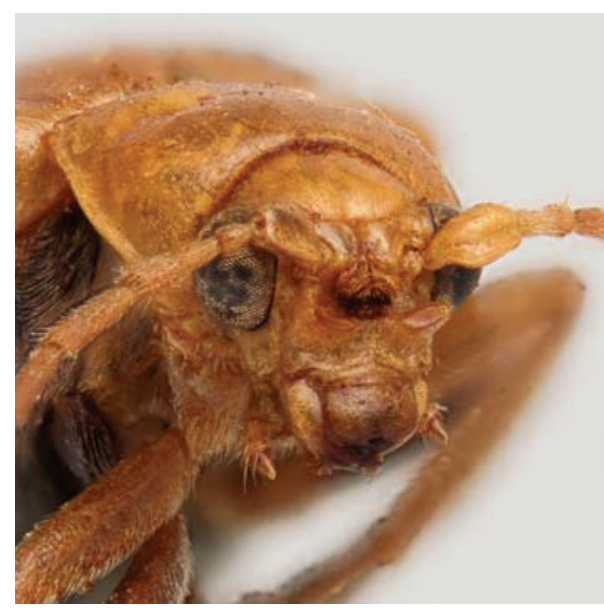

(b)

Figure 4: Modified head: Aulacophora cornuta Baly. 
TABLE 3: Distribution of galerucine genera and species with various types of modified antennal segments.

\begin{tabular}{|c|c|}
\hline Modified segments & Genera (number of species) \\
\hline Single & 41 genera and 156 species \\
\hline 1 st & $\begin{array}{l}9 \text { genera and } 21 \text { species: Antsianaka (1), Aulacophora (8), Doryscus (1), Hoplosaenidea (4), Malacorhinus (2), } \\
\text { Metopoedema (1), Palpoxena (1), Paraplotes (1), Sarawakiola (1). }\end{array}$ \\
\hline $3 \mathrm{rd}$ & $\begin{array}{l}9 \text { genera and } 40 \text { species: Arthrotus (1), Aulacophora (1), Halysacantha (1), Hylaspoides (1), Metrobrotica (1), } \\
\text { Microlepta (1), Palpoxena (1), Sermyloides (26), Taumacera (16). }\end{array}$ \\
\hline 4 th & $\begin{array}{l}7 \text { genera } 12 \text { species: Afrocrania (4), Cerophysa (2), Geinula (1), Hoplosaenidea (1), Hyphaenia (1), Luperodes } \\
\text { (2), Palpaenidea (1). }\end{array}$ \\
\hline 5 th & 1 genus and 4 species: Apophylia (4). \\
\hline 7th & $\begin{array}{l}6 \text { genera } 24 \text { species: Bangprella (1), Dercetina (1), Duvivieria (1), Megalognatha (19), Oidomorpha (1), } \\
\text { Palpoxena (1), Ruwenzoria (1). }\end{array}$ \\
\hline 8th & $\begin{array}{l}8 \text { genera and } 23 \text { species: Clitena (1), Hymnesia (1), Apophylia (1), Cerophysa (15), Dircemella (1), Metacoryna } \\
\text { (1), Periclitena (2), Pseudoscelida (1). }\end{array}$ \\
\hline 9th & 5 genera and 8 species: Agetocera (4), Cerophysa (1), Metacoryna (1), Periclitena (1), Porechontes (1). \\
\hline 10 th & 1 genus and 2 species: Ectmesopus (2). \\
\hline 11th & 4 genera and 12 species: Aulacophora (7), Luperosoma (3), Paraplotes (1), Phyllobrotica (1). \\
\hline Double & 27 genera and 106 species \\
\hline 1st and 3rd & 2 genera and 3 species: Acroxena (2), Taumacera (1). \\
\hline 3rd and 4th & $\begin{array}{l}12 \text { genera and } 36 \text { species: Apophylia (1), Cerophysa (2), Cerotoma (3), Eccoptopsis (12), Hoplosaenidea (2), } \\
\text { Laetana (1), Liroetiella (1), Malacorhinus (1), Metrobrotica (1), Oroetes (2), Phyllobroticella (7), Taumacera (3). }\end{array}$ \\
\hline 3rd and 8th & 1 genus and 1 species: Taumacera (2). \\
\hline 4th and 5th & 1 genus and 1 species: Afrocrania (1). \\
\hline 5th and 6th & 2 genera and 2 species: Taumacera (1), Taumaceroides (1). \\
\hline 6th and 7 th & 3 genera and 11 species: Cerophysa (6), Megalognatha (4), Taumacera (1). \\
\hline 7th and 8th & 2 genera and 6 species: Kinabalua (2), Megalognatha (4). \\
\hline 7th and 9th & 1 genus and 1 species: Buckibrotica (1). \\
\hline 8th and 9th & $\begin{array}{l}7 \text { genera and } 29 \text { species: Agetocera (19), Cornubrotica (2), Hyphaenia (1), Megalognatha (2), Metacoryna (3), } \\
\text { Nirina (1), Taumacera (1). }\end{array}$ \\
\hline 9th and 10th & 4 genera and 8 species: Hyphaenia (1), Luperosoma (1), Stenoplatys (1), Taumacera (5). \\
\hline 9th and 11 th & 1 genus and 1 species: Dreeus (1). \\
\hline 10th and 11th & 3 genera and 6 species: Platyxantha (1), Sikkimia (4), Taumacera (1). \\
\hline Triple & 21 genera and 97 species \\
\hline $3 \mathrm{rd}, 4 \mathrm{th}$, and 5 th & 3 genera and 36 species: Acroxena (1), Aulacophora (34), Cerophysa (1). \\
\hline 3 rd, 6th, and 7th & 1 genus and 1 species: Taumacera (1). \\
\hline 3rd, 8th, and 9th & 2 genera and 3 species: Porechontes (1), Taumacera (2). \\
\hline 4 th, 5 th, and 6 th & 2 genera and 3 species: Cerophysa (2), Chthoneis (1). \\
\hline 5 th, 6 th, and 7 th & 2 genera and 2 species: Paratriarius (1), Platyxantha (1). \\
\hline 6 th, 7 th, and 8 th & 3 genera and 16 species: Asbecesta (1), Cerophysa (2), Megalognatha (13). \\
\hline 6 th, 9th, and 10th & 1 genus and 1 species: Taumacera (1). \\
\hline 7th, 8th, and 9th & 3 genera and 13 species: Asbecesta (4), Megalognatha (8), Paratriarius (1). \\
\hline 8th, 9th, and 10th & 4 genera and 4 species: Asbecesta (1), Eccoptopsis (1), Hoplasoma (1), Trichomimastra (1). \\
\hline 9 th, 10th, and 11th & $\begin{array}{l}9 \text { genera and } 20 \text { species: Anisobrotica (2), Apophylia (5), Cneorane (1), Japonitata (1), Leptoxena (1), } \\
\text { Luperosoma (3), Stenoplatys (1), Taumacera (5), Vitruvia (1). }\end{array}$ \\
\hline \multirow[t]{2}{*}{$\begin{array}{l}\text { More than three } \\
\text { segments modified }\end{array}$} & 71 genera and 232 species \\
\hline & $\begin{array}{l}\text { Acroxena (1), Agetocera (1), Apophylia (6), Arimetus (2), Arthrotus (1), Asbecesta (14), Aulacophora (5), } \\
\text { Austrotella (2), Bonesia (2), Buckbrotica (1), Cerophysa (6), Cerophysella (1), Chapuisia (10), Chthoneis (3), } \\
\text { Clitena (1), Cneorane (1), Coraia (2), Deinocladus (3), Diabrotica (21), Ectmesopus (1), Exosoma (2), } \\
\text { Haplosomoides (3), Huillania (3), Hyphaenia (1), Jacobya (1), Japonitata (2), Laetana (1), Laetiacantha (10), } \\
\text { Lesnella (1), Luperosoma (2), Malacorhinus (2), Megalognatha (4), Miltina (1), Neolaetana (5), Niasia (3), } \\
\text { Nirina (2), Nirinoides (3), Oorlogia (1), Ornithognathus (1), Orthoxia (1), Palpoxena (2), Parabrotica (1), } \\
\text { Paraplotes (2), Parasbecesta (6), Paratriarius (2), Pimentelia (1), Platybrotica (1), Platyxantha (16), Pseudorupilia } \\
\text { (2), Pseudoscelida (1), Pseudoshaira (1), Rohaniella (1), Ruwenzoria (1), Samoria (7), Schematiza (5), Sessilia (1), } \\
\text { Shungwayana (1), Simopsis (1), Spilocephalus (2), Spilonotella (1), Stenoplatys (1), Synetocephalus (1), Taenala } \\
\text { (1), Taphinella (1), Taumacera (3), Theopea (5), Therpis (1), Trichomimastra (1), Xenarthra (6), Xenoda (23). }\end{array}$ \\
\hline
\end{tabular}


TABLE 4: List of 49 largest genera with common modified organs.

\begin{tabular}{|c|c|c|}
\hline Genera & No. of species & Common modified organs \\
\hline (1) Apophylia & 148 & Tarsal claws bifid \\
\hline (2) Diacantha & 81 & Elytra tuberculate \\
\hline (3) Megalognatha & 59 & Antennal segments modified \\
\hline (4) Aulacophora & 54 & Antennal segments modified \\
\hline (5) Taumacera & 45 & $\begin{array}{l}\text { Metasternum with posterior } \\
\text { process }\end{array}$ \\
\hline (6) Paleosepharia & 44 & Elytra excavated \\
\hline (7) Palpoxena & 41 & Head excavated \\
\hline (8) Cerophysa & 33 & Antennal segments modified \\
\hline (9) Monolepta & 31 & Elytra excavated \\
\hline (10) Sermyloides & 31 & Head excavated \\
\hline (11) Pseudocophora & 25 & Elytra excavated \\
\hline (12) Hoplosaenidea & 24 & Head excavated \\
\hline (13) Hyphaenia & 24 & Antennae with long hairs \\
\hline (14) Xenoda & 23 & Antennal segments modified \\
\hline (15) Agetocera & 22 & Antennal segments modified \\
\hline (16) Diabrotica & 21 & Antennal segments modified \\
\hline (17) Asbecesta & 20 & Antennal segments modified \\
\hline (18) Prosmidia & 18 & Elytra tuberculate \\
\hline (19) Platyxantha & 17 & Antennal segments modified \\
\hline (20) Paridea & 15 & Elytra excavated \\
\hline (21) Hoplasoma & 13 & Abdomen with appendages \\
\hline (22) Diabrotica & 13 & Eyes large \\
\hline (23) Eccoptopsis & 12 & Antennal segments modified \\
\hline (24) Afrocandezea & 11 & Elytra excavated \\
\hline (25) Haplosomoides & 11 & Abdomen with appendages \\
\hline (26) Lamprocopa & 10 & Head excavated \\
\hline (27) Laetiacantha & 10 & Elytra tuberculate \\
\hline (28) Afrocrania & 10 & Elytra excavated \\
\hline (29) Scelolyperus & 10 & Hind tibiae curved \\
\hline (30) Macrima & 9 & Head excavated \\
\hline (31) Nymphius & 9 & Abdomen with appendages \\
\hline (32) Luperosoma & 9 & Middle tibiae notched \\
\hline (33) Trichobrotica & 9 & Middle tibiae notched \\
\hline (34) Malacorhinus & 8 & Elytra excavated \\
\hline (35) Candezea & 8 & Elytra excavated \\
\hline (36) Chapuisia & 8 & Eyes large \\
\hline (37) Kanahiiphaga & 7 & Head excavated \\
\hline (38) Phyllobroticella & 7 & Antennal segments modified \\
\hline (39) Samoria & 7 & Antennal segments modified \\
\hline (40) Fleutiauxia & 6 & Head excavated \\
\hline (41) Parabecesta & 6 & Antennal segments modified \\
\hline (42) Metacoryna & 5 & Antennal segments modified \\
\hline (43) Schematiza & 5 & Antennal segments modified \\
\hline (44) Theopea & 5 & Antennal segments modified \\
\hline (45) Cneoranidea & 5 & Maxillary palpi large \\
\hline (46) Atrachya & 5 & Elytra excavated \\
\hline (47) Neolaetana & 5 & Elytra excavated \\
\hline (48) Euliroetis & 5 & Abdomen with appendages \\
\hline (49) Jacobya & 5 & Pronotum excavated \\
\hline
\end{tabular}

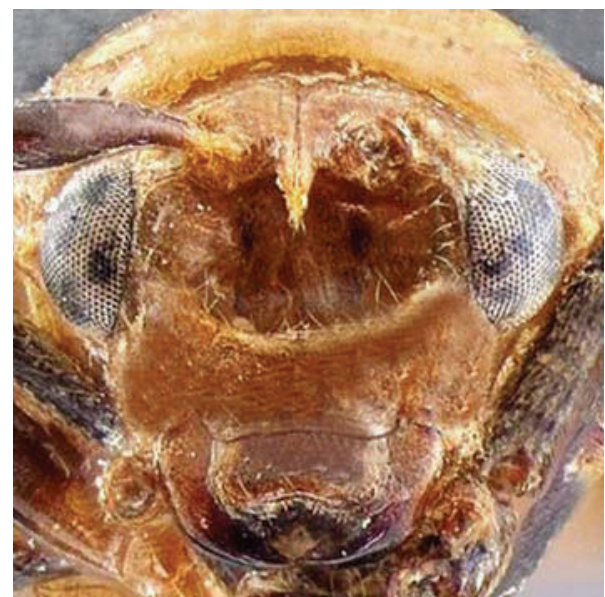

Figure 5: Modified head: Palpoxena divisa (Jacoby).

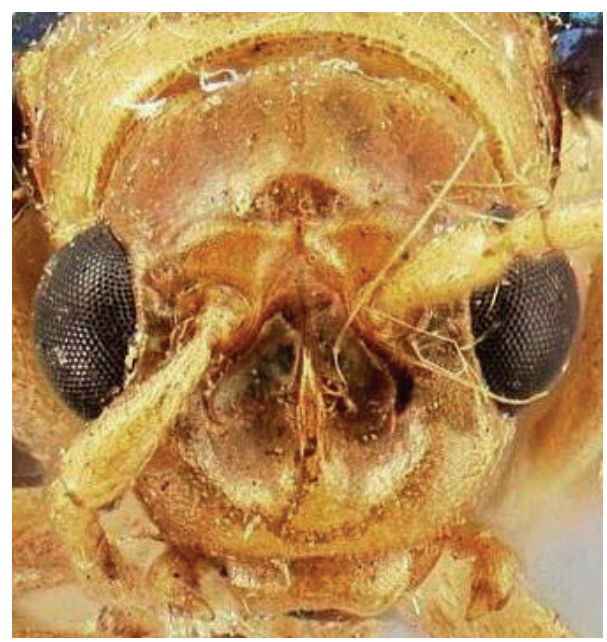

Figure 6: Modified head: Palpoxena sumatrensis (Jacoby).

and provided with plausible explanations of their functions. However, it is beyond the scope of the present study to go into a detailed anatomy of the various modified structures.

Every part of the body, including the head, thorax, and abdomen, is affected with some forms of modifications (Tables 1, 2, and 3). Table 1 shows various modified structures present on the head, thorax, and abdomen. On the head, almost every aspect has a structure that has undergone modification, including vertex, frontal tubercles, clypeus, labrum, maxillary palpi, eye, and antenna. Table 2 shows distribution of galerucine genera and species with the modified structures. Modifications of head structures are found in 756 species and 119 genera. These modified structures can be described as simple to complex. The simple modified vertex has a smoothly bulged surface, or smoothly, strongly depressed surface (Monolepta flavicollis (Gyllenhal) (Figure 1)). The complex modified vertex has a depressed or excavated area with ridges or other structures (Aulacophora frontalis Baly (Figure 2)). 


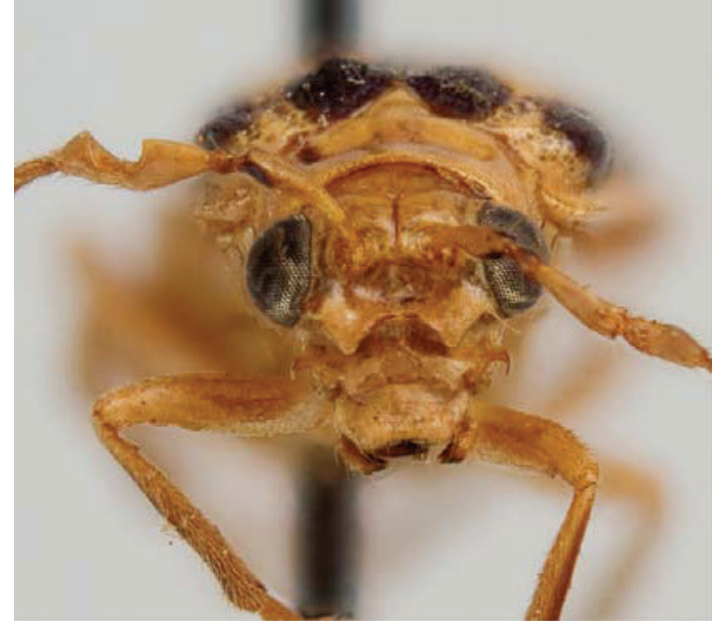

(a)

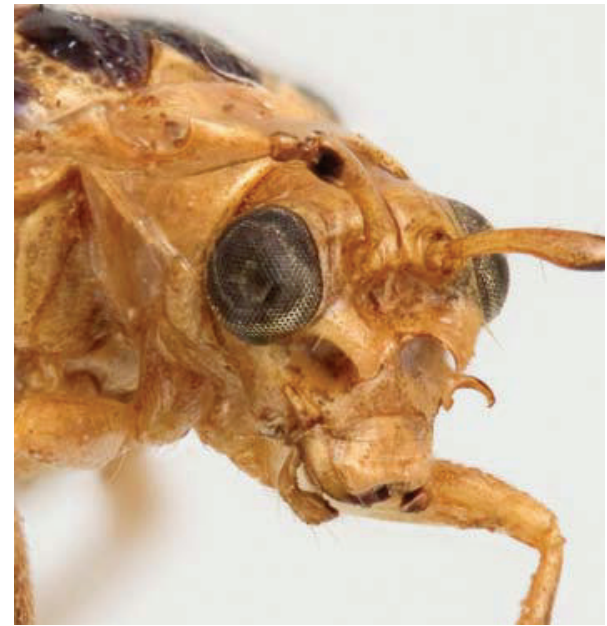

(b)

Figure 7: Modified head: Eccoptopsis denticornis (Jacoby).

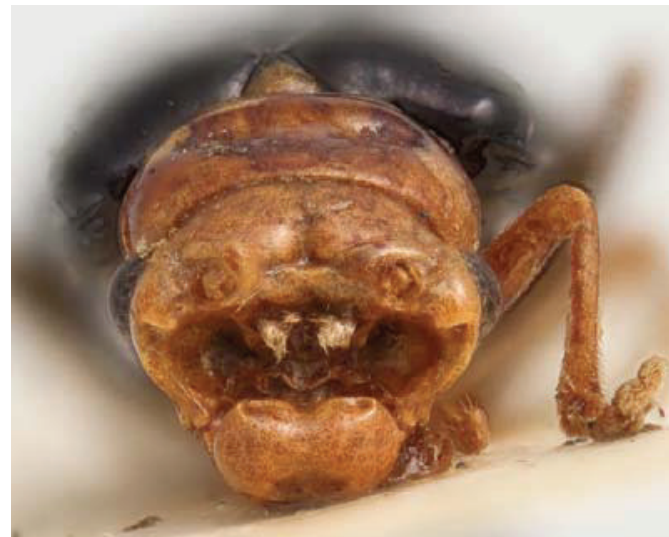

(a)

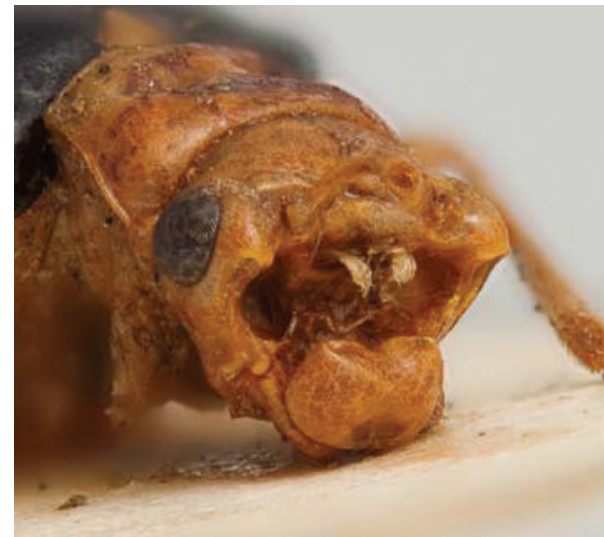

(b)

Figure 8: Modified labrum: Palpoxena barbata (Baly).

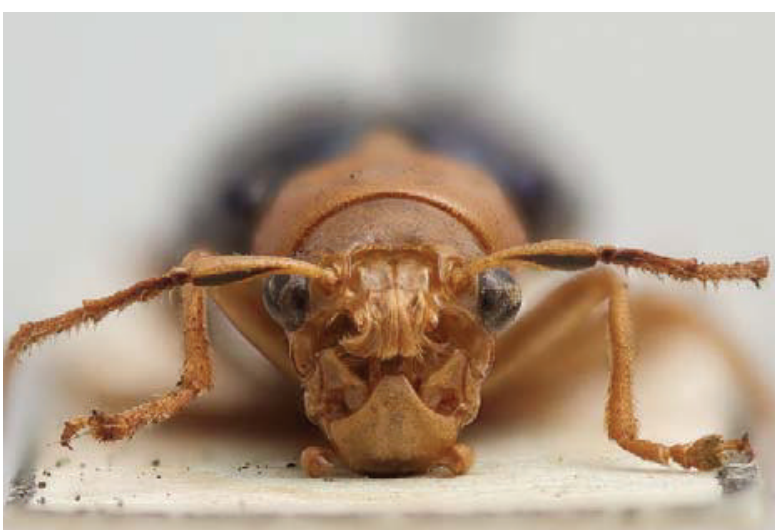

(a)

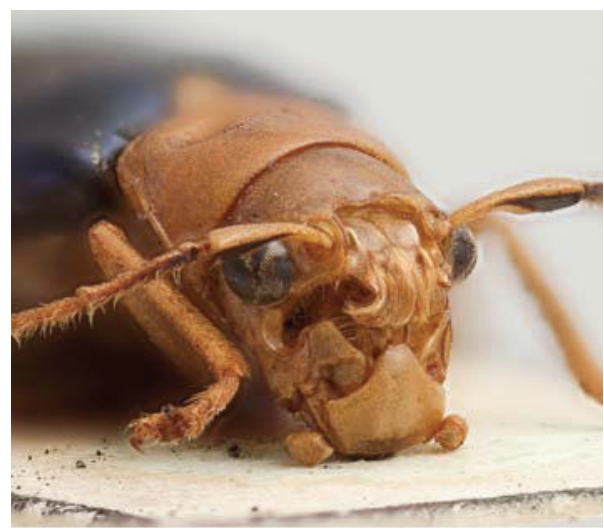

(b)

Figure 9: Modified labrum: Palpoxena coeruleipennis (Baly). 


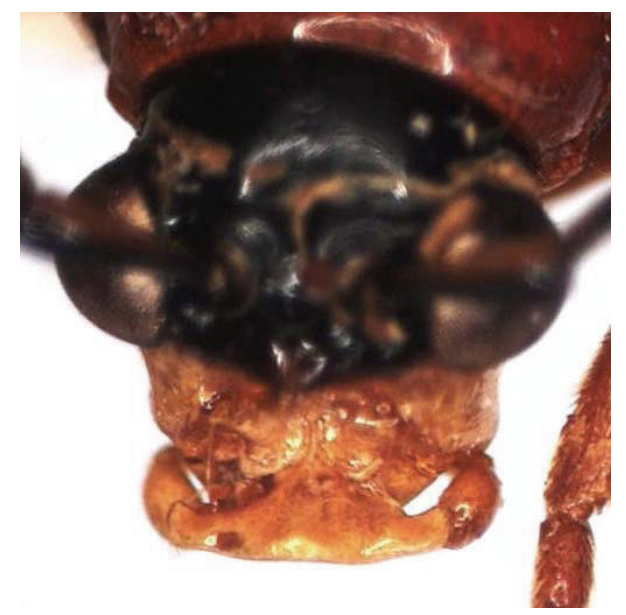

FIgUre 10: Modified labrum: Palpoxena variabilis (Jacoby).

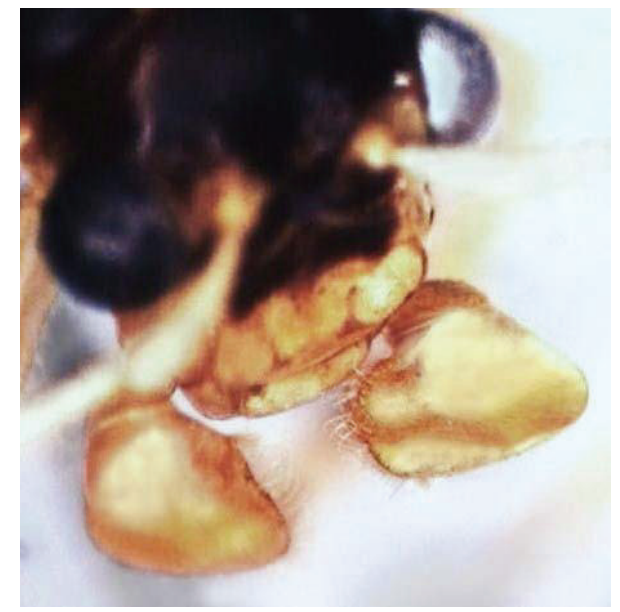

FIgURE 11: Modified maxillary palpi of Palpoxena laeta (Baly).

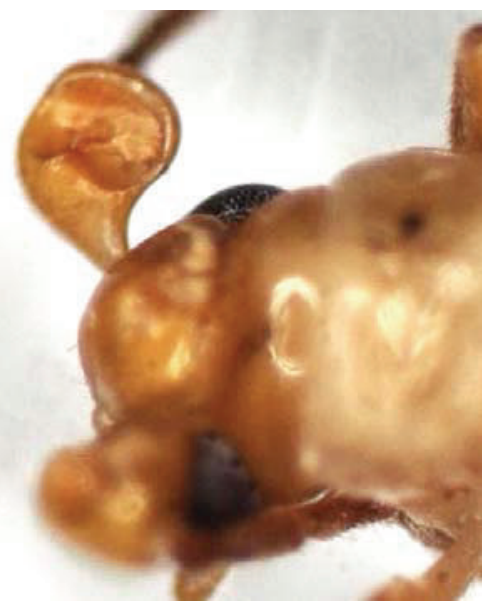

FIGURE 12: Modified antennae: Sarawakiola ajaib Mohamedsaid.

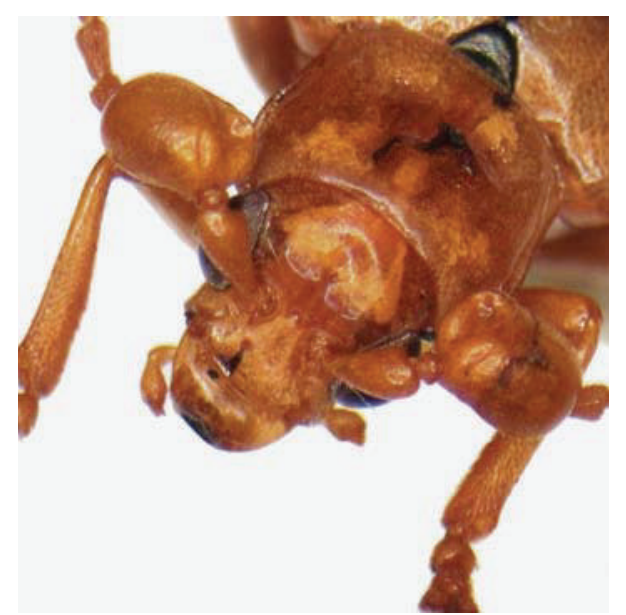

Figure 13: Modified antennae: Taumacera sucki (Weise).

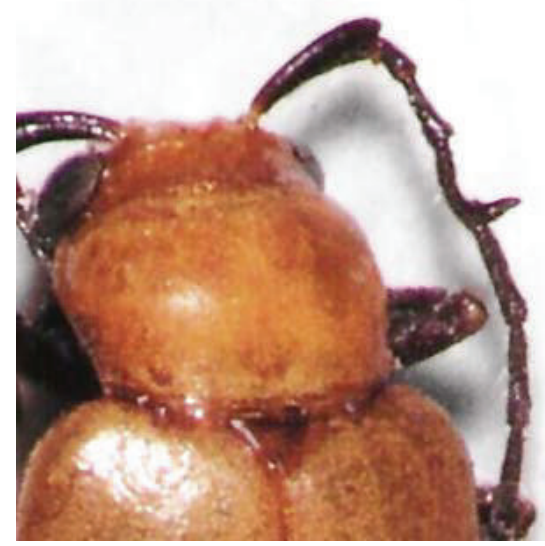

FIGURE 14: Modified antennae: Afrocrania kaethae Middelhauve and Wagner.

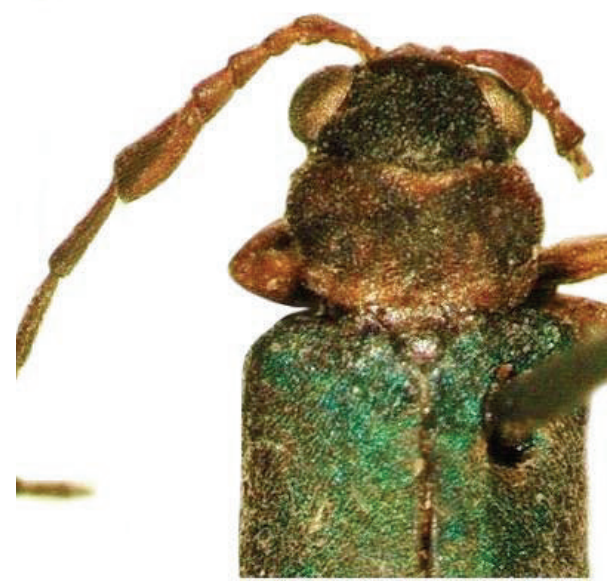

Figure 15: Modified antennae: Apophylia incisitarsis (Laboissiere). 


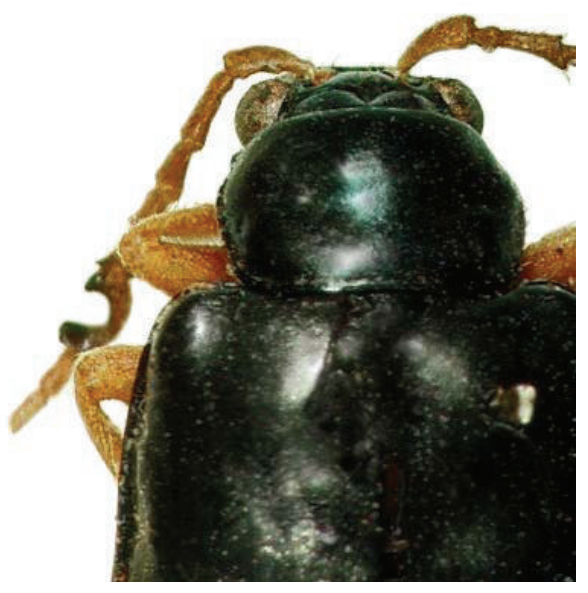

FIgURE 16: Modified antennae: Duviviera apicitarsis Weise.

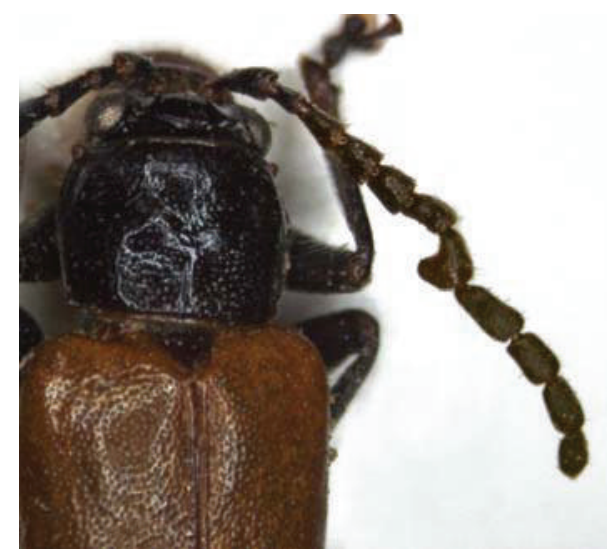

FIgUre 17: Modified antennae: Megalognatha grouvellei Weise.

The clypeus is located anterior to the frontal tubercles. The modified clypeus is found in 181 species and 24 genera (Table 2). The genus Palpoxena Baly has the highest number of modified clypeus, represented by 43 species. A simple modified clypeus has its surface transversely, deeply depressed and without structures (Cerotoma atrofasciata Jacoby (Figure 3)). A complex one has some forms of structures, such as ridges, projections, and hairs. In Aulacophora cornuta Baly (Figures 4(a) and 4(b)), the clypeus is deeply excavated anteriorly and with a process at sides. In an extreme case, the modified clypeus is deformed or disfigured (Palpoxena divisa (Jacoby) (Figure 5), P. sumatrensis (Jacoby) (Figure 6), and Eccoptopsis denticornis (Jacoby) (Figures 7(a) and $7(\mathrm{~b}))$ ). Mouthparts affected with modifications are labrum and maxillary palpi. Modified labrum in form of extremely large size is found in two genera, Acroxena Baly and Palpoxena Baly. The labrum is either transverse ( $P$. barbata (Baly) (Figures $8(\mathrm{a})$ and $8(\mathrm{~b}))$ ) or triangularly shaped $(P$. coeruleipennis (Baly) (Figure 9) and P. variabilis (Jacoby) (Figure 10)). Maxillary palpi with modification are quite common, and they are found in 51 species and 12 genera. In some species the modification is very extreme and the usually

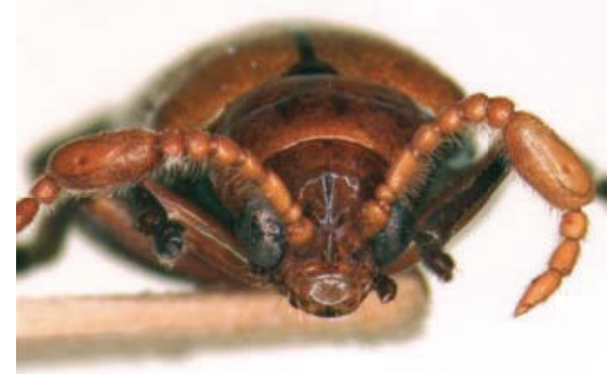

FIgUre 18: Modified antennae: Cerophysa flava Baly.

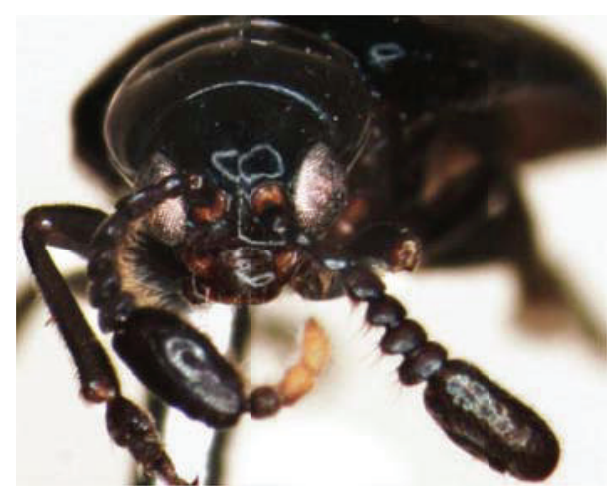

Figure 19: Modified antennae: Cerophya gestroi Jacoby.

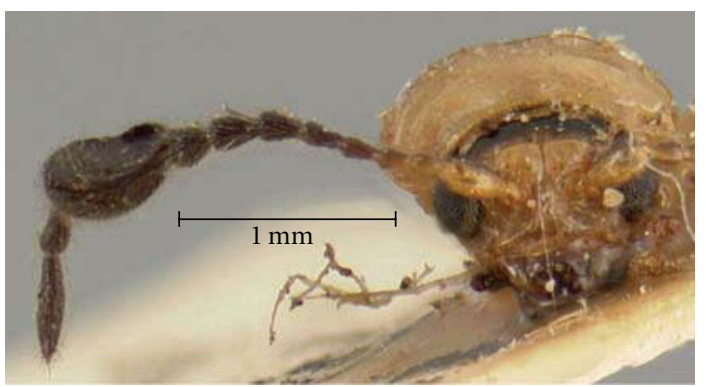

FIgUre 20: Modified antennae: Metacoryna guatemalensis Jacoby.

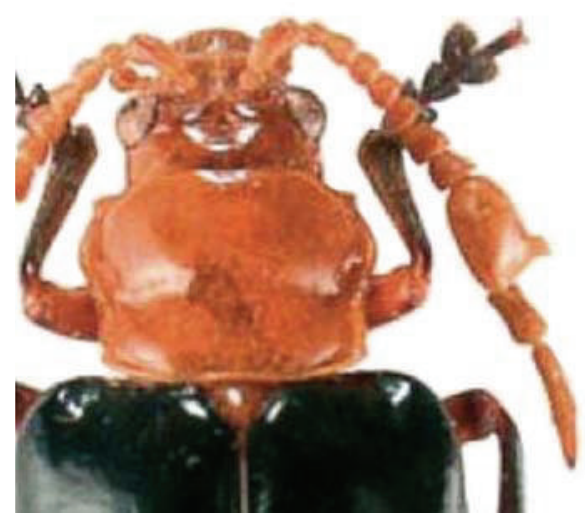

FIgure 21: Modified antennae: Agetocera silva Bezděk. 


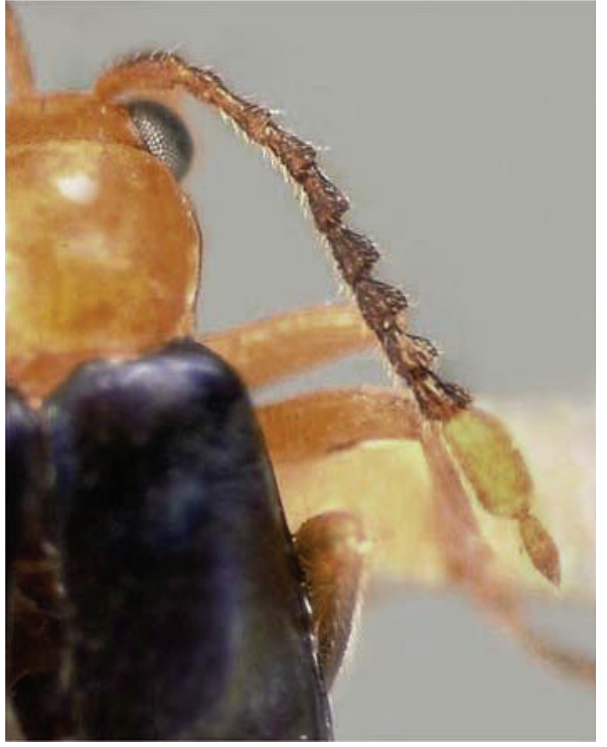

FIgURE 22: Modified antennae: Ectmesopus darlingtoni Blake.

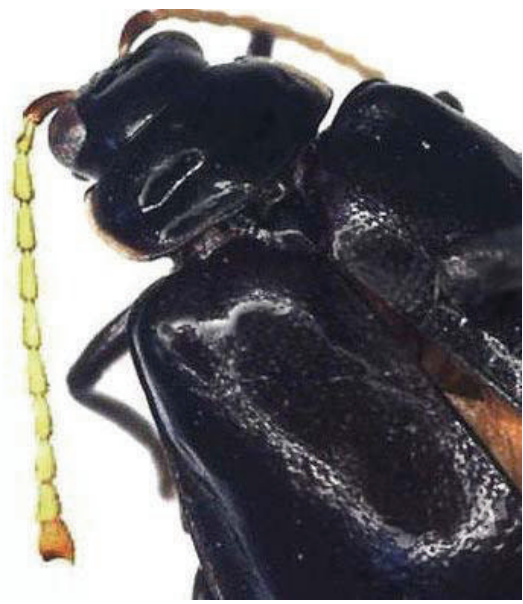

FIGURE 23: Modified antennae: Aulacophora luteicornis (Fabricius).

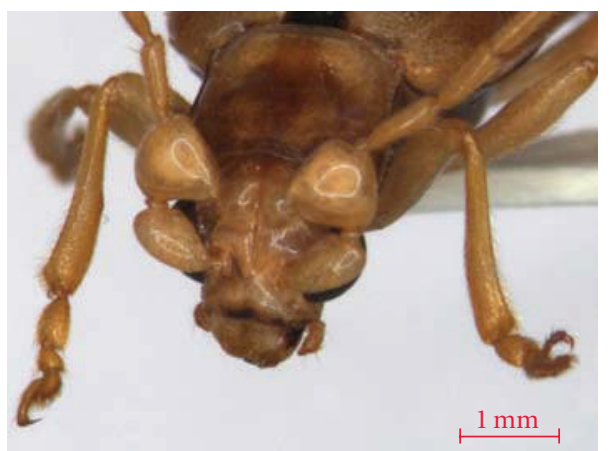

FIGURE 24: Modified antennae: Taumacera khalednordini Mohamedsaid.

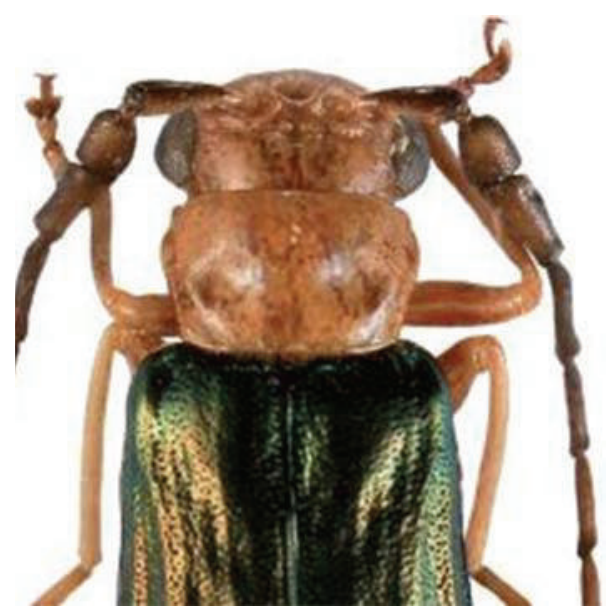

Figure 25: Modified antennae: Hoplosaenidea aerosa (Laboissiere).

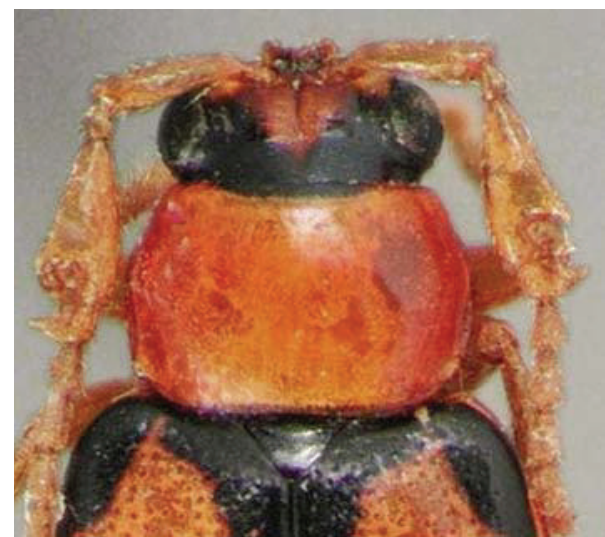

Figure 26: Modified antennae: Cerotoma ruficornis (Olivier).

cylindrical-shaped of the palpi is deformed (Palpoxena laeta (Baly) (Figure 11)). Males with large size of eyes are found in 35 species and 12 genera (Table 2 ).

The modified antennae are the most widely distributed, found in 645 species and 119 genera (Table 2). The number of species with modified antenna amounts to $50 \%$ of the total modified Galerucinae. The genus Megalognatha Baly has the highest number with modified antenna, represented by 59 species. Generally, all males and females have 11 antennal segments. However, in the following two genera, Oroetes Jacoby and Phyllecthris Dejean, the male has the antenna with 10 segments compared with 11 in females. Every antennal segment, from the first to the eleventh, is affected by some form of modification. A simple modification is an enlargement of a segment, without any cavity, structure, or gland. A complex one affects more than one segment. Besides, some of the modified segments appear totally different from normal feature, being distorted or deformed.

Table 3 shows distribution of galerucine genera and species with various types of modified antenna. There are examples of sets of single, double, triple, and more than three 


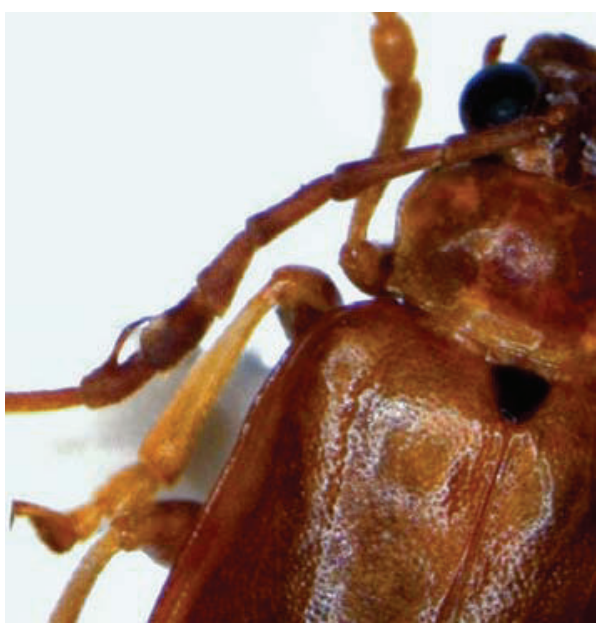

(a)

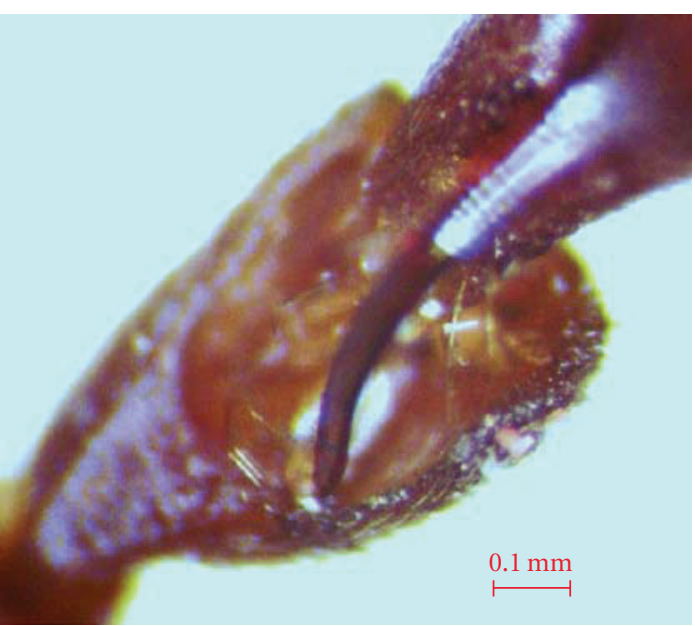

(b)

Figure 27: Modified antennae: Kinabalua musaamani Mohamedsaid.

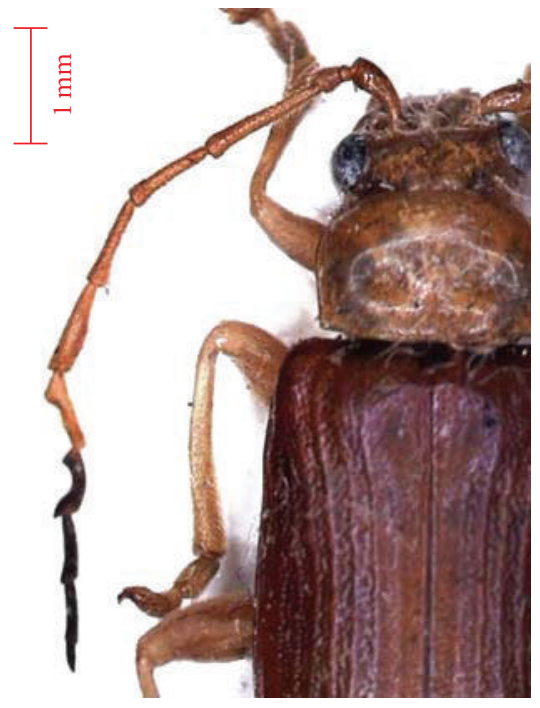

FIGURE 28: Modified antennae: Taumacera occipitalis (Laboissiere).

modified segments. Antennal segment 2 is rarely modified but always reduced to a minute size if segment 3 is greatly modified, as in Taumacera spp. However, in Aulacophora diversa Baly and A. dulitensis Barroga and Mohamedsaid, segment 2 is enlarged and dilated at apex and modified together with segments $3-7$. The same is with segment 6 that is never singularly modified but always combined with other segments, such as in the double modified segments 5 and 6 (Taumaceroides sinicus Lopatin) and segments 6 and 7 (Taumacera variceps (Laboissiere); and in the triple modified segments 5, 6, and 7 (Paratriarius dorsatus (Say), and segments 6, 7, and 8 (Megalognatha roletti Laboissiere (Figure 34)).

There are 156 species in 41 genera having a single modified antennal segment. Segment 3 is the most affected

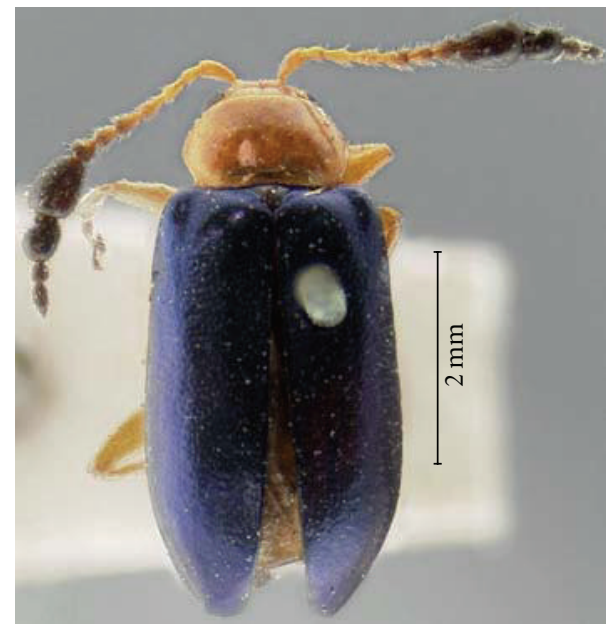

Figure 29: Modified antennae: Metacoryna fulvipes Jacoby.

and found in 40 species and 9 genera. The genus Sermyloides Jacoby has the highest number with the 3rd segment modified, represented by 26 species. The following are some examples of species with the single modified antenna that affect segment 1 (A. cornuta (Figure 4) and Sarawakiola ajaib Mohamedsaid (Figure 12)), segment 3 (Taumacera sucki (Weise) (Figure 13)), segment 4 (Afrocrania kaethae Middelhauve and Wagner (Figure 14) and A. latifrons (Weise)), segment 5 (Apophylia incisitarsis (Laboissiere) (Figure 15)), segment 7 (Duvivieria apicitarsis Weise (Figure 16) and Megalognatha grouvellei (Weise) (Figure 17)), segment 8 (Cerophysa flava Baly (Figure 18) and Cerophysa gestroi Jacoby (Figure 19)), segment 9 (Metacoryna guatemalensis Jacoby (Figure 20) and Agetocera silva (Bezděk) (Figure 21)), segment 10 (Ectmesopus darlingtoni Blake, (Figure 22)) and segment 11 (Aulacophora luteicornis (Fabricius) (Figure 23)). 


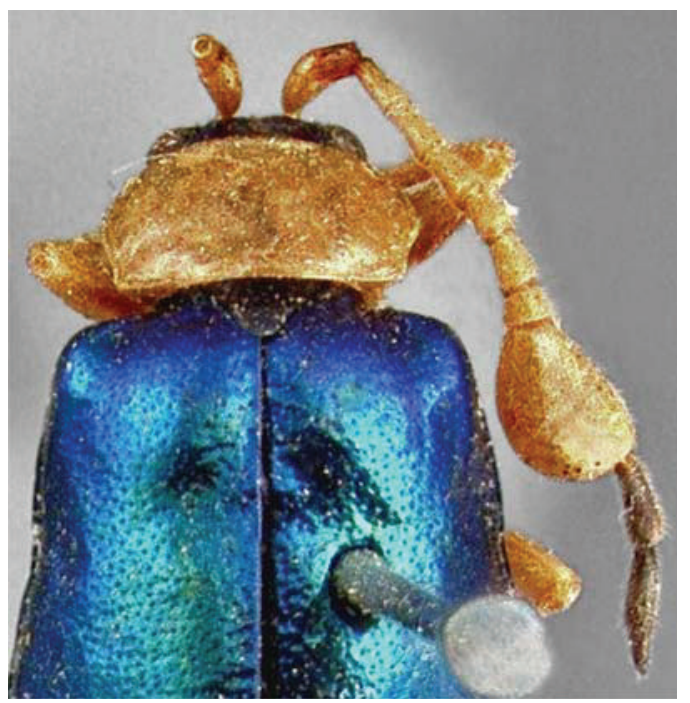

Figure 30: Modified antennae: Metacoryna jacobyi Bowditch.

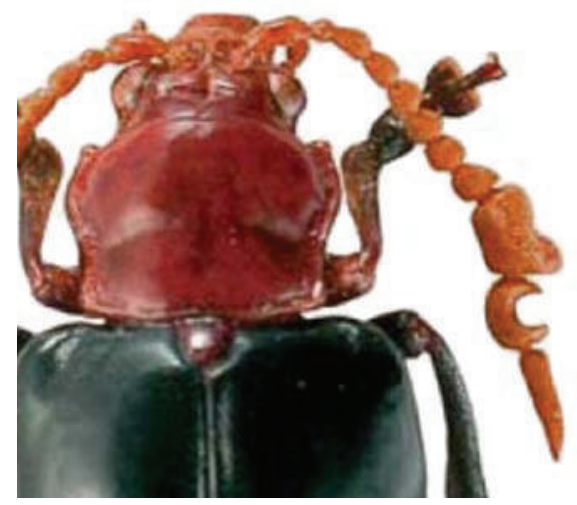

Figure 31: Modified antennae: Agetocera nigripennis Laboissiere.

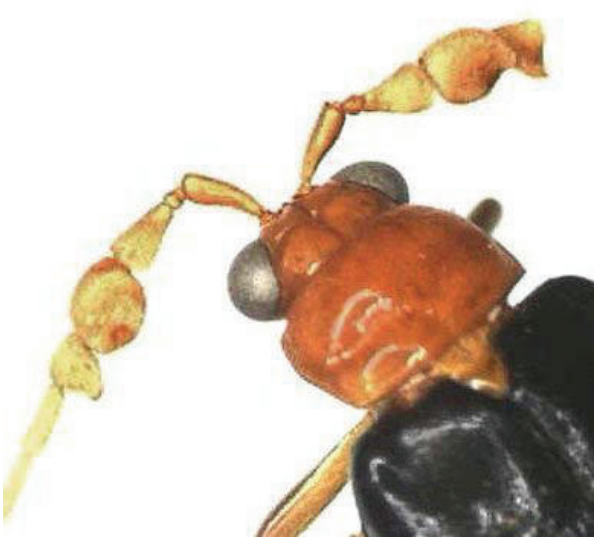

Figure 32: Modified antennae: Aulacophora laevifrons Baly.

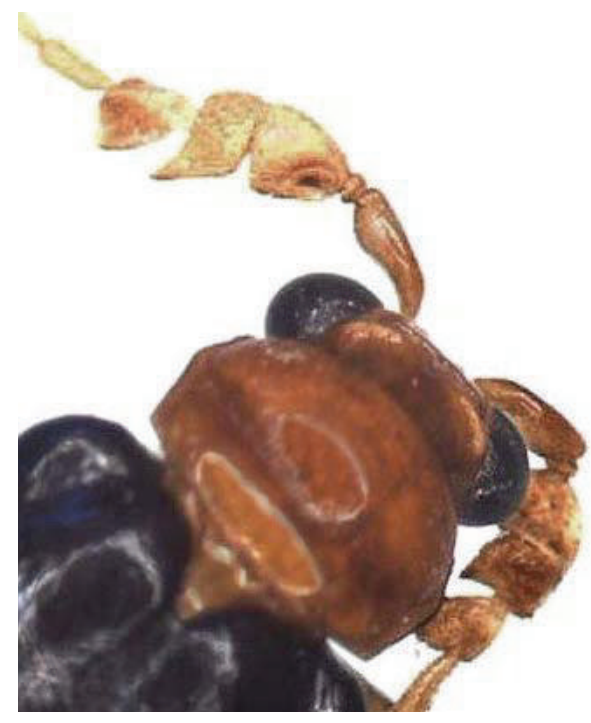

FIgURE 33: Modified antennae: Aulacophora martia Weise.

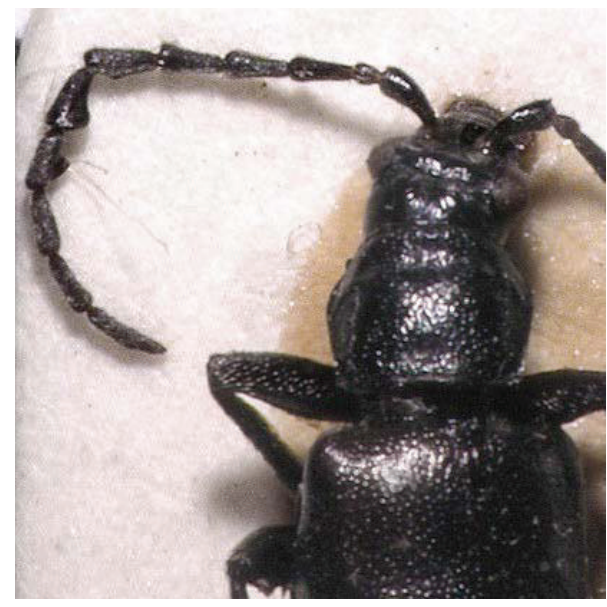

Figure 34: Modified antennae: Megalognatha rolleti Laboissiere.

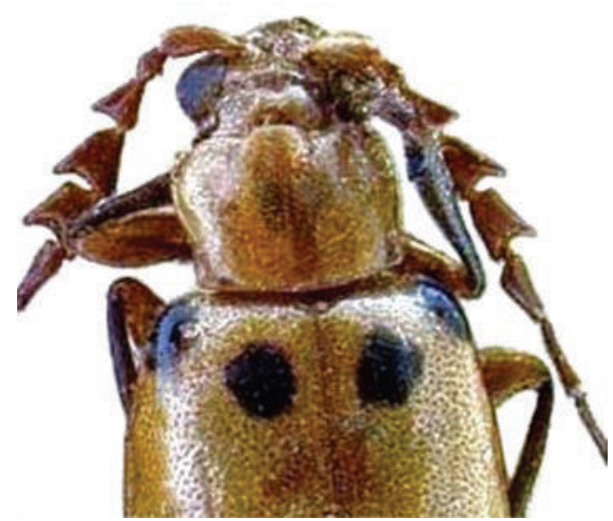

FIgURE 35: Modified antennae: Malacorhinus antennatus Jacoby. 


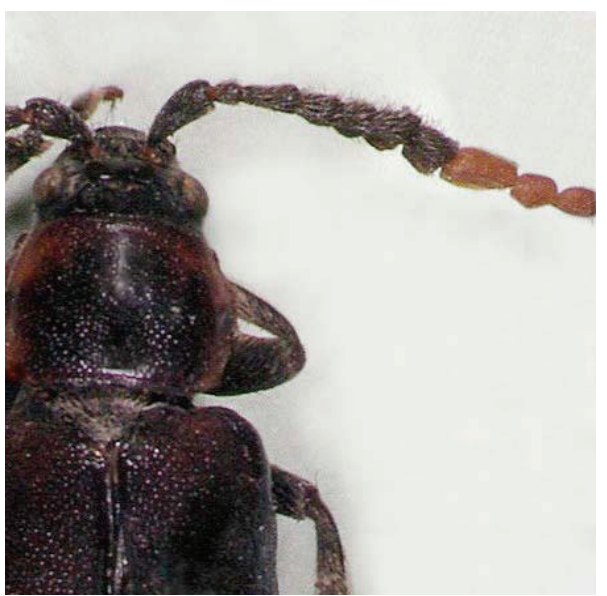

Figure 36: Modified antennae: Megalognatha variicornis Weise.

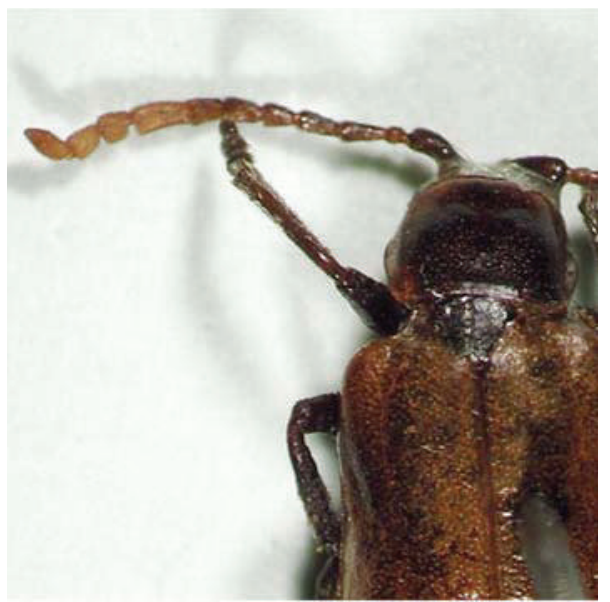

FIGURE 37: Modified antennae: Exosoma deformicornis (Queddenfledt).

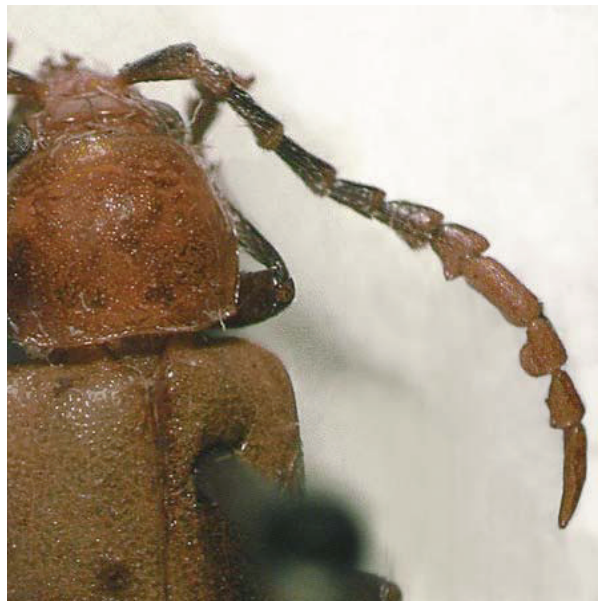

FIGURE 38: Modified antennae: Megalognatha femoralis Laboissiere.

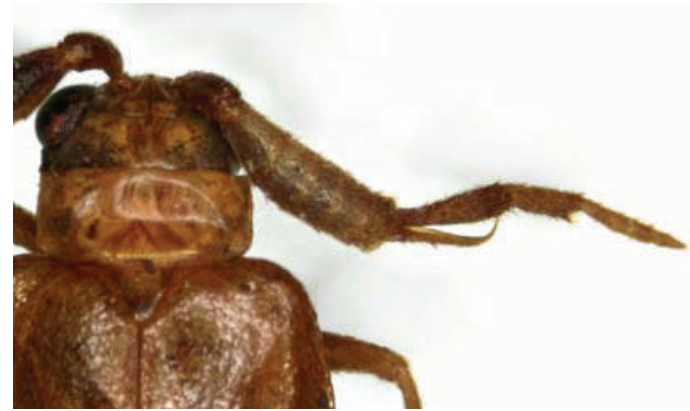

Figure 39: Modified antennae: Xenoda pallid Jacoby.

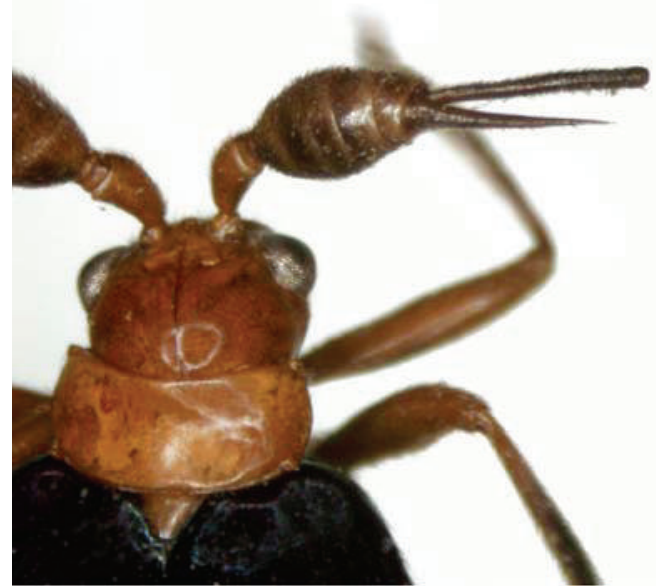

FIgUre 40: Modified antennae: Xenoda ovalis Mohamedsaid.

There are 106 species in 27 genera having a set of double modified antennal segments with segments 3 and 4 the most affected, which is found in 36 species and 12 genera. But the genus Agetocera Hope with the double modifications of segments 8 and 9 has the highest number, represented by 19 species. Examples of species with double modifications of segments 1 and 3 (Taumacera khalednordini Mohamedsaid (Figure 24)), segments 3 and 4 (Hoplosaenidea aerosa (Laboissiere) (Figure 25) and Cerotoma ruficornis (Olivier) (Figure 26)), segments 4 and 5 (Afrocrania foveolata (Karsch)), segments 5 and 6 (Taumaceroides sinicus), segments 6 and 7 (Cerophysa sumatrensis (Jacoby) and Taumacera variceps); segments 7 and 8 (Kinabalua musaamani Mohamedsaid (Figures 27(a) and 27(b))), segments 8 and 9 (Taumacera occipitalis (Laboissiere) (Figure 28), Metacoryna fulvipes Jacoby (Figure 29) and M. jacobyi Bowditch (Figure 30)); segments 9 and 10 (Agetocera nigripennis Laboissiere (Figure 31)). Apparently in Metacoryna jacobyi the modified segments are fused together and appear as one.

There are 97 species in 21 genera having a set of triple modified antennal segments with a combination of segments 3 , 4, and 5 the most commonly affected and found in 36 species and 3 genera. The genus Aulacophora has the highest number of triple modifications, represented by 34 species. Examples of triple modifications are segments 3, 


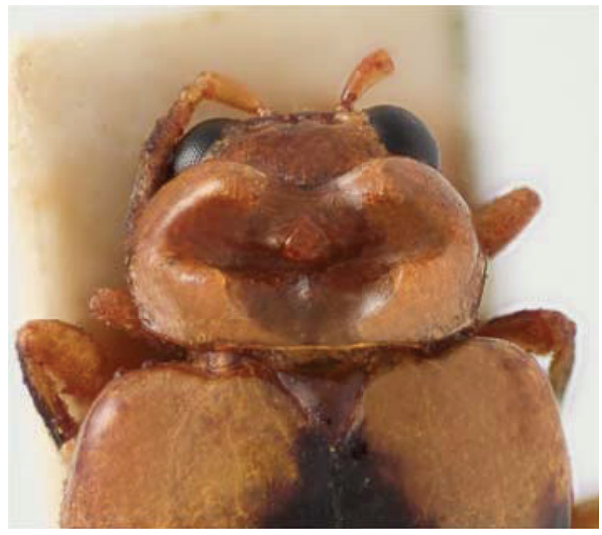

(a)

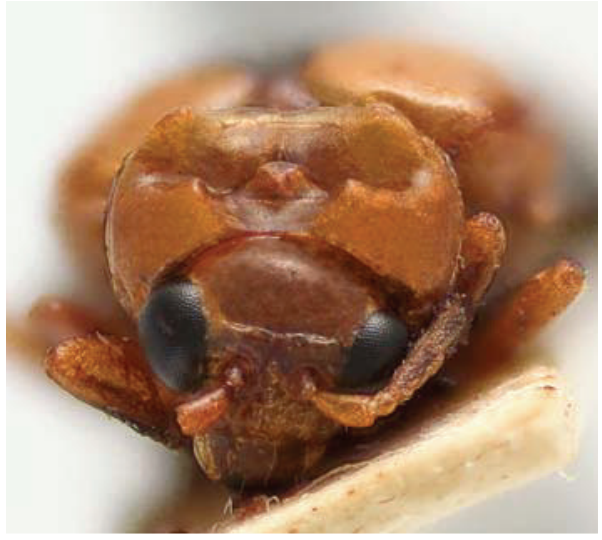

(b)

FIGURE 41: Modified pronotum: Jacobya cavicollis (Faimaire).

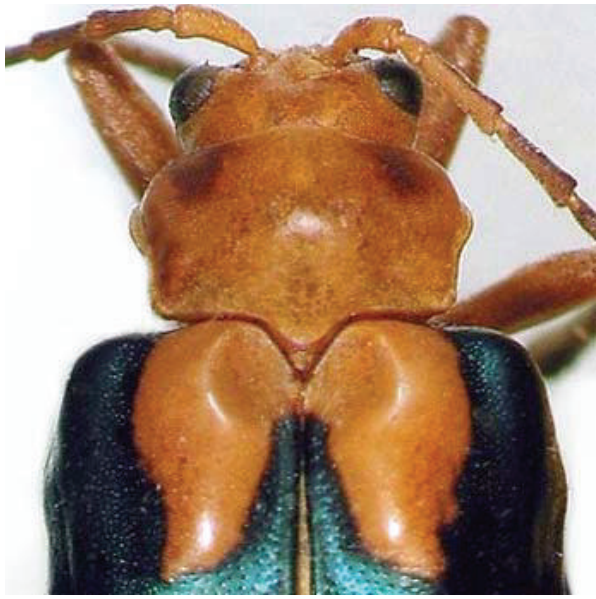

FIgURE 42: Modified pronotum: Cannonia meridionalis (Weise).

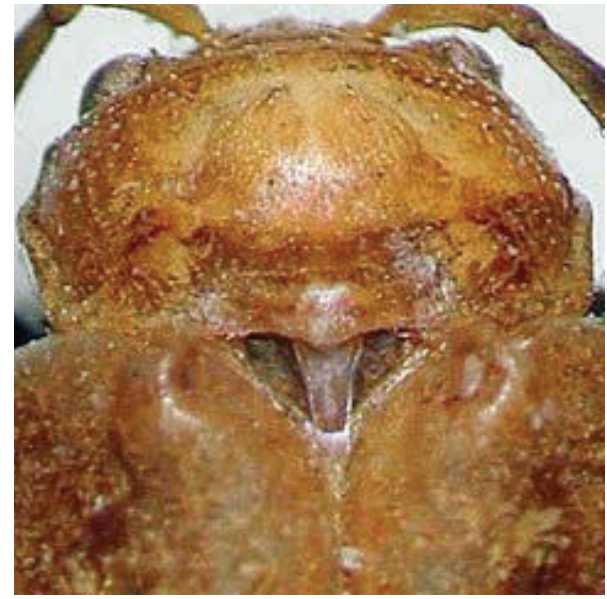

FIgUre 43: Modified pronotum: Prosmidia suahelorum Weise.
4 and 5 (Aulacophora laevifrons Baly (Figure 32) and $A$. martia Weise (Figure 33)), segments 5, 6, and 7 (Paratriarius dorsatus (Say)), segments 6, 7, and 8 (Megalognatha rolleti Laboissiere (Figure 34)), segments 7, 8, and 9 (Paratriarius neocrassicornis (Bowditch)) and segments 9, 10, and 11 (Vitruvia clavicornis Weise).

The modified antenna with more than three segments is the most common and widely distributed, found in 232 species and 71 genera. The genus Xenoda Baly has the highest number with more than three segments modified and represented by 23 species. The affected segments are either a combination of three or more basal, apical, or a combination of almost all the antennal segments. Examples are (Malacorhinus antennatus Jacoby (Figure 35), Megalognatha variicornis (Weise) (Figure 36), Exosoma deformicornis (Queddenfledt) (Figure 37) and Megalognatha femoralis Laboissiere (Figure 38)). However, in the genus Xenoda (subgenus Xenoda), all modified segments 3 to 8 are united into more or less one piece (Xenoda pallida Jacoby (Figure 39) and $X$. ovalis Mohamedsaid (Figure 40)). This union of segments is also found in other species, but it affects two segments, the 8th and 9th, as in Metacoryna jacobyi (Figure 30). Besides affecting the shape of antennal segments, the modified antenna is also the one with the presence of long hairs. There are 55 species in 19 genera having antenna covered with long hairs.

In thorax, these modified structures are found on pronotum, scutellum, elytra, legs, and the ventrite of the third thoracical segment (Table 2 ). The modified pronotum is the least represented, found in 38 species and 10 genera. The pronotum has either the disc bulged or excavated (Jacobya cavicollis (Fairmaire) (Figure 41)), or the middle of posterior margin bearing a short process or knob (Cannonia meridionalis (Weise) (Figure 42)). In an isolated case, scutellum for three species of Prosmidia is transformed into tongue-liked shape ( $P$. suahelorum Weise (Figure 43)). In addition, these species also have both pronotum excavated and elytra with a pair of tubercles.

Modified elytra are the most widely distributed and found in 304 species and 30 genera (Table 2). The number 


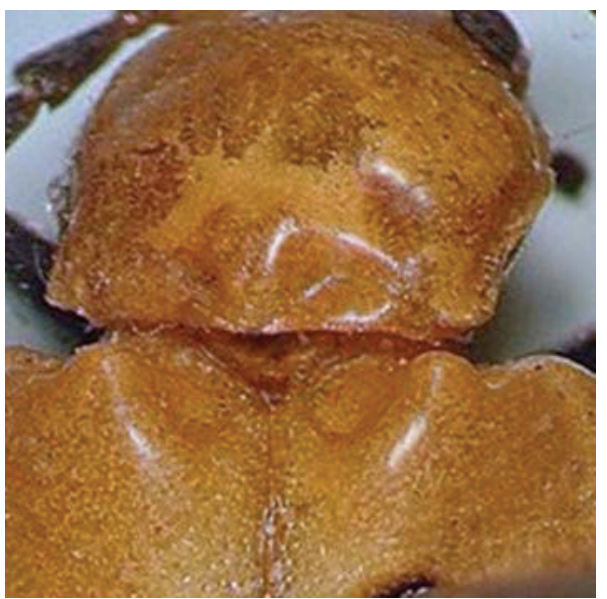

FIGURE 44: Modified elytra: Laetiacantha distincta (Gahan).

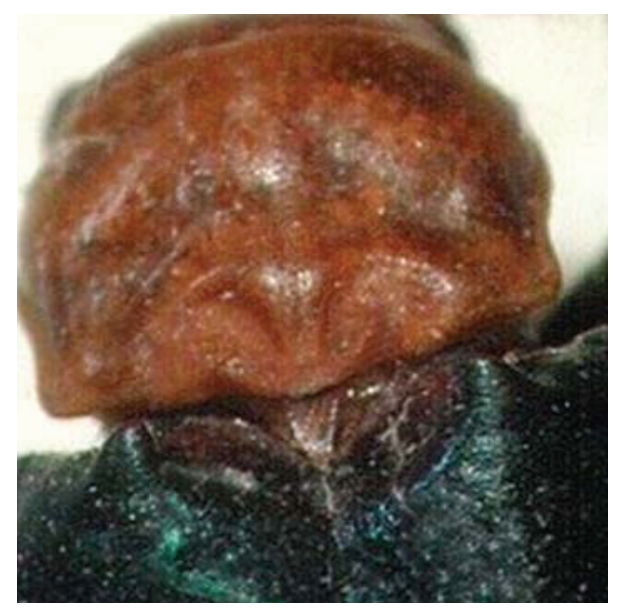

FIgURE 45: Modified elytra: Laetiacantha ruficollis Laboissiere.

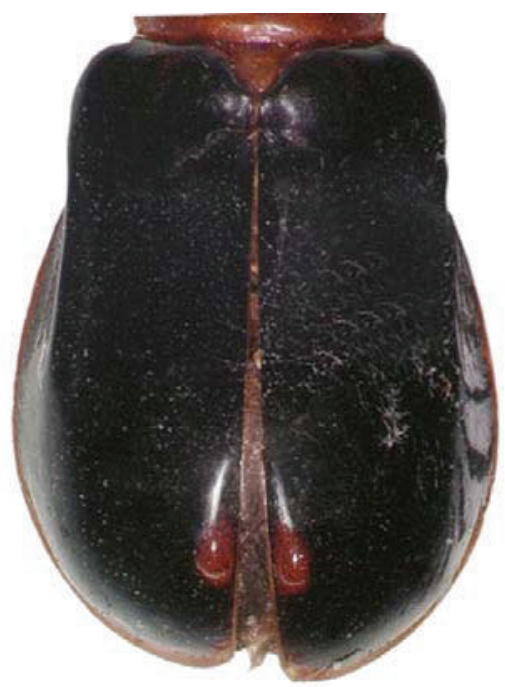

FIgURE 46: Modified elytra: Diacantha senegalensis (Laboissiere).

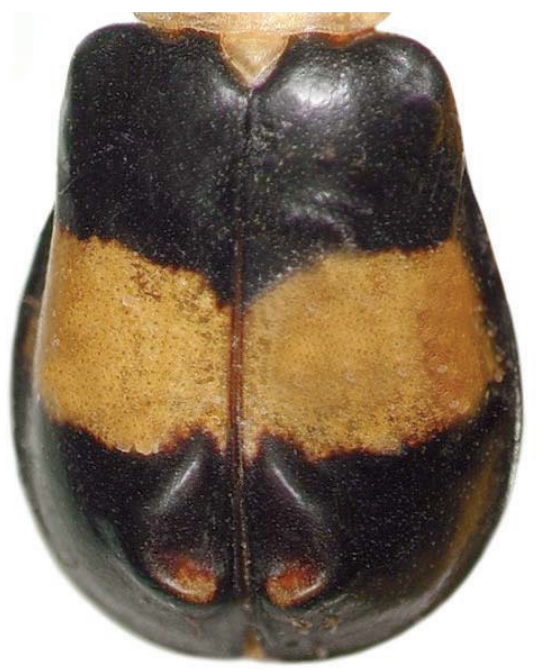

Figure 47: Modified elytra: Diacantha insignipennis Thomson.

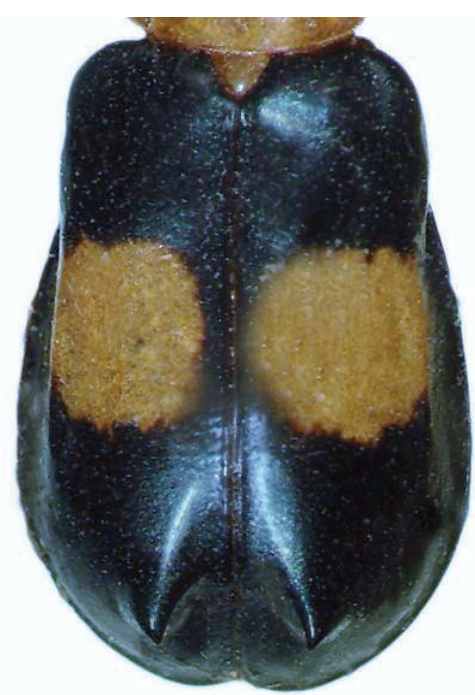

FIgure 48: Modified elytra: Diacantha varians Weise.

of species with modified elytra amounts to $24 \%$ of the total modified Galerucinae. There are two types of modified elytra, one is with the presence of tubercles and the other with cavities. The modified structures are located either at base, posterior to scutellum or between scutellum and humeri laterally, or at the apex of the elytra. In Elyces quadrimaculata Jacoby the humerus is strongly tuberculate. A pair of tubercles is located either at the base of elytra (Laetiacantha distincta (Gahan) (Figure 44) and Laetiacantha ruficollis Laboissiere (Figure 45)), or at the apex of elytra, found in 81 species of the genus Diacantha Chevrolat. The tubercles have various sizes and shapes, such as rounded (Diacantha senegalensis (Laboissiere) (Figure 46)), pointed (D. insignipennis Thomson (Figure 47) and D. varians Weise (Figure 48)), bifurcate (D. cupripennis (Laboissiere) 


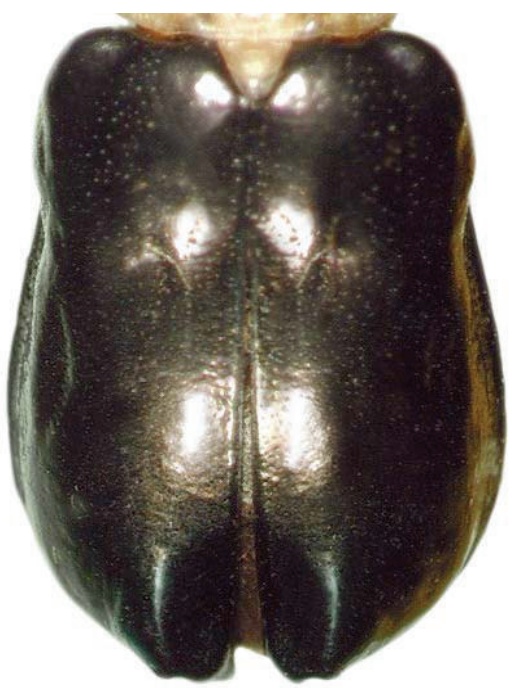

Figure 49: Modified elytra: Diacantha cupripennis (Laboissiere).

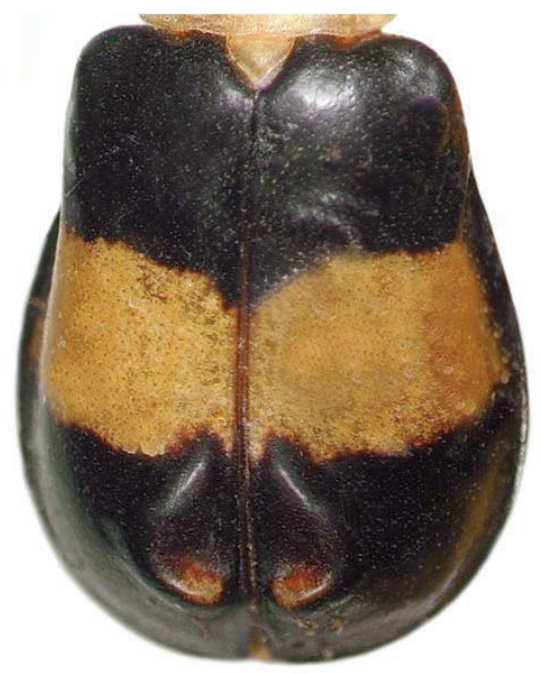

Figure 50: Modified elytra: Diacantha bituberculata (Fabricius).

(Figure 49)), semicircular-shaped (D. bituberculata (Fabricius) (Figure 50)), and elongate and parallel to the suture (D. dimidiata (Laboissiere) (Figure 51)). In an extreme case the tubercle forms a long lateral carina, extending from the humeri to apex (Candezea bicostata (Weise) (Figure 52)).

Opposite to the formation of a tubercle, the elytra are excavated. There are various sizes and shapes of the cavities, as well as their depth. The cavities are located on various parts of the disc, posterior to the scutellum, in the middle, at sides, or at apex of the elytra. The most common are located at posterior of the scutellum. Simple excavated elytra have traces of a cavity, or with shallow depression (Afrocrania ubatubae Middelhauve and Wagner (Figure 53)), with a straight groove (Paleosepharia jambuica Mohamedsaid

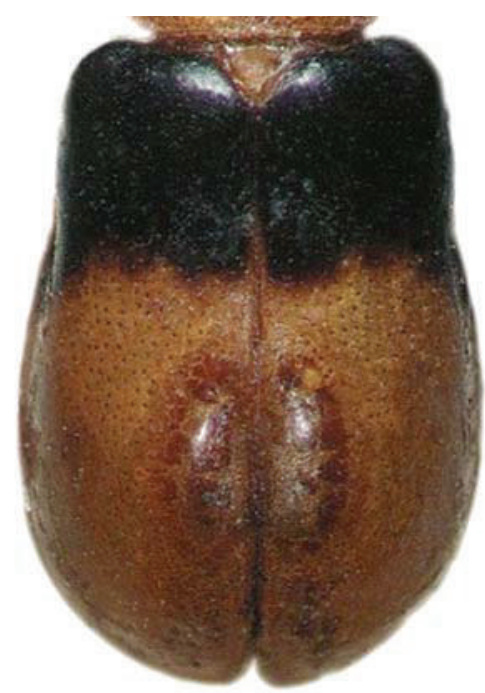

Figure 51: Modified elytra: Diacantha dimidiata (Laboissiere).

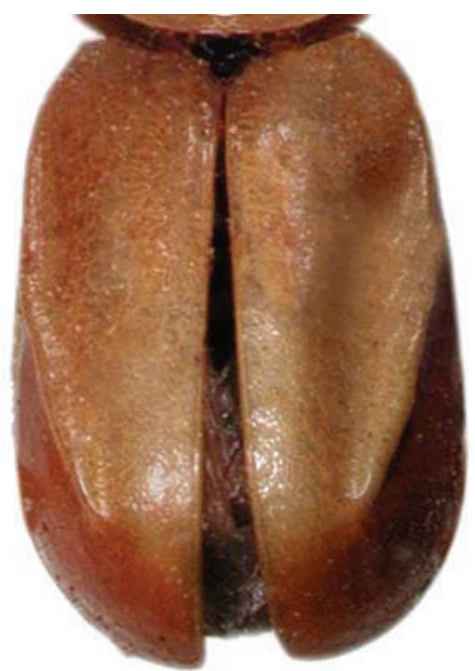

Figure 52: Modified elytra: Candezea bicostata (Weise).

(Figure 54)), an outward oblique at the posterior (P. zakrii Mohamedsaid (Figure 55), P. lawa Mohamedsaid (Figure 56) and P. legenda Mohamedsaid (Figure 57)), or a spindleshaped cavity (P. tenasserimensis (Maulik) (Figure 58)). In Monolepta kerangas (Mohamedsaid) (Figure 59), the cavity is located in the middle and the elytra humpbacked view from side. A few species have the cavity located at apex of elytra (Paratriarius alternans (Weise); Strobiderus excavatus Jacoby). In other species, the cavity is funnel shaped and located at the base between scutellum and humerus (Neolaetana alternans (Silfverberg)). Pseudocrania basalis Jacoby (Figure 60) has the broadest excavated elytra. In addition, in the following two genera: Malacorhinus Jacoby and Androlyperus Crotch, the cavities are located 


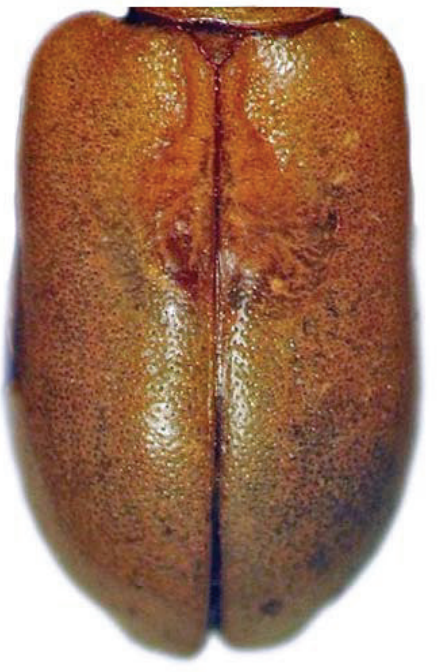

Figure 53: Modified elytra: Afrocrania ubatubae Middelhauve and Wagner.

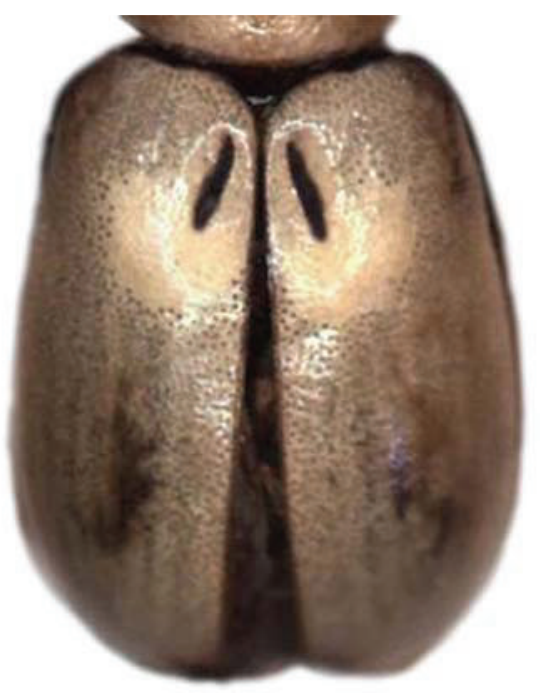

FIgUre 54: Modified elytra: Paleosepharia jambuica Mohamedsaid.

at the sides. In the former, the cavities are located in the middle and the latter near the apex of the elytra. Examples are M. decempunctatus Jacoby (Figures 61(a) and 61(b)), M. foveipennis Jacoby (Figure 62), M. tripunctatus Jacoby (Figure 63) and A. nataliae Clark (Figure 64). Another type of modified elytra is with the presence of rows of erect hairs on shoulders, which is found in five species of Aulacophora.

The modified leg includes modifications on any part of it, which include trochanter, femur, tibia, tarsus, and claws. There are 401 species in 88 genera with modified legs (Table 2). The number of species with modified leg amounts to $31 \%$ of the total modified Galerucinae. The affected part of the leg is either enlarged, emarginated, excised, with a process, or spine, or having a different set

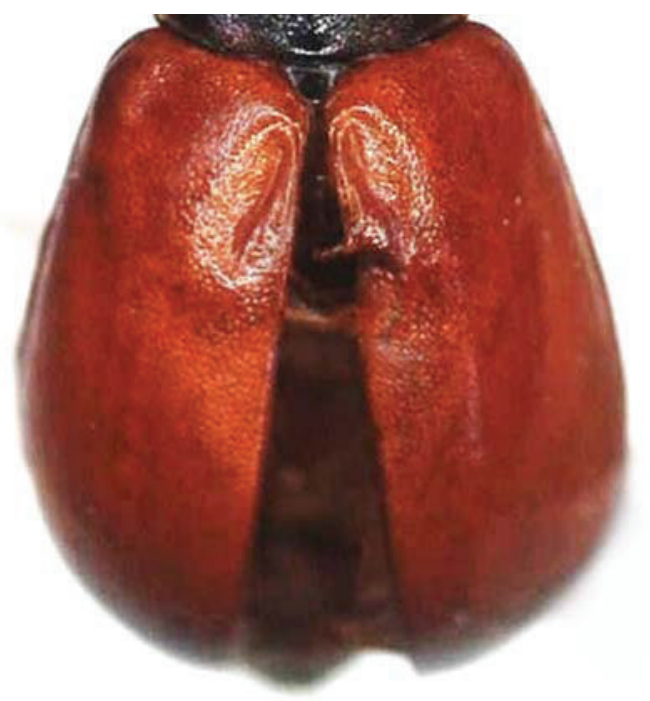

Figure 55: Modified elytra: Paleosepharia zakrii Mohamedsaid.

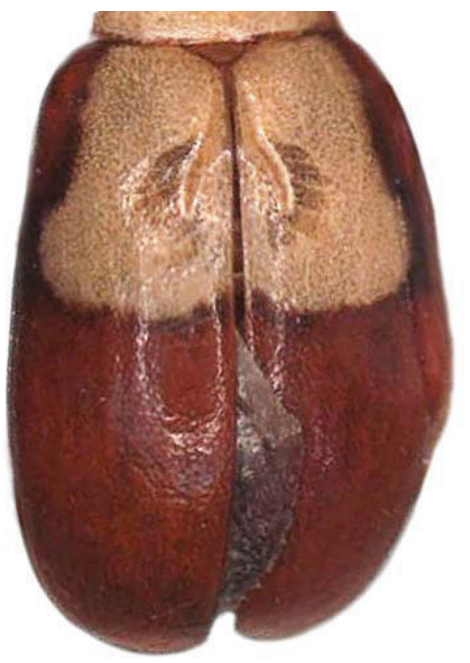

Figure 56: Modified elytra: Paleosepharia lawa Mohamedsaid.

of tarsal claws. The male has bifid tarsal claws in contrast to the female with either appendiculate or simple claws. The genus Apophylia Thomson, represented by 148 species, has a characteristic of bifid tarsal claws differing from females that have appendiculate claws. Another genus with the male having bifid tarsal claws is Erynephala Blake, represented by 5 species.

The modified tibia is the widely distributed modification of the leg, represented by 103 species and 39 genera. Examples of part of the modified leg are metatrochanter with a long spine in Coeligetes borneensis Mohamedsaid (Figure 65); protibia enlarged in Mombasa magna (Weise) (Figure 66) and Cerotoma dilatipes Jacoby (Figure 67); protibia emarginate in Taumacera tibialis Mohamedsaid (Figure 68); 


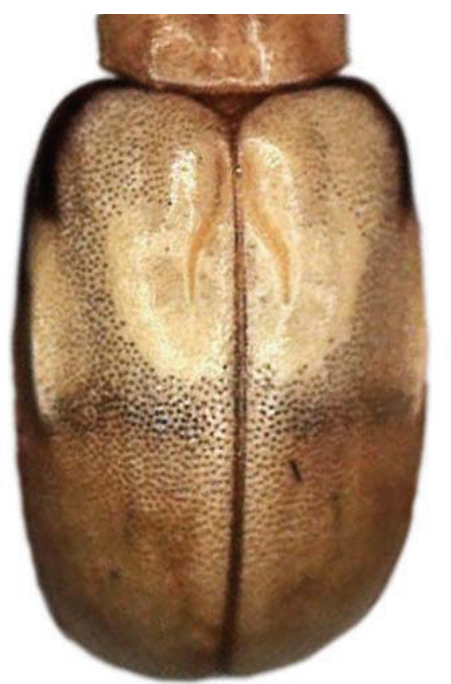

Figure 57: Modified elytra: Paleosepharia legenda Mohamedsaid.

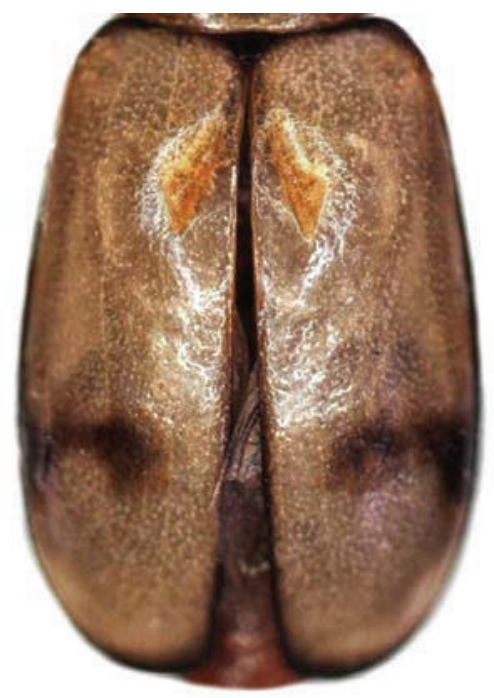

FIGURE 58: Modified elytra: Paleosepharia tenasserimensis (Maulik).

mesotibia emarginated in Dreeus distinctus (Shute) and Taumacera midtibialis Mohamedsaid (Figure 69); metatibia curved and with a tooth in the middle in Scelolyperus tejonicus Crotch (Figure 70). In the two rare species, Sastroides tarsalis Mohamedsaid and Momaea distincta Mohamedsaid (Figures 71(a) and 71(b)), two parts of the same leg are modified, the mesotibia and mesotarsus, with the former excavated and covered with a series of pegs and the latter has a long process. A modified first segment of protarsus is common in the Chrysomelidae, but in some Galerucinae, it is strongly dilated as in Taumacera yamamotoi (Mohamedsaid) (Figure 72).

The thorax also has the modified structures on the venter of its third segment, known as the metasternum, and this is found in 60 species and 4 genera. The modified

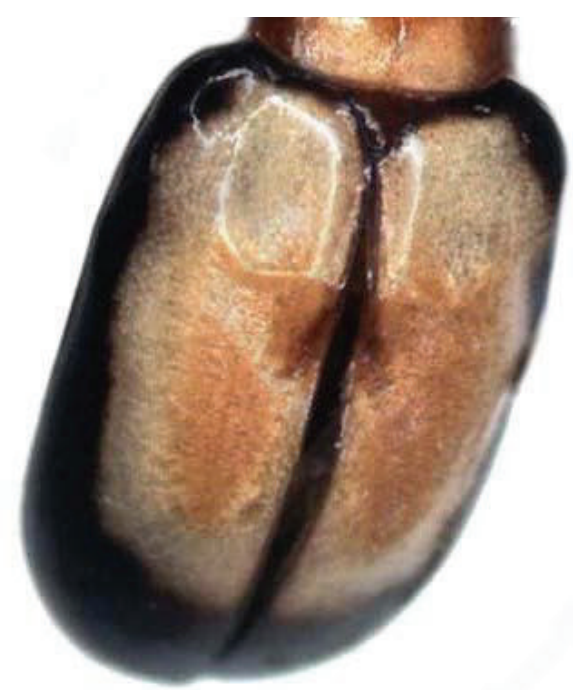

Figure 59: Modified elytra: Monolepta kerangas Mohamedsaid.

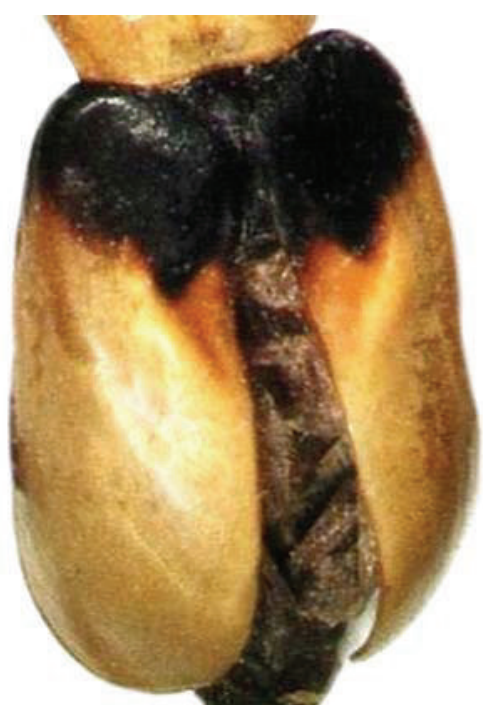

FIgure 60: Modified elytra: Pseudocrania basalis Jacoby.

metasternum is present in tubercle (Apophylia nobilitata Gerstaecker (Figure 73)), an elongated lobe (Kinabalua musaamani Mohamedsaid (Figure 74)) or a laminated lobe (Taumacera midtibialis (Figure 75)). Besides, in Cneoranidea hirta (Yang), the metasternum is covered with long hairs.

The abdomen has the sternite with modified structures in the present appendages, tubercles, and hairs. There are 66 species in 18 genera with modified abdomen (Table 2). The number of species with modified abdomen amounts to $5 \%$ of the total modified Galerucinae. The genus Hoplasoma Jacoby has the highest number with modified abdomen, represented by 13 species. The modified abdominal sternite are either densely covered with long hairs (Hemygascelis longicollis Jacoby (Figure 76)), or bearing one piece (Haplosomoides 


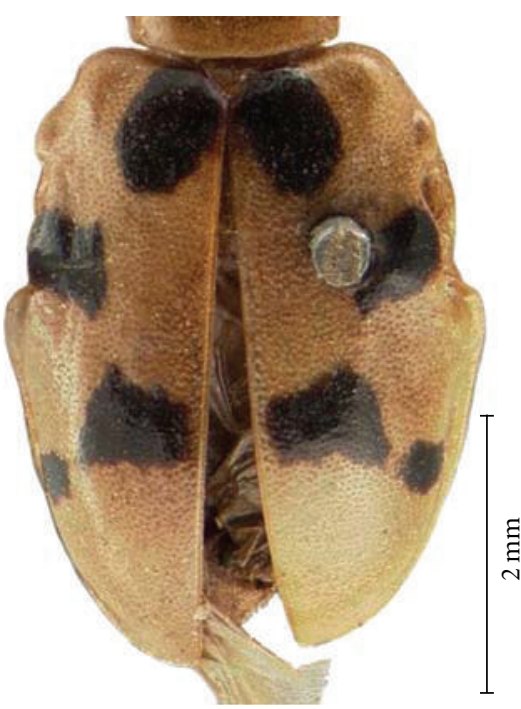

(a)

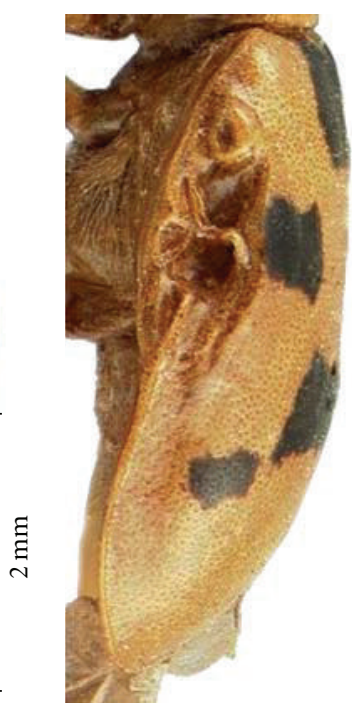

(b)

FIgURE 61: Modified elytra: Malacorhinus decempunctatus Jacoby.

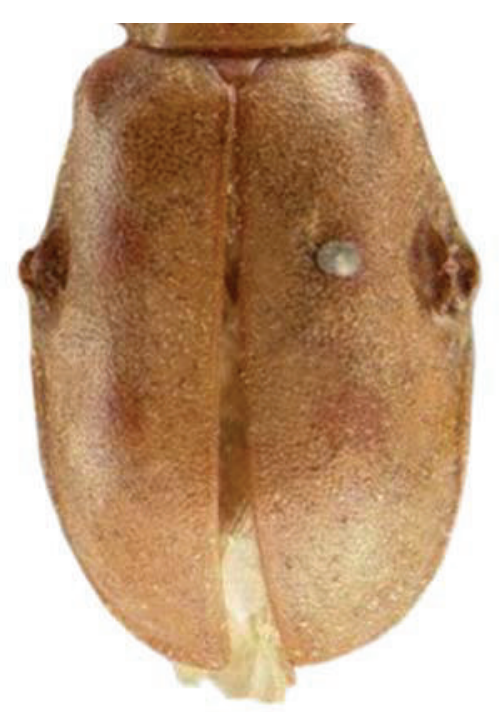

FIgURE 62: Modified elytra: Malacorhinus foveipennis (Jacoby).

chinmatra Maulik (Figure 77)), a pair (Coeligetes submetallica Jacoby (Figure 78) and Hoplasoma unicolor (Illiger) (Figure 79)), or two pairs of appendages (H. apicale Jacoby (Figure 80), Androlyperus fulvus Crotch (Figure 81) and Scelida flaviceps (Horn) (Figure 82)). Also a complex abdominal appendage is found in species of Nymphius Weise (N. ensifer (Guillebeau) (Figure 83), N. forcipifer (Weise) (Figure 84), N. gianassoi Bezděk (Figure 85), N. lydius (Weise) (Figure 86), N. ogloblini (Bogachev) (Figure 87), N. pravei (Jacobson) (Figure 88), and N. stylifer (Weise) (Figure 89)).

Table 4 presents a list of 49 largest genera represented by at least 5 species. These genera represent 1007 species or $74 \%$ of the total 1298 species presently listed. The genus Apophylia has the highest number of species (148) with modified structures followed by Diacantha (81), Megalognatha (59), Aulacophora (54), and Taumacera (45). However, the most common form of SCC is the modified antennae, followed by the modified elytra and the modified head.

Worldwide distribution of modified Galerucinae both from the Old and New Worlds has the former represented by $88 \%$ of the total modified species of the subfamily. The Luperini is the major tribe and represented by $84 \%$ of the total modified species in the Galerucinae. The Old World Luperini has the highest representation of SCCs with $87 \%$ of the total modified Luperini. The Galerucini from the Old World has the highest representation with $90 \%$ of the total modified from the tribe.

\section{Discussion}

A total of 1298 species and 172 genera of the Galerucinae (sensu stricto) with SSCs are recorded; a huge number. The modified species represent about $24 \%$ of the total number of the Galerucinae, based on an estimate of 5500 species [2]. However, we believe that there are many more species with SSCs that either we were not aware of or were not available for our examination. Our observations were mainly based on original descriptions and illustrations and images of types that are posted on websites of various institutions. However, there are many species that were described based on female specimens and/or are the only images posted on websites. There is a high possibility that males belonging to a species that was described based on a female have modified characteristics, but there are no images or subsequent descriptions of males of these species. In certain species, we know that some congeneric species described based on 


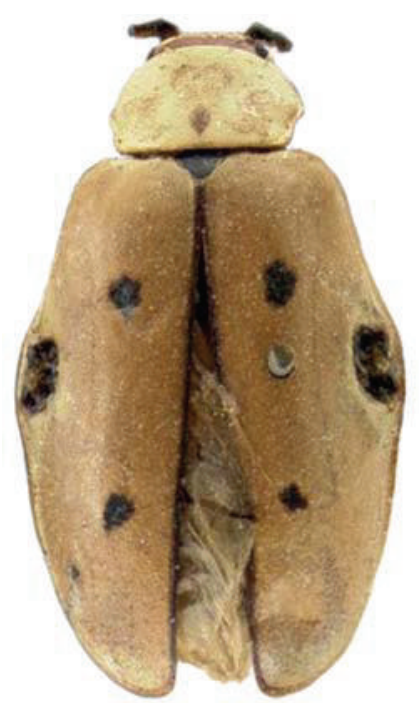

Figure 63: Modified elytra: Malacorhinus tripunctatus (Jacoby).

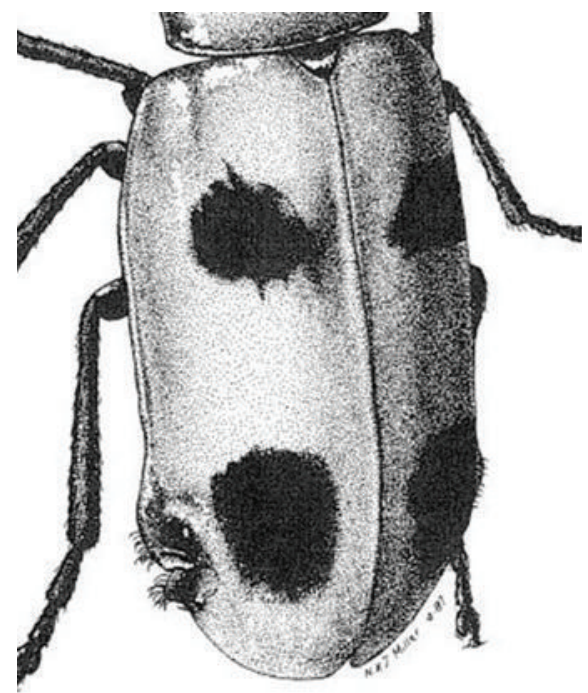

Figure 64: Modified elytra: Androlyperus nataliae Clark.

the female have males with modified characteristics. We also know that not all males of congeneric species have SSCs; therefore, we cannot make an assumption that a particular species described based on female has male with modified characteristics without examining the specimen, and such a species is discounted in the present study. Despite these deficiencies, we believe that our compilation of species of the Galerucinae with SSCs is representative for the subfamily. We believe that this study has covered more than $80 \%$ of all known species of the Galerucinae from around the world and recorded well the presence of the secondary sexual characteristics.

Among the three body parts (head, thorax, and abdomen), the head with various modified structures (vertex, frontal tubercles, clypeus, labrum, maxillary palpi, and antennae) has the widest representation in the Galerucinae, found

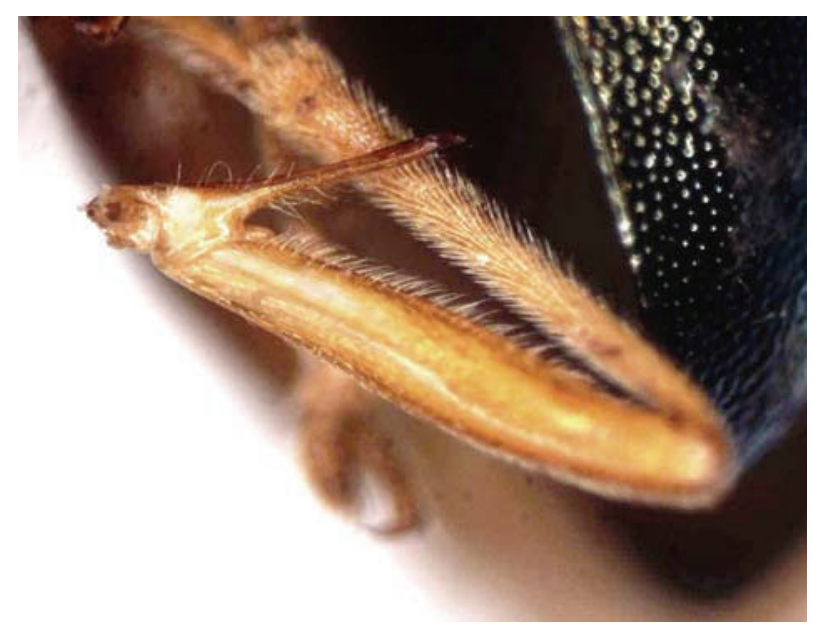

Figure 65: Modified legs: Coeligetes borneensis Mohamedsaid.

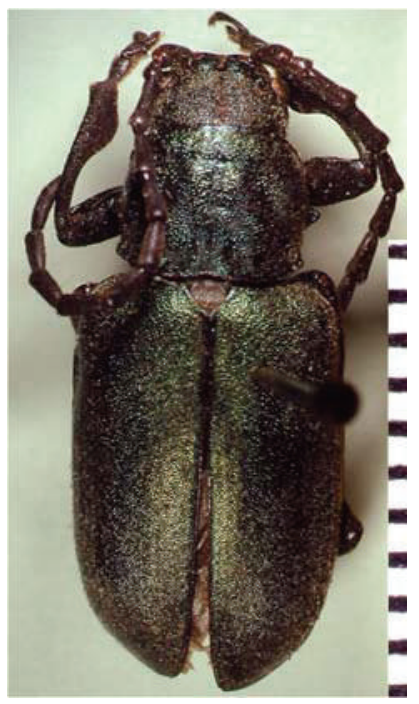

Figure 66: Modified legs: Mombasa magna (Weise).

in 756 species and 119 genera. The thorax with modified pronotum, elytra, third thoracic sternite, and legs is found in 379 species under 37genera. In the modified thorax, the elytra have the highest representation with 304 species, followed by modified first foretarsal segments with 158 species. The ventrites with the modified third thoracic sternite and abdominal sternites combined are found in 126 species of 20 genera. In the modified head, the antennae have the highest representation with 645 species, followed by modified clypeus with 181 species. Modifications of the head occur in 756 species or $58 \%$ of the total modified Galerucinae, and of these 645 species have modified antennae (50\% of the total) also higher than modifications found in other parts of the body, such as thorax and abdomen.

Generally, the distribution of modified structures on a body part is associated with their function. Modified 


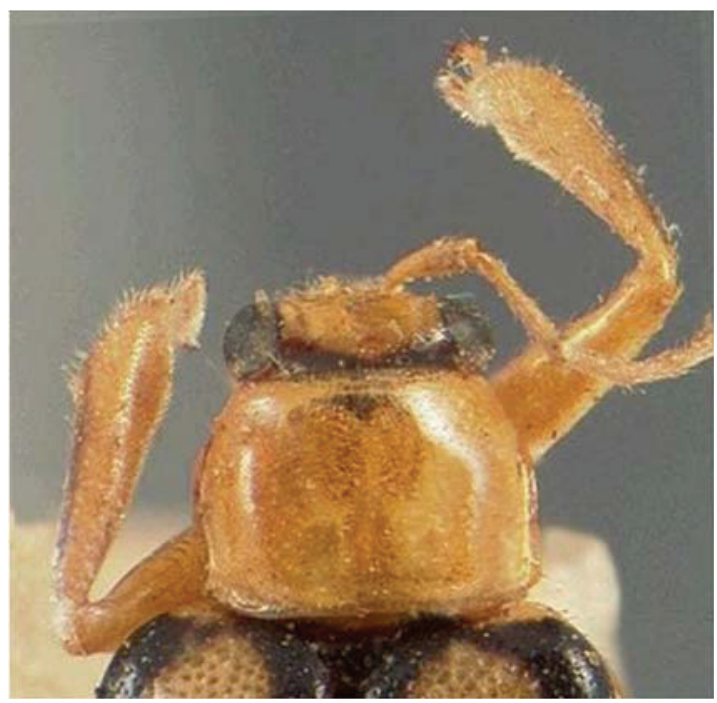

Figure 67: Modified legs: Cerotoma dilatipes Jacoby.

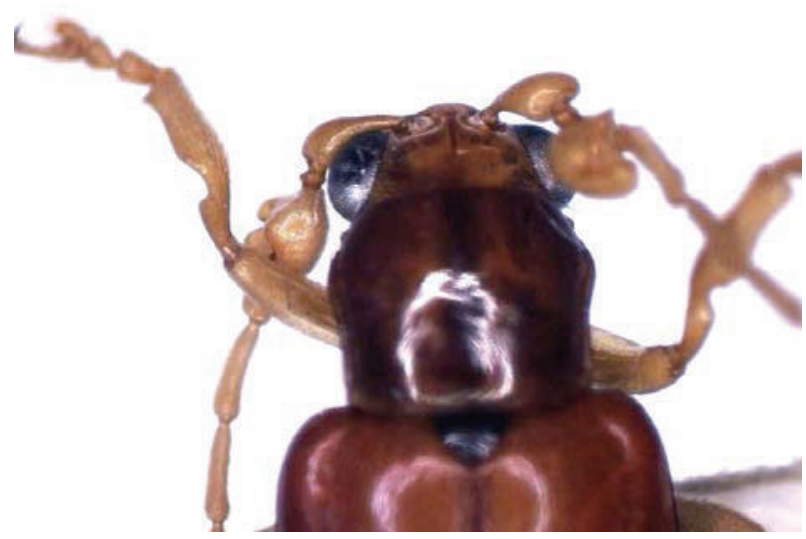

FIgURE 68: Modified legs: Taumacera tibialis Mohamedsaid.

structures on the head may be associated with olfaction and to a lesser extent with some modified pronota and elytra having hairs or sensillae. Modified structures on the thorax, especially on the legs, are associated with precopulatory behaviour. Also the modified abdomen is associated with precopulatory behaviour. Details of these modified structures are discussed below. There are certainly many more examples of SSCs of which we are not yet aware but will be discovered in the future. The record of Galerucinae having the SSC is growing. Since 2005, 78 species were described including 9 that were described in 2010 and recently 2 in 2011 (see Appendix B, list of species).

\section{Peculiar Form of SSCs}

Interestingly, the antennae and tarsal claws are two characters that have some of the most peculiar forms of SSCs in the Galerucinae. Usually the number of antennal segments is the same in both males and females, that is, 11 segments in almost all the Galerucinae, and fewer than that in a few

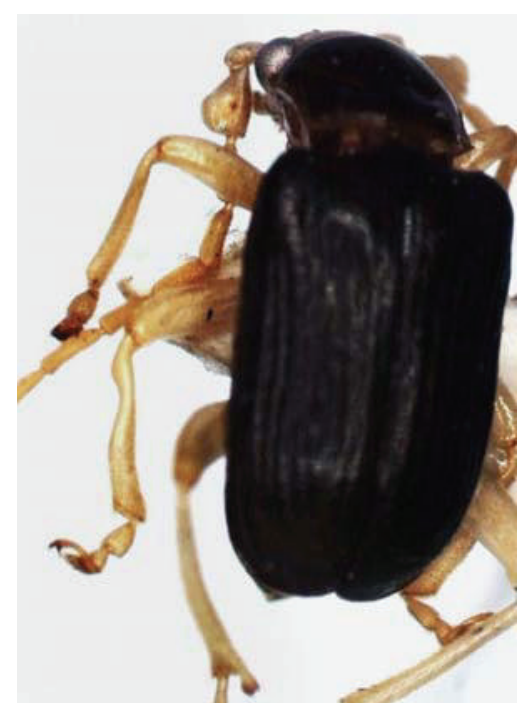

Figure 69: Modified legs: Taumacera midtibialis Mohamedsaid.

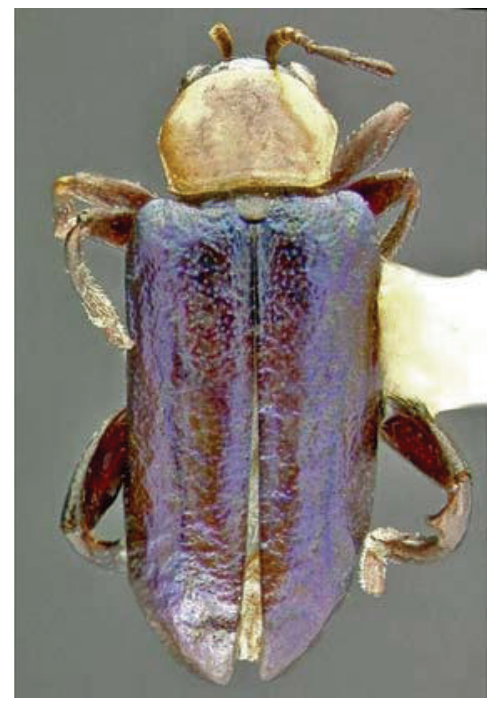

Figure 70: Modified legs: Scelolyperus tejonicus Crotch.

genera of the subfamily Alticinae (sensu stricto), for example, 9 segments in Nonarthra Baly, and 10 segments in Psylliodes Latreille Monotalla Bechyné, and Deciplatus Linzmeier and Konstantinov. However, in a couple genera of Galerucinae, there is a difference in the antennal segments between male and female. In Oroetes Jacoby and Phyllectris Dejean the males have 10 antennal segments (O. flavicollis, P. gentilis (Leconte)) compared with females having 11 segments. There is no apparent explanation as to why the male has less segments than the female.

It is common for both males and females to possess the same characteristics of the tarsal claws, either simple, bifid, or appendiculate. However, in Apophylia, the males have bifid tarsal claws versus appendiculate claws in the females, and in Erynephala Blake, males also have bifid claws, but 


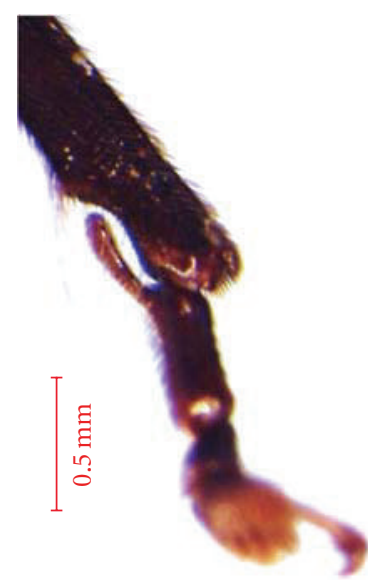

(a)

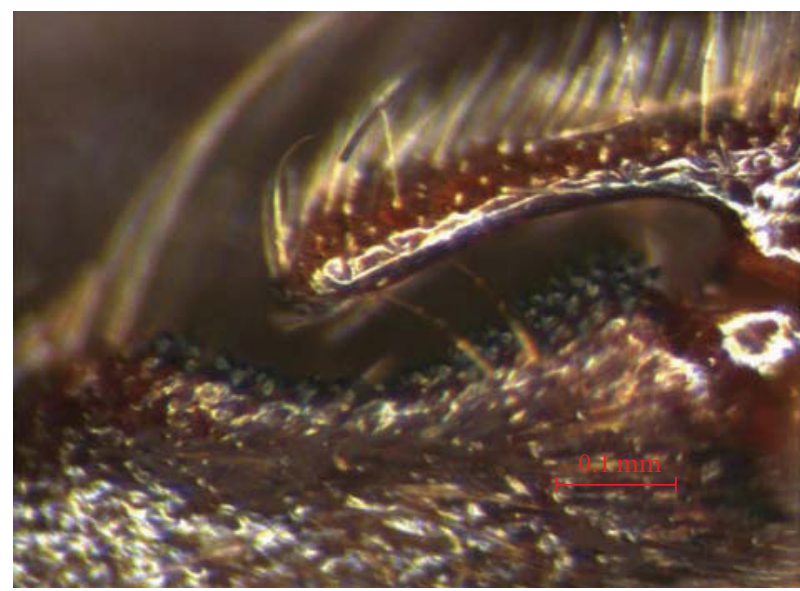

(b)

FIGURE 71: Modified legs: Momaea distincta Mohamedsaid.

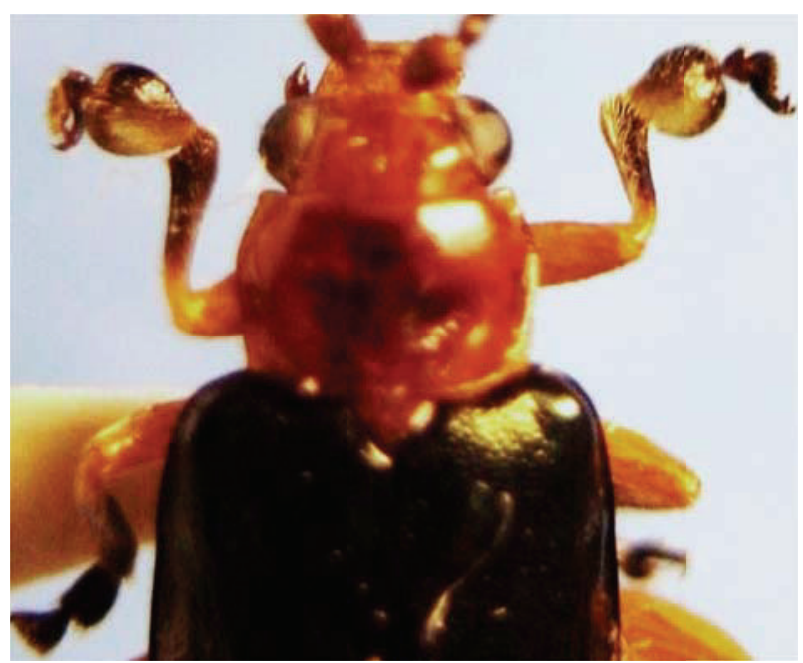

Figure 72: Modified legs: Taumacera yamamotoi (Mohamedsaid).

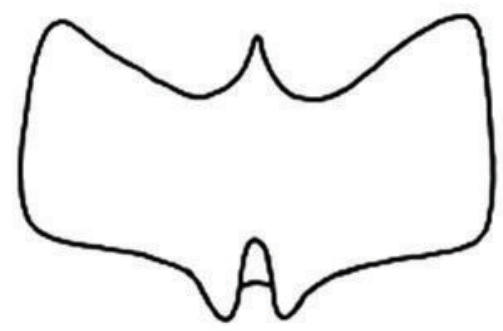

FIgure 73: Modified ventrite of thorax: Apophylia nobilitata Gerstaecker.

females have simple claws. The beetles of the genus Apophylia have the elytral surfaces closely punctuate, appearing rugose. The same is true for the elytral surface of Erynephala that have closely but moderately coarse punctures. Thus,

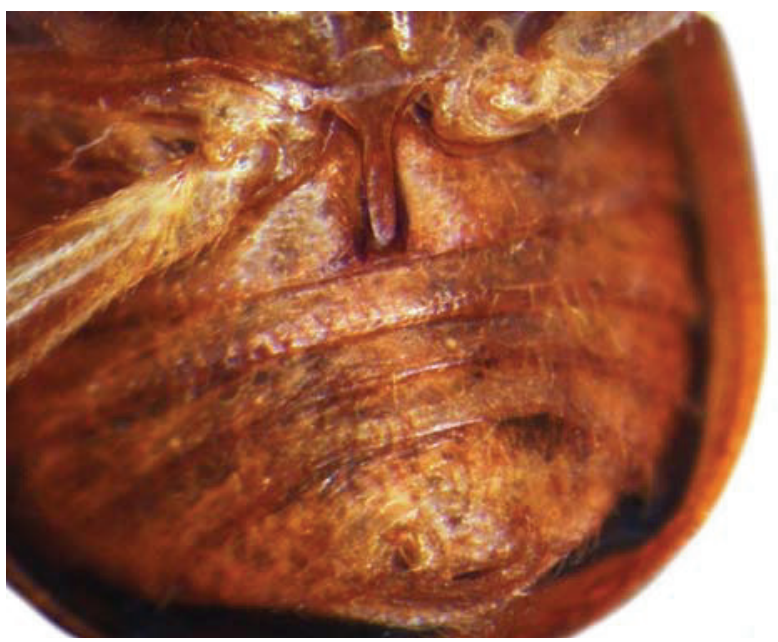

FIgURE 74: Modified ventrite of thorax: Kinabalua musaamani Mohamedsaid.

it is speculated that the male uses its bifid tarsal claws to hold onto the rugose surface of the female elytra during copulation. Of course, there are many genera with both males and females with the same tarsal claws, either bifid or appendiculate and with the rugose elytra.

\section{Functions of SSCs}

More than 1000 species have SSCs with more than two modified structures, and some 100 species have three or more modified structures. The presence of more than one type of SSC is also known as having multiple sexual ornaments. There are several hypotheses attempting to explain why a male would have multiple sexual ornaments. One of these is the multiple messages hypothesis, which states that each trait display reflects only one aspect of the overall quality of 


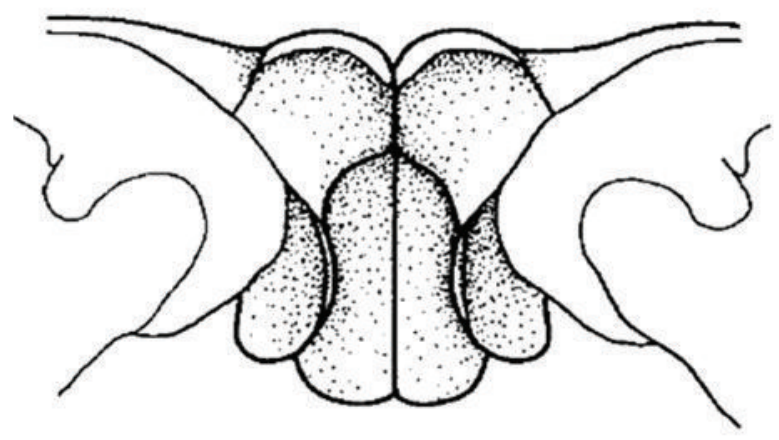

FIgURE 75: Modified ventrite of thorax: Taumacera midtibialis Mohamedsaid.

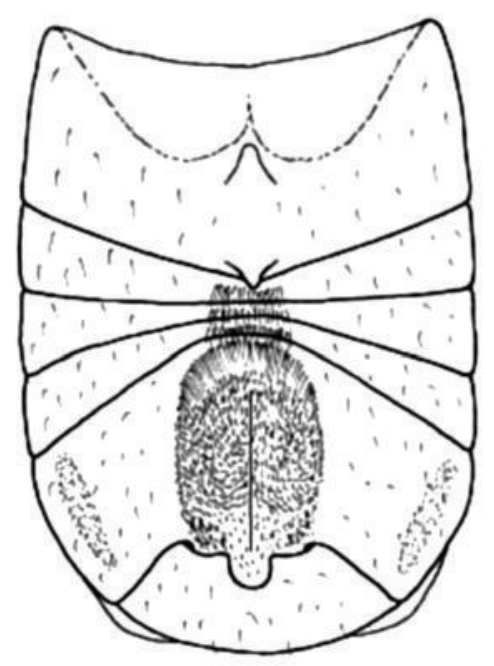

FIgure 76: Modified abdomen: Hemygascelis longicollis Jacoby.

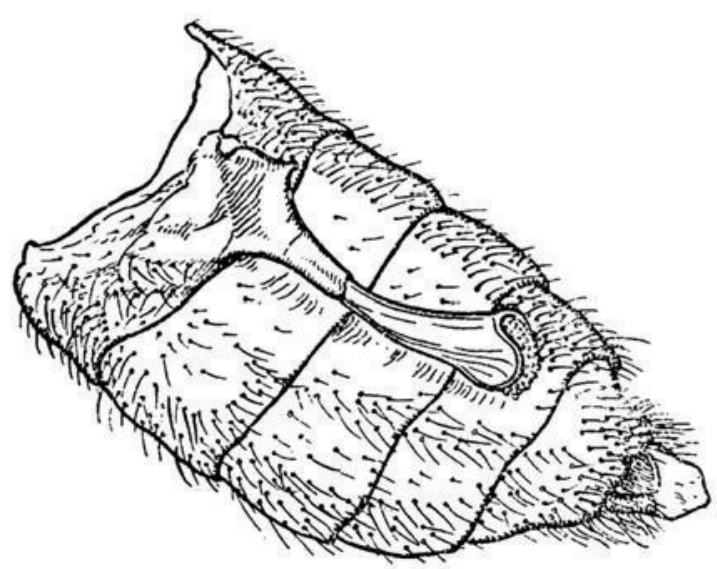

FIgURE 77: Modified abdomen: Haplosomoides chinmatra Maulik.

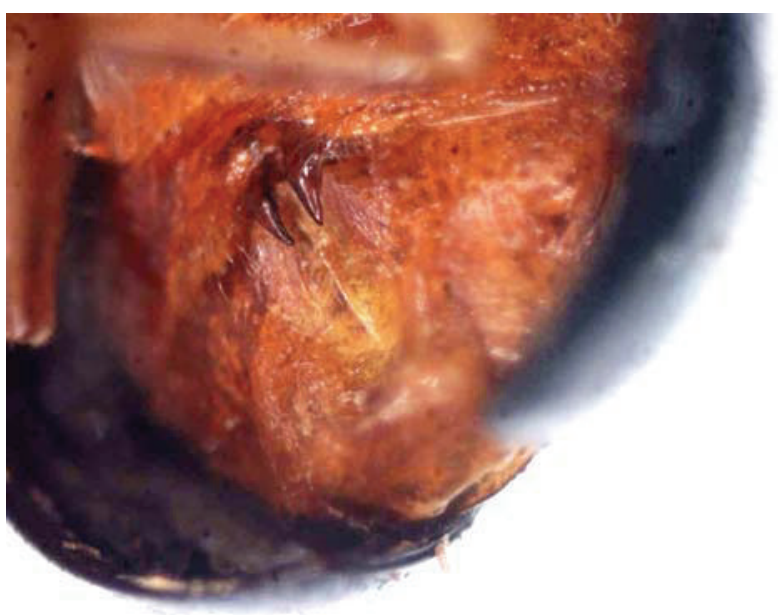

FIgURE 78: Modified abdomen: Coeligetes submetallica Jacoby.

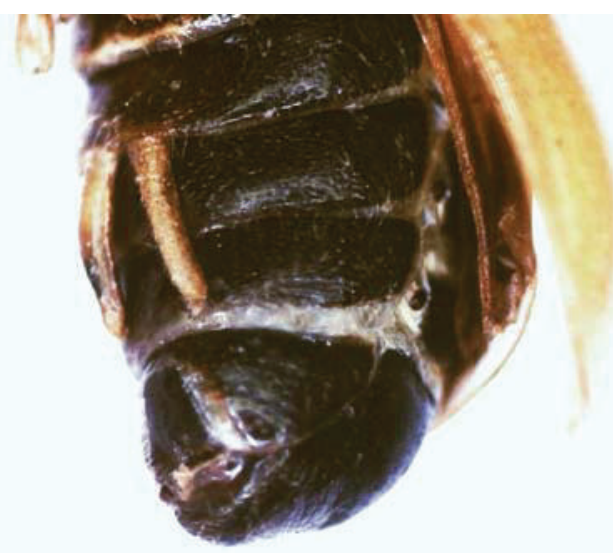

FIgURE 79: Modified abdomen: Hoplasoma unicolor (Illiger).

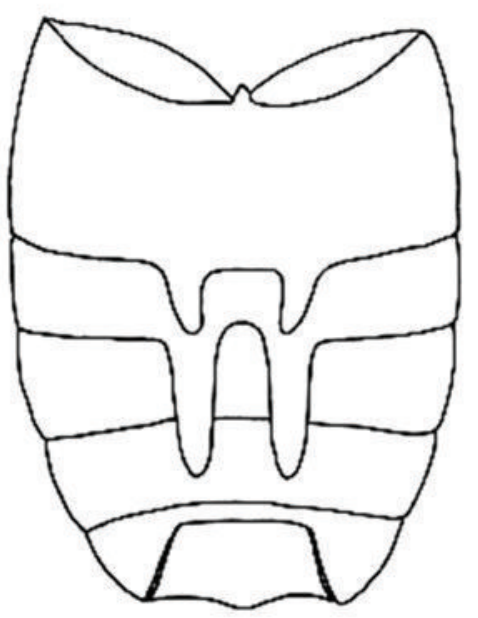

FIgure 80: Modified abdomen: Hoplasoma apicale Jacoby. 


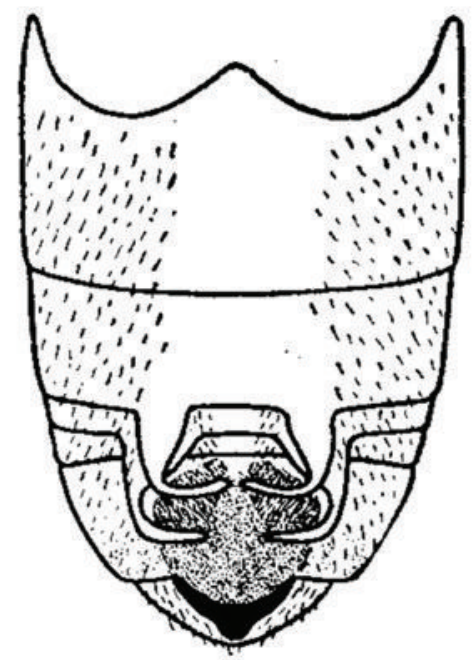

Figure 81: Modified abdomen: Androlyperus fulvus (Crotch).

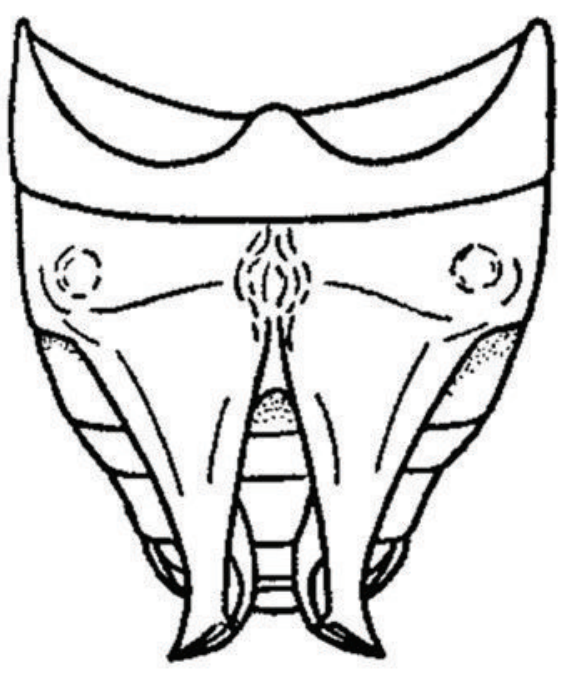

Figure 82: Modified abdomen: Scelida flaviceps (Horn).

the male, different ornaments, and therefore signal different kinds of properties in an individual [29]. Additional displays may serve to enhance the accuracy with which observers assess a single quality or serve to provide information about different qualities [30]. According to Moller and Pomiankowski [29], multiple sexual ornaments should be particularly common in taxa with the most intense sexual selection (i.e., lekking and other polygynous taxa). However, the SSCs are apparently not ornaments displayed by males to attract females. There is no variation in the SSCs among individuals within a species that would lead to intraspecific competition. Also, they are not weapons like the horns that are found in the other beetles, such as the Scarabaeidae or the jaws of Lucanidae. In these two families, the horns and jaws

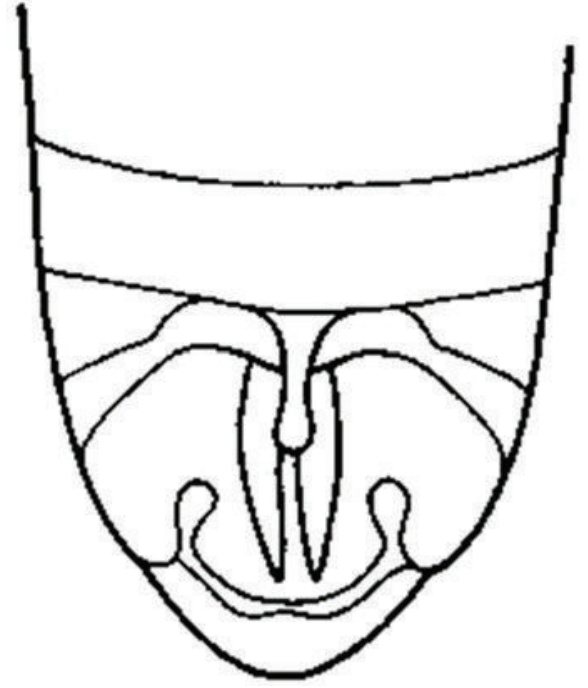

FIGURe 83: Modified abdomen: Nymphius ensifer (Guillebeau).

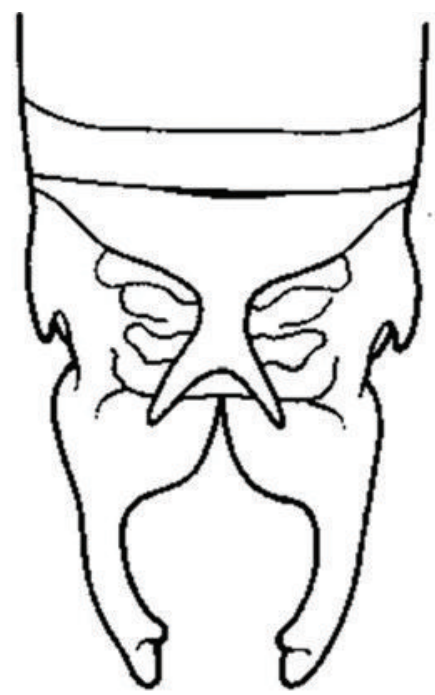

Figure 84: Modified abdomen: Nymphius forcipifer (Weise).

commonly function as weapons in the intraspecific battles [31].

The majority of the SSCs are associated with sensory and olfactory functions particularly in the antennae and to some extent in elytra where glands are formed. The other modified structures of the SSCs are associated with copulatory behavior, and in some it is suspected to be involved in sound production.

6.1. Olfaction. Olfaction begins with transduction of the information carried by odor molecules into electrical signals in sensory neurons. The odor causes species-specific signal responses by the olfactory receptor neurons. Insect odor and taste receptors are highly sensitive detectors of food, mates, and oviposition sites, and these receptors have been 


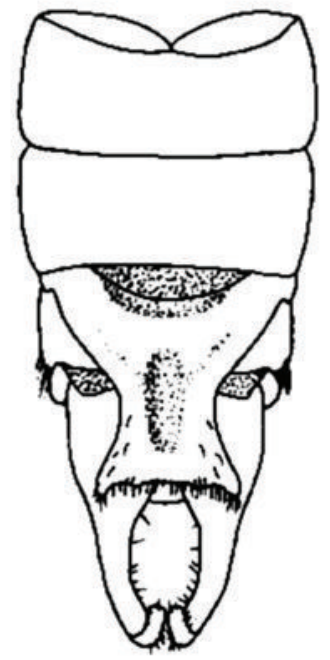

Figure 85: Modified abdomen: Nymphius gianassoi Bezděk.

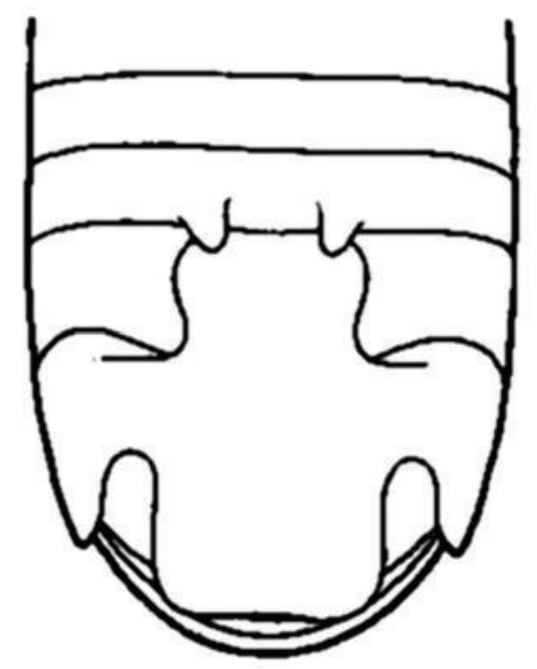

Figure 86: Modified abdomen: Nymphius lydius (Weise).

identified in several insects [32]. The sense organs act as transducers in converting chemical energy into electrical energy of nerve impulses in sensory neurons to stimulate appropriate behavioural responses, such as finding food and mate and avoiding danger.

As an olfactory organ, antennae are all provided with sensory receptors or sensillae. Usually, in a modified segment with gland, the segment is enlarged, oval, or rounded with an opening or pore, as in Cerophysa flava (Figure 18), C. gestroi (Figure 19), Metacoryna guatemalensis (Figure 20), M. fulvipes (Figure 29), Ectmesopus darlingtoni (Figure 22), and Aulacophora luteicornis (Figure 23). The same is true with some modified elytra with cavities found in Malacorhinus

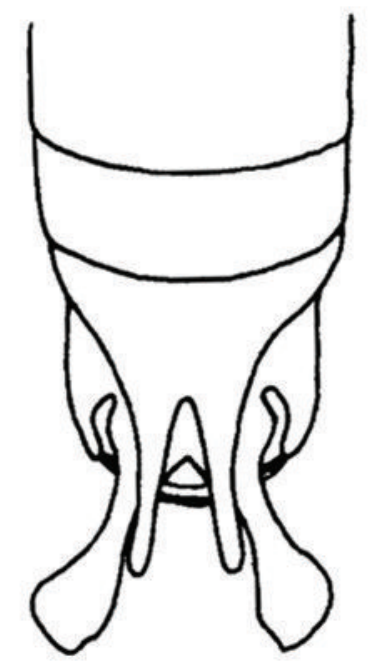

Figure 87: Modified abdomen: Nymphius ogloblini (Bogachev).

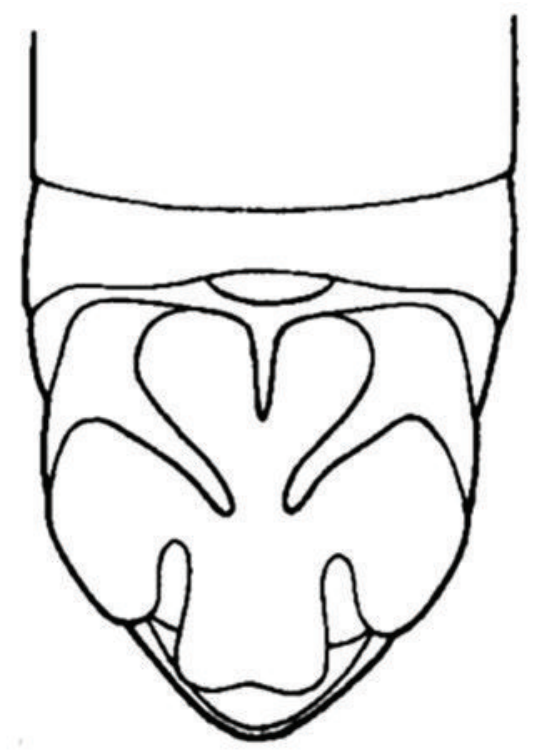

FIGURE 88: Modified abdomen: Nymphius pravei (Jacobson).

spp. (Figures 61-63) and Androlyperus nataliae (Figure 64) that bear sensillae and glands [33]. The sensory receptors are densely located in the excavated antenna of Sarawakia ajaib (Figure 12) and Cerotoma ruficornis (Figure 26), clypeus of Palpoxena spp. (Figures 5, 6, 8, and 9), and Eccoptopsis denticornis (Figure 7).

6.2. Copulatory Behavior. The SSC associated with copulatory behaviour is known as a nongenitalic male contact structure [12]. One common function of this structure is to grasp the female. The nongenitalic male structure, such as modified antennae and legs that are specialized to grasp and 


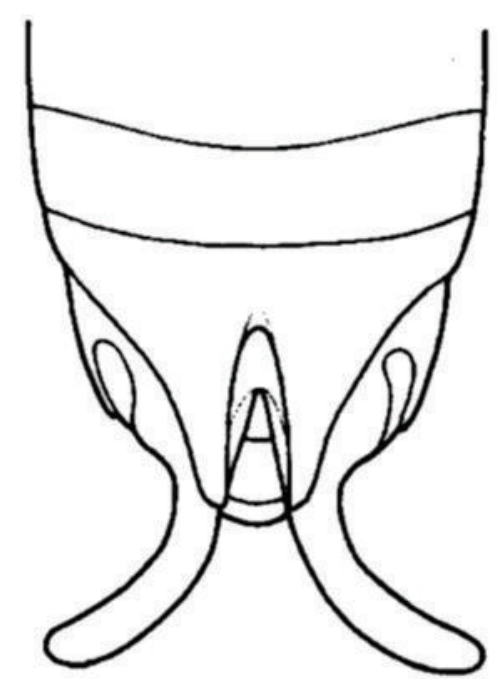

Figure 89: Modified abdomen: Nymphius stylifer (Weise).

stimulate the female, is involved in intersexual competition [13]; thus, the tight grasping by the copulating male resists any attempt by another male to dislodge the copulation.

There is a hypothesis about the interrelation between the genitalia and the secondary sexual characteristics (SSCs), wherein for a small and poorly sclerotized aedeagus, there is a provision for compensation in external structures $[12,13]$. For example, recently, Konstantinov and Korotyaev [34] suggested that the male apionid beetle (Trichoconapion hirticone (Korotyaev)) probably used the three thickened apical antennal segments as a clasping organ during copulation since it has smaller aedeagus. In the genus Aulacophora, there is a relationship between the structure of aedeagus and the presence and absence of the nongenitalic characteristics [35]. A male species with a small and poorly sclerotized aedeagus is speculated to use the enlarged modified $3 \mathrm{rd}$, 4th, and 5 th antennal segments (Figures 32 and 33) function to grasp the female during copulation. It is speculated that other species in a number of genera with large modified middle antennal segments may possibly use these as a grasping organ (Malacorhinus antennatus (Jacoby) (Figure 35), Megalognatha femoralis (Laboissiere) (Figure 38)).

This speculation is that when the leg functions as a grasping organ there is a larger body size, or there is some form of modification of the leg such as being curved or excised (emarginate or notched). The modified structures are found on various parts of the front, middle, and hind legs. Usually, only one part of a leg is modified, either the femur, tibia, tarsus, or tarsal claws. For example, if the protibia is enlarged (Mombasa magna, Figure 66, Cerotoma dilatipes, Figure 67), the protibia excised (Taumacera tibialis, Figure 68), midtibia excised (T. midtibialis, Figure 69), and the metatibia curved with a spine (Scelolyperus tejonicus, Figure 70). The modified first segment of the protarsus being enlarged or strongly dilated is also known in males of other subfamilies of Chrysomelidae; however, in the Galerucinae, the modified tarsi are extremely large and with various shapes (e.g., Taumacera yamamotoi (Figure 71)). In the genus Apophylia, the presence of bifid tarsal claws, which are appendiculate in the female, possibly functions as grasping organs.

Another nongenitalic male contact structures are found on the ventrite of the third segment of thorax, the metasternum, and the five visible abdominal sternites. In the modified metasternum, there are the median of the posterior margin, an extended process, or a pair of lobes. The function of these SSCs could possibly be associated in precopulatory behaviour; the metasternal process (Figures 73 and 74) is used by the male to stroke the female. However, the appendages on the modified abdomen (Figures 75-88) are more complex, particularly in the genus Nymphius (Figures $82-88$ ). It is also speculated that these appendages are used by the male to stroke the female during copulatory behaviour.

6.3. Sound Production. Sound produced through vibration and stridulation in animals, including insects, provides information used in predator-prey interactions, recruitment to food, mate choice, intrasexual competition, and maternal/brood social interactions [36]. Two examples from various studies on insect sound production are the termite Zootermopsis angusticollis (Hagen) that bangs its head to produce a substrate-borne vibration as an alarm signal of a disturbance to the nest by predators [37], and the leaf-cutter ant, Atta cephalotes (Linnaeus), that produces a stridulation sound using a file and scrapper mechanism for communication. Foraging workers stridulate while cutting a leaf fragment, and the stridulatory vibrations are used by the hitchhikers to locate workers engage in leaf cutting [38].

It is suspected that some of the SSCs in the Galerucinae are involved in producing sound, and that such devices are located in every part of the body, the antenna, pronotum, scutellum, elytron, leg, and abdomen [39]. Stridulation is produced by a file and scraper mechanism. Two species of Kinabalua Mohamedsaid and nine species of Xenoda Baly of the subgenus Xenoda (sensu stricto) have modified antennae with stridulatory devices. Figure 27 shows Kinabalua musaamani Mohamedsaid with antennal 8th segment bearing a long spine and 7th segment bearing a series of pegs on basal third. Xenoda species (Figures 39 and 40) has antennal segment 8 bearing a long spine and segment 9 bearing a series of pegs on the apical area. In the modified antennae mentioned above, the spine functions as a scraper and is pulled over the pegs stridulation is produced.

In some species of the following genera: Cannonia (Figure 42), Laetiacantha (Figures 44 and 45), and Prosmidia (Figure 43), the modified pronotum has a short process in the middle of the posterior margin. It is suspected that when the pronotal process (scrapper) is pulled over the surface of scutellum (file), stridulation occurs. This type of sound could also be produced by modified elytra of Prosmidia that has a pair of tubercles located at the base, between scutellum and humeri. It is speculated that during elytral movement, the basal tubercles come into contact with the posterior margin of pronotum and stridulation occurs. 
Generally, as discussed above, the modified structures found on legs are associated with copulatory behaviour. But in some Galerucinae, some are suspected to be involved in sound production using a file and scrapper mechanism. These stridulation devices are found on the metatrochanter, mesotibia, and tarsi. In the following three species Coeligetes borneensis Mohamedsaid (Figure 65), Liroeties spinipes (Oglobin), and Monolepta trochanterina Mohamedsaid, the metatrochanter bears a long pointed appendage. This trochanter which moves vertically allows the spine to rub the abdominal sternite covered with series of pegs to produce sound. In males of Momaea distincta (Figures 71(a) and 71(b)) on the middle leg, the first segment of tarsus bears a long process pointing towards an excavated area at the apex of tibia that is covered with a series of pegs. Stridulation occurs when the tarsal process (scrapper) is pulled over the series pegs on the tibia.

There are cases of modified elytra with a pair of tubercles located at the apex that are suspected to produce vibrational sound. Vibration can provide a channel of communication between males and females during mating when no stridulation occurs. The tubercle is hollow, thus when tapped on the abdomen a type of vibrational sound may be produced. It is like when one cups one's hand and taps on a surface, it produces a sound that is different compared with tapping an open hand. Amazingly, in the genus Diacantha alone, there are 81 species with males having modified elytra in a series of various-shaped tubercles. These tubercles may produce different vibrational sounds. Elytra with this type of tubercle are also found in some species of Paratriarius and one species of Sonchia.

The presence of sound production devices in some of the Galerucinae (sensu stricto) is very interesting and has great potential for future research. It had been reported in other subfamilies of the Chrysomelidae, such as the Megalopodinae, Zeugophorinae, Criocerinae, Clytrinae, Hispinae, and Cassidinae [40-42].

6.4. Unknown Function. For some SSCs, there is no apparent explanation as to their functions. The following are some examples: first antennal segment enlarged (Aulacophora cornuta (Figure 4) and Taumacera khalednordini (Figure 24)), vertex strongly broadly depressed (Monolepta flavicollis (Figure 1)), vertex longitudinally grooved (Aulacophora frontalis (Figure 2)), frons excavated with a projection (Lamprocopa spp.), clypeus transversely, deeply depressed (Cerotoma atrofasciata (Figure 3)), clypeus excavated with projections or spines (Palpoxena sumatrensis (Figure 6), Eccoptopsis denticornis (Figure 7), Palpoxena coerulipennis (Figure 9)), labrum extremely large (Palpoxena spp. (Figures 8-10)), maxillary palpi large (Palpoxena laeta (Figure 11)), larger eyes in the males of 35 species and 12 genera (Table 2), pronotum excavated with projection (Jacobya cavicollis (Figure 41)), scutellum excavated, with sides raised into high ridges (Halysacantha weisei (Jacoby)), elytra longitudinally carinate (Candezea bicostata (Figure 52)), and elytra with cavities or extrusions in Paleosepharia (Figures 54-58) and some species of Monolepta (Figure 59), Pseudocrania (Figure 60), Paridea spp., and Pseudocophora spp.

\section{Utilization of the SSC}

7.1. Identification of the Sex. The presence of SSCs has long been utilized as tool for sex identification. According to Hinton [43], a rapid and accurate method of sexing bark beetle is valuable, but the absence of SSCs in the adult confused flour beetle, Tribolium confusum Duval, and the rust-red flour beetle, $T$. castaneum Herbst, means that the beetles could only be sexed in the pupal stage, a procedure which is frequently very inconvenient. Schmitz and Furniss [44] reported the relative accuracy and usefulness of SSCs as sex indicators in Scolytus laricis Blackman. Recently, French and Hammack [45] show that the presence of SSC in the tarsal segment of corn rootworms and bean leaf beetles facilitates sex identification, which is very useful for modelling and management purposes.

7.2. Subfamily Taxonomy. There are 1298 species and 172 genera of Galerucinae with at least one type of SSC. The number of species known to have SSCs represents about 24\% of the total known Galerucinae, estimated as 5500 [2]. This is significant representation. A high number of Galerucinae with SSCs indicate a large amount of information or data that can be utilized to understand the subfamily in relation to other subfamilies of Chrysomelidae.

Taxonomically, of course, all modified structures are significant at the species level and to some extent at the generic level. Table 4 provides a summary of modified characteristics found in 49 largest genera. The modified characteristics tabulated in Table 4 are generally distinctive for the respective genera. Not much has been written about the significance of the modified characteristics at the subfamily level, except for the antennae. Jolivet [46] highlighted some Galerucinae with modified antennae and noted that compared to other Chrysomelidae this subfamily possesses the greatest diversity in antennal shape. Mohamedsaid [47] provided a general review on some modified antennae of Malaysian Galerucinae. The degree of antennal modification is much greater, not only in terms of their larger size, but also in terms of shape that to some extent may be extremely distorted or deformed. Much earlier, Maulik [17] concluded that such antennal modifications common in the Galerucinae are not found in any other subfamily, not even in the very closely allied Alticinae. However, the present study provides all types of SSCs in the form of many modified structures, including the antennae, found on all parts of the body, the head, thorax, and abdomen. A summation of all these modified characteristics documents its taxonomic significance with respect to the subfamily Galerucinae and continues to demonstrate additional differences of the Galerucinae (sensu stricto) from other subfamilies, especially the Alticinae.

There are some modified structures present in other subfamilies of Chrysomelidae, but they are not comparable in terms of representation within a subfamily and complexity of the modifications or the numbers of taxa found in the Galerucinae. This begs the question as to why this phenomenon of the SSCs is so prevalent and somewhat unique for these characters of the Galerucinae and that this may reflect its position in the Chrysomelidae. This 
SSC phenomenon is somewhat similar to the correlation of other morphological systems (e.g., aedeagus, spermatheca, and wing venation) of the Alticinae/Galerucinae that demonstrate either a Galerucinae or Alticinae tendency at the generic level [48]. Various authors have made the general statement that there are no differences between larvae of the Galerucinae (sensu stricto) and the Alticinae (sensu stricto) [49-52], but larval studies of the Galerucinae and Alticinae are far from comprehensive and without worldwide representation, that is, poor taxon sampling [53]. Besides, similarities between larvae of certain alticine and galerucine groups may be more closely tied to convergence such as habitat than to actual ancestral identity, that is, relationships [20].

An adult galerucine with the modified characteristics is clearly different from other congeneric adults without modifications. It is not known whether certain larvae of the modified adults are different from the larvae of nonmodified adults. Despite the apparently similar larval morphology, the second author has always maintained that the characteristic of the metafemoral spring (found in both sexes) is unique to and primarily defines the Alticinae, and it differentiates this subfamily from the Galerucinae (sensu stricto) [6]. This characteristic also has the very useful aspect that it can be used to distinguish genera in the vast majority of cases because of its consistent morphology in all species of each genus [54-56]. One study that tried to demonstrate that the metafemoral spring was variable within a genus [7] failed to recognize that when the spring is taken out of the metafemur and allowed to dry out its very thin chitinous structure shrivels up differently depending on many factors such as how it was treated (e.g., chemicals, temperature, etc.) during extraction; therefore, the conclusion in that reference that the metafemoral spring is not a valid intrageneric character is erroneous.

\section{Conclusion}

There are 1298 species in the subfamily Galerucinae (sensu stricto) with at least one type of sexual secondary characteristics (SSCs). This figure represents $24 \%$ of the total members of the subfamily and is a very significant number. The SSCs are so diverse, with modified structures found on every part of the body (head, thorax, and abdomen) and with functions encompassing olfactory and copulatory behaviour, as well as sound production. The presence of SSCs as stridulatory devices functioning to produce sound is certainly a significant characteristic of the subfamily Galerucinae (sensu stricto). The SSCs are not variable but are species specific. They are variable interspecifically a manifestation of amazing biodiversity of the Galerucinae with SSCs. Modified Galerucinae are unparalleled in other subfamily of the Chrysomelidae. Despite reputed larval similarities, these apomorphic characteristics of adult Galerucinae distinguish them from the Alticinae. A high representation of SSCs indicates that they are not exceptional but a characteristic of the subfamily Galerucinae (sensu stricto). These characteristics should be fully utilized in our attempt to understand the Galerucinae and its relationships with other subfamilies in the Chrysomelidae.

\section{Appendices}

\section{A. List of Galerucinae Genera Represented by at Least One Species with Secondary Sexual Character (SSC)}

(1) Acroxena Baly, 1879—clypeus, antennae, and labrum

(2) Aelianus Jacoby, 1892-antennae

(3) Afroatrachya Weise, 1904-elytra

(4) Afrocrania Hincks, 1949-clypeus, antennae, and elytra

(5) Agetocera Hope, 1840—antennae

(6) Alphidia Clark, 1865-antennae

(7) Anatela Silfverberg, 1982-abdomen

(8) Androlyperus Crotch, 1873-elytra, abdomen

(9) Anisobrotica Bechyne and Bechyne, 1969-antennae

(10) Antsianaka Duvivier, 1891-antennae

(11) Apophylia Thomson, 1858-tarsal claws, antennae, metasternum, abdomen, and tibiae

(12) Arimetus Jacoby, 1903-antennae

(13) Arthrotus Motschulsky, 1857—antennae

(14) Asbecesta Harold, 1877—antennae

(15) Atrachya Dejean, 1837-elytra

(16) Aulacophora Chevrolat, 1837—antennae, vertex, elytra, and eyes

(17) Austrotella Silfverberg, 1975-antennae and elytra

(18) Azlania Mohamedsaid, 1996-clypeus

(19) Bacteriaspis Weise, 1905-pronotum and elytra

(20) Bangprella Kimoto, 1989-antennae

(21) Bonesia Baly, 1865-antennae

(22) Buckibrotica Bechyne and Bechyne, 1969-antennae

(23) Candezea Chapuis, 1879-elytra

(24) Cannonia Hincks, 1949-pronotum and elytra

(25) Cerophysa Chevrolat, 1837-antennae and tibiae

(26) Cerophysella Laboissiere, 1930-antennae

(27) Cerotoma Chevrolat, 1837-clypeus and antennae

(28) Chapuisia Duvivier, 1885-antennae and eyes

(29) Chthoneis Baly, 1864-vertex, clypeus, antennae, and eyes

(30) Clitena Baly, 1864-antennae

(31) Cneoranidea Chen, 1942-maxillary palpi, metasternum, and abdomen

(32) Coeligetes Jacoby, 1884-abdomen and trocanthers

(33) Coelomera Chevrolat, 1837-vertex and maxillary palpi

(34) Coraia Clark, 1865-tibiae 
(35) Cornubrotica Bechyne and Bechyne, 1969-antennae, femora, and tibiae

(36) Cyclotrypema Blake, 1966-tibiae and labrum

(37) Deinocladus Blake, 1966-tibiae and antennae

(38) Dercetina Gressitt and Kimoto, 1963-antennae

(39) Diabrotica Chevrolat, 1837-antennae, maxillary palpi, and eyes

(40) Diacantha Chevrolat, 1837-elytra

(41) Dimalianella Laboissiere, 1940 — antennae

(42) Dircemella Weise, 1902—antennae

(43) Doryscus Jacoby, 1887—antennae

(44) Dreeus Shute, 1982 — antennae and tibiae

(45) Duvivieria Weise, 1903-antennae and tibiae

(46) Eccoptopsis Blake, 1966-clypeus, antennae, and tibiae

(47) Ectmesopus Blake, 1940—antennae

(48) Eleona Fairmaire, 1902-antennae and tibiae

(49) Elyces Jacoby, 1888-elytra

(50) Ephaenidea Gressitt and Kimoto, 1963-tibiae

(51) Erynephala Blake, 1936-tarsal claws

(52) Erythrobapta Weise, 1902-elytra and antennae

(53) Euliroetis Ogloblin, 1936-abdomen

(54) Eusattodera Schaeffer, 1906-clypeus

(55) Exosoma Jacoby, 1903-clypeus and antennae

(56) Fleutiauxia Laboissiere, 1933-clypeus

(57) Geinula Oglobin, 1936-antennae

(58) Gynandrobrotica Bechyne, 1955-clypeus

(59) Halysacantha Laboissiere, 1922—antennae, scutellum, and elytra

(60) Haplosomoides Duvivier, 1890—abdomen, eyes, and clypeus

(61) Hemygascelis Jacoby, 1896-abdomen

(62) Hoplasoma Jacoby, 1884-tibiae and abdomen

(63) Hoplosaenidea Laboissiere, 1933-clypeus, antennae, and tibiae

(64) Huillania Laboissiere, 1921—antennae

(65) Hylaspoides Duvivier, 1892-antennae

(66) Hymnesia Clark, 1865-antennae

(67) Hyphaenia Baly, 1865-antennae, frontal tubercles, clypeus, and eyes

(68) Hystiopsis Blake, 1966-tibiae and clypeus

(69) Inbioluperus Clark, 1993-abdomen

(70) Jacobya Weise, 1901—pronotum

(71) Japonitata Strand, 1922-antennae

(72) Kanahiiphaga Laboissiere, 1931—clypeus
(73) Kinabalua Mohamedsaid, 1997—antennae and metasternum

(74) Kumbalia Mohamedsaid and Takizawa, 2007-antennae

(75) Laetana Baly, 1864-antennae

(76) Laetiacantha Laboissiere, 1921-pronotum, elytra, and antennae

(77) Lamprocopa Hincks, 1949-frons and antennae

(78) Leptaulaca Weise, 1902-antennae and tibiae

(79) Leptoxena Baly, 1888 — antennae and femora

(80) Lesnella Laboissiere, 1931-antennae and elytra

(81) Lilophaea Bechyne, 1958-tibiae

(82) Liroetiella Kimoto, 1989-antennae

(83) Liroetis Weise, 1889-abdomen, trochanters, tibiae, and eyes

(84) Lomirana Laboissiere, 1932-elytra

(85) Luperodes Motschulsky, 1858-antennae, eyes, and tibiae

(86) Luperogala Medvedev and Samoderzhenkov, 1989abdomen

(87) Luperosoma Jacoby, 1891—antennae, abdomen, and tibiae

(88) Lygistus Wilcox, 1965-femora

(89) Macrima Baly, 1878-clypeus

(90) Mahutia Laboissiere, 1917-femora and antennae

(91) Malacorhinus Jacoby, 1887-elytra, antennae, and vertex

(92) Megalognatha Baly, 1878-antennae

(93) Metacoryna Jacoby, 1888-antennae

(94) Metopoedema Duvivier, 1891—antennae

(95) Metrobrotica Bechyne, 1958-clypeus, antennae, and tibiae

(96) Microlepta Jacoby, 1886-antennae

(97) Miltina Chapuis, 1875-antennae

(98) Mimastra Baly, 1865-abdomen

(99) Momaea Baly, 1865-tibiae

(100) Mombasa Fairmaire, 1884-tibiae

(101) Monolepta Chevrolat, 1837-elytra, vertex, and trochanters

(102) Monoleptocrania Laboissiere, 1940-vertex

(103) Neolaetana Laboissiere, 1921-antennae, pronotum, and elytra

(104) Niasia Jacoby, 1889—antennae

(105) Nirina Weise, 1892 — antennae

(106) Nirinoides Jacoby, 1903-antennae

(107) Nymphius Weise, 1900—abdomen

(108) Oidomorpha Laboissiere, 1924-antennae 
(109) Oorlogia Silfverberg, 1978-antennae

(110) Ornithognathus Thomson, 1858-antennae

(111) Oroetes Jacoby, 1888-antennae, clypeus, pronotum, and tibiae

(112) Orthoxia Clark, 1865-antennae

(113) Paleosepharia Laboissiere, 1936-pronotum and elytra

(114) Palpaenidea Laboissiere, 1933—clypeus and antennae

(115) Palpoxena Baly, 1861—clypeus, labrum, maxillary palpi, and antennae

(116) Parabrotica Bechyne and Bechyne, 1961-antennae and tibiae

(117) Paracanthina Hincks, 1949_-pronotum and elytra

(118) Paraplotes Laboissiere, 1933-antennae

(119) Parasbecesta Laboissiere, 1940_antennae

(120) Paratriarius Schaeffer, 1906-antennae and elytra

(121) Paridea Baly, 1886-elytra

(122) Periclitena Weise, 1902_antennae

(123) Phyllecthris Dejean, 1837-antennae and tibiae

(124) Phyllobrotica Chevrolat, 1837-antennae, femora, and abdomen

(125) Phyllobroticella Jacoby, 1894-antennae and elytra

(126) Pimentelia Laboissiere, 1939_antennae

(127) Platybrotica Cabrera and Walsh, 2004-antennae

(128) Platymorpha Jacoby, 1888-tibiae

(129) Platyxantha Baly, 1864 - antennae, tibiae, and eyes

(130) Porechontes Blake, 1966-clypeus, antennae, and tibiae

(131) Prosmidia Weise, 1901-pronotum, scutellum, and elytra

(132) Pseudaenidea Laboissiere, 1938-clypeus

(133) Pseudocophora Jacoby, 1884-elytra

(134) Pseudocrania Weise, 1892-elytra

(135) Pseudoluperus Beller and Hatch, 1932-abdomen

(136) Pseudorupilia Jacoby, 1893-antennae

(137) Pseudoscelida Jacoby, 1894-antennae and eyes

(138) Pseudoshaira Beenen, 2007-antennae

(139) Rachicephala Blake, 1966-clypeus

(140) Rohaniella Laboissiere, 1940-eyes and antennae

(141) Ruwenzoria Laboissiere, 1919-antennae

(142) Samoria Silfverberg, 1982-antennae

(143) Sarawakiola Mohamedsaid, 1997-antennae and vertex

(144) Scelida Chapuis, 1875-abdomen and tibiae

(145) Scelidacne Clark, 1998-abdomen and tibiae
(146) Scelolyperus Crotch, 1874-tibiae

(147) Schematiza Chevrolat, 1837-antennae

(148) Sermyloides Jacoby, 1884—clypeus and antennae

(149) Sesselia Laboissiere, 1931-antennae

(150) Shungwayana Silfverberg, 1975-antennae

(151) Sikkimia Duvivier, 1891—antennae

(152) Simopsis Blake, 1966-antennae and tibiae

(153) Sinoluperoides Kimoto, 1989—antennae

(154) Sonchia Weise, 1901-elytra

(155) Spilocephalus Jacoby, 1888-clypeus

(156) Spilonotella Cockerell, 1905-antennae

(157) Stenellina Cockerell, 1905-antennae

(158) Stenoplatys Baly, 1861—antennae and tibiae

(159) Strobiderus Jacoby, 1884-elytra

(160) Synetocephalus Fall, 1910 — antennae and tibiae

(161) Taenala Silfverberg, 1978 — antennae and pronotum

(162) Taphinella Jacoby, 1899-antennae

(163) Taumacera Thunberg, 1814-antennae, metasternum, clypeus, and tibiae

(164) Taumaceroides Lopatin, 2009-antennae, femora, and tibiae

(165) Theopea Baly, 1864-clypeus and antennae

(166) Therpis Weise, 1900-antennae

(167) Trichobrotica Bechyne, 1956-tibiae

(168) Trichomimastra Weise, 1922—antennae

(169) Vitruvia Jacoby, 1903-antennae

(170) Xenarthra Baly, 1861-antennae

(171) Xenoda Baly, 1877-antennae

(172) Zinjotella Silfverberg, 1975-antennae and elytra

\section{B. List of Galerucinae (Sensu Stricto) with Secondary Sexual Characters (SSCs)}

(1) Acroxena clypeata (Baly, 1888)-clypeus excavated, with a median projection; labrum large; antennae $3 \mathrm{rd}, 4$ th, and 5 th thickened

(2) A. femoralis Kimoto, 1989-clypeus excavated; antennae 1st enlarged, 3rd thickened

(3) A. fulva Kimoto, 1989-clypeus transversely excavated, with tuft of hairs; antennae 1st enlarged, 3rd thickened

(4) A. indica Jacoby, 1896-clypeus deeply excavated, with a median projection; labrum large subtriangular; antennae 3rd-10th under surface covered with long erect hairs

(5) A. nasuta Baly, 1879-clypeus slightly excavated, with two median projections; labrum large, concave, with tuft of hairs; antennae 3rd, 4th, 5th, and 6th thickened 
(6) Aelianus scutellatus Jacoby, 1892-antennae dilated, covered with long hairs

(7) Afroatrachya impressus (Weise, 1904)-elytra with postscutellar cavities

(8) Afrocrania aequatoriana Wagner, 2007-elytra with a shallow heart-shaped postscutellar depression

(9) A. assimilis (Weise, 1903)_clypeus deeply excavated; antennae 4th curved, with long distal edge

(10) A. famularis (Weise, 1904)_elytra with small subscutellar markings, visible as dense micro-sculpture

(11) A. foveolata (Karsch, 1882)—clypeus deeply excavated; antennae 4 th and 5 th each with a long distal edge

(12) A. kaethae Middelhauve and Wagner, 2001—clypeus shallowly excavated; antennae 4 th curved, with a long distal edge

(13) A. kakamegaensis Middelhauve and Wagner, 2001elytra excavated at base, with two small protruding bulges, and at the middle with oval shaped elevation and shallowed groove

(14) A. latifrons Weise, 1892-clypeus deeply excavated; antennae 4 th curved inwards

(15) A. longicornis Middelhauve and Wagner, 2001elytra with longitudinal postscutellar extrusions

(16) A. luciae Middelhauve and Wagner, 2001-clypeus unevenly, deeply excavated; antennae 4 th curved with a long distal edge

(17) A. nigra Wagner, 2007-elytra with a small heartshaped postscutellar depression

(18) A. occidentalis Wagner, 2007-elytra with a keel-like postscutellar extrusion and shallow depression

(19) A. pallida Wagner, 2007-elytra with a shadow-like spot in basal half

(20) A. pauli (Weise, 1903)_elytra with a small humpbacked postscutellar extrusion

(21) A. ubatubae Middelhauve and Wagner, 2001-elytra with a shallow depression

(22) A. weisei Wagner, 2007-elytra with postscutellar extrusion keel-liked and a shallow drop-shaped depression

(23) Agetocera abdominalis Jiang, 1992-antennae 8th extremely larged, 9th curved, 10th and 11th elongated, clyndrical

(24) A. birmanica Jacoby, 1891-antennae 8th extremely large, excavated, 9th large, triangularly expanded

(25) A. biclava Zhang and Yang, 2005-antennae 8th very large, excavated, 9th enlarged, cylindrical

(26) A. carinicornis Chen, 1964-antennae 8th large, with a hook at apex, 9th thickened, short

(27) A. chapana Laboissiere, 1929-antennae 8th very large, oblong, 9th subcylindrical, excavated
(28) A. choui Lee, Bezděk, and Staines, 2010-antennae 8th strongly swollen, pointed at apex, 9th large, excavated

(29) A. deformicornis (Laboissiere, 1927)—antennae 8th very large, with a prominent spine, 9th extremely large, deformed

(30) A. discedens Weise, 1922-antennae 8th extremely large, elongate triangular, 9th outwardly inserted on 8th, cylindrical, twisted at base

(31) A. femoralis Chen, 1942-antennae 8th enlarged, cylindrical, 9th enlarged

(32) A. flaviventris Jacoby, 1879-antennae 8th very large, ovate, 9th smaller, excavated

(33) A. hopei Baly, 1865-antennae 8th very large, funnelshaped, 9th excavated, with a very strong protuberance at base

(34) A. huatungensis Lee, Bezděk, and Staines, 2010antennae 8th strongly swollen pointed at apex, 9th excavated

(35) A. lobicornis Baly, 1865-antennae 8th small, funnel shaped, 9th extremely large, excavated

(36) A. manipuria Maulik, 1936-antennae 8th very large, oblong, excavated, 9th large, excavated

(37) A. mirabilis (Hope, 1831) —antennae 8th extremely large, oblong, 9th smaller, with basal half larger than the apical

(38) A. nigripennis Laboissiere, 1927-antennae 9th large subcylindrical, 10th deeply excavated at middle, Cshaped

(39) A. orientalis Weise, 1902-antennae 8th large, subcylindrical, 9th large, angulate

(40) A. silva Bezděk, 2010-antennae 9th extremely large, with tooth at apical angle

(41) A. similes Chen, 1964-antennae 8th enlarged, 9th curved, U shaped

(42) A. taiwana Chujo, 1962-antennae 8th enlarged, excavated, pointed at apex, 9th enlarged, triangular

(43) A. yuae Lee, Bezděk, and Staines, 2010 — antennae 8th strongly swollen, pointed at apex, 9th large, excavated

(44) A. yunnana Chen, 1964-antennae 9th extremely large, excavated

(45) Alphidia comitata (Klug, 1833)—antennae 5th-8th dilated

(46) Anatela transverfasciata (Laboissiere, 1921)abdomen 1st with a short and blunt knob-like appendage

(47) Androlyperus californicus (Schaeffer, 1906)—elytra with deep incision at apical angle

(48) A. fulvus Crotch, 1873-elytra with deep incision at apical angle; abdomen 2 nd and 3 rd each with a pair of long appendages 
(49) A. incisus (Schaeffer, 1906)—elytra with deep incision at apical angle

(50) A. maculatus Leconte, 1883-elytra with deep incision at apical angle

(51) A. nataliae Clark, 1999-elytra with deep incision at apical angle

(52) A. nigrescens (Schaeffer, 1906)—elytra with deep incision at apical angle

(53) Anisobrotica donckieri (Baly, 1889)—antennae 9th, 10th, and 11th broadened, excavated; front tibiae emarginate

(54) A. nordenskioldi (Jacoby, 1904)—antennae 9th, 10th, and 11th broadened, excavated; front tibiae emarginate

(55) Antsianaka pulchella Duvivier, 1891—antennae extremely long, 1st swollen at apex

(56) Apophylia abdominalis Laboissiere, 1929-tarsal claws bifid

(57) A. allaudi Allard, 1888-tarsal claws bifid

(58) A. aeruginosa (Hope, 1831) — tarsal claws bifid; abdomen 1st and 2nd, each with a pair of appendages

(59) A. algie Bezděk, 2008-tarsal claws bifid

(60) A. angolensis Laboissiere, 1921 — tarsal claws bifid

(61) A. angustata Allard, 1889-tarsal claws bifid

(62) A. asahinai Chujo, 1962-tarsal claws bifid

(63) A. assamensis (Jacoby, 1891) — tarsal claws bifid

(64) A. aurolimbata Allard, 1888-tarsal claws bifid

(65) A. basilana Pic, 1945-tarsal claws bifid; metasternum with a small tubercle

(66) A. beeneni Bezděk, 2003-tarsal claws bifid; metasternum with a small tubercle

(67) A. bertiae Bezděk, 2003-tarsal claws bifid; antennae 1 st-5th covered with very long hairs; metasternum with a large tubercle

(68) A. bifasciata Allard, 1889-tarsal claws bifid

(69) A. blecha Bezděk, 2008-tarsal claws bifid

(70) A. borowiecki Bezděk, 2004-tarsal claws bifid

(71) A. brancucci Medvedev and Sprecher, 1999-tarsal claws bifid

(72) A. carinata Laboissiere, 1922-tarsal claws bifid

(73) A. celebensis Pic, 1927-tarsal claws bifid; metasternum with a bifurcate process

(74) A. cervenki Bezděk, 2005-tarsal claws bifid

(75) A. cheni Bezděk and Zhang, 2006-tarsal claws bifid

(76) A. chloroptera Thomson, 1858-tarsal claws bifid; mesotarsi 1st with deeply incised

(77) A. clavareaui Laboissiere, 1940-tarsal claws bifid

(78) A. clavicornis Samoderzhenkov, 1988-tarsal claws bifid; antennae 9th, 10th, and 11th strongly dilated
(79) A. clypeata Samoderzhenkov, 1988-tarsal claws bifid

(80) A. consanguinea Allard, 1889-tarsal claws bifid

(81) A. crassicornis Laboissiere, 1920-tarsal claws bifid; antennae 4th-7th dilated

(82) A. curvipes Laboissiere, 1920-tarsal claws bifid; metatibiae curved

(83) A. cyaneolimbata Laboissiere, 1922-tarsal claws bifid

(84) A. cyanipennis Laboissiere, 1927—-tarsal claws bifid

(85) A. dellacasai Bezděk, 2006-tarsal claws bifid

(86) A. dembickyi Bezděk, 2006-tarsal claws bifid

(87) A. demeyeri Bezděk, 2005-tarsal claws bifid; antennae 5 th enlarged

(88) A. denisae Bezděk, 2005-tarsal claws bifid

(89) A. dilaticornis (Jacoby, 1894)—tarsal claws bifid; antennae 3rd and 4th enlarged, oblong, 5th-7th enlarged, dilated at apex

(90) A. disconotata Pic, 1947—tarsal claws bifid

(91) A. elongata (Jacoby, 1896)—-tarsal claws bifid

(92) A. elschotziae Chen, 1976-tarsal claws bifid; antennae 8th enlarged

(93) A. eoa Oglobin, 1936-tarsal claws bifid

(94) A. epipeluralis Laboissiere, 1927-tarsal claws bifid

(95) A. eroshkinae Samoderzhenkov, 1988-tarsal claws bifid

(96) A. excavata Bryant, 1954-tarsal claws bifid

(97) A. femorata (Jacoby, 1895) — tarsal claws bifid

(98) A. flavovirens (Fairmaire, 1878)—-tarsal claws bifid

(99) A. frischi Bezděk, 2003-tarsal claws bifid

(100) A. furcigera Chujo, 1962-tarsal claws bifid; metasternum with a long bifurcate process

(101) A. ghesquierei Laboissiere, 1940 — tarsal claws bifid

(102) A. gloriosa Laboissiere, 1922-tarsal claws bifid

(103) A. grandicornis (Fairmaire, 1888) — tarsal claws bifid

(104) A. grobbelaarae Bezděk, 2006-tarsal claws bifid

(105) A. hajeki Bezděk, 2003-tarsal claws bifid; abdomen 1 st and 2nd, each with a pair of appendages

(106) A. haladai Bezděk, 2006-tarsal claws bifid

(107) A. halberstadti Baezdek, 2006-tarsal claws bifid

(108) A. hanka Bezděk, 2005-tarsal claws bifid

(109) A. hebes Weise, 1904-tarsal claws bifid; metasternum with a bifurcate process; metafemora very large

(110) A. holosericea Laboissiere, 1925-tarsal claws bifid

(111) A. incisitarsis (Laboissiere, 1922)—-tarsal claws bifid; antennae 5th greatly enlarged

(112) A. jeanneli Laboissier, 1921-tarsal claws bifid

(113) A. jolantae Bezděk, 2007-tarsal claws bifid

(114) A. kaffa Bezděk, 2005-tarsal claws bifid 
(115) A. kantneri Bezděk, 2003-tarsal claws bifid; antennae 3 rd-7th dilated

(116) A. kaoi Bezděk and Lee, 2009_tarsal claws bifid

(117) A. keniaensis Laboissiere, 1920—-tarsal claws bifid

(118) A. kimotoi Bezděk, 2003-tarsal claws bifid

(119) A. kubani Bezděk, 2005-tarsal claws bifid; antennae 9th, 10th, and 11th dilated

(120) A. laotica Bezděk, 2005-tarsal claws bifid

(121) A. laticollis Laboissiere, 1922-tarsal claws bifid; antennae 4 th -7 th dilated

(122) A. lebongana Maulik, 1936-tarsal claws bifid; antennae 3rd-7th dilated, funnel shaped, 9th dilated, triangular; abdomen 1st with a pair of short appendages

(123) A. leontovitchi Laboissiere, 1940—tarsal claws bifid; antennae 5 th enlarged

(124) A. lesnei Laboissiere, 1922-tarsal claws bifid

(125) A. levi Bezděk, 2004-tarsal claws bifid; antennae 9th, 10 th, and 11th strongly dilated

(126) A. libenae Bezděk, 2007-tarsal claws bifid

(127) A. lindae Bezděk, 2006-tarsal claws bifid

(128) A. liska Bezděk, 2008_tarsal claws bifid

(129) A. luzonica Bezděk, 2003-tarsal claws bifid

(130) A. maculata Kimoto, 1977-tarsal claws bifid

(131) A. maculicollis (Jacoby, 1895)—-tarsal claws bifid; metasternum with a small tubercle

(132) A. marginata Jacoby, 1899-tarsal claws bifid

(133) A. marginicollis Laboissiere, 1940—-tarsal claws bifid

(134) A. marginipennis Weise, 1922-tarsal claws bifid

(135) A. marketae Bezděk, 2006-tarsal claws bifid

(136) A. marshalli (Jacoby, 1897)—-tarsal claws bifid

(137) A. matrensi Bezděk, 2003-tarsal claws bifid

(138) A. mauritanica Pic, 1944-tarsal claws bifid

(139) A. maynei Labossiere, 1922-tarsal claws bifid; metatibiae curved

(140) A. medvedevi Samoderzhenkov, 1988-tarsal claws bifid

(141) A. melli Gressitt and Kimoto, 1963-tarsal claws bifid

(142) A. metallica Jacoby, 1904-tarsal claws bifid

(143) A. micheli Bezděk, 2001—tarsal claws bifid; abdomen 1 st and 2 nd, each with a pair of short appendages

(144) A. mikhailovi Bezděk, 2003-tarsal claws bifid; metasternum with a large tubercle

(145) A. mila Bezděk, 2005-tarsal claws bifid

(146) A. mimica Samoderzhenkov, 1988-tarsal claws bifid

(147) A. miyamotoi Kimoto, 1969-tarsal claws bifid

(148) A. neavei Bezděk, 2005-tarsal claws bifid

(149) A. nepalica Bezděk, 2003-tarsal claws bifid
(150) A. nigriceps Laboissiere, 1927-tarsal claws bifid

(151) A. nigricollis Allard, 1888-tarsal claws bifid

(152) A. nigrolimbata Laboissiere, 1940—-tarsal claws bifid

(153) A. nilakrishna Maulik, 1936-tarsal claws bifid; antennae 5th-7th dilated; abdomen 1 st and 2 nd, each with a pair of appendages

(154) A. nobilitata Gerstaecker, 1871-tarsal claws bifid; metasternum with a bifurcate process

(155) A. nodicornis Laboissiere, 1922-tarsal claws bifid; antennae 5 th extremely large

(156) A. oborili Bezděk, 2005-tarsal claws bifid

(157) A. pacholatkoi Bezděk, 2005-tarsal claws bifid; antennae 9th, 10th, and 11th dilated

(158) A. pallipes (Jacoby, 1892) — tarsal claws bifid; antennae 9 th, 10th, and 11th strongly dilated

(159) A. pavlae Bezděk, 2003-tarsal claws bifid

(160) A. pectoralis Pic, 1927-tarsal claws bifid; metasternum with a bifurcate process

(161) A. pesai Bezděk, 2006-tarsal claws bifid

(162) A. phuphanensis Bezděk, 2006-tarsal claws bifid

(163) A. poggii Bezděk, 2003-tarsal claws bifid

(164) A. porraceipennis (Allard, 1889)—tarsal claws bifid

(165) A. pulchella Bryant, 1952-tarsal claws bifid

(166) A. purpurea (Allard, 1888)—tarsal claws bifid; metafemora enlarged

(167) A. quadristigmata Laboissiere, 1922-tarsal claws bifid

(168) A. raffrayi Pic, 1946-tarsal claws bifid

(169) A. rugiceps Gressitt and Kimoto, 1963-tarsal claws bifid

(170) A. saliens Weise, 1904-tarsal claws bifid; metasternum with a bifurcate process; metafemora very large

(171) A. samoderzhenkovi Medvedev, 1993-tarsal claws bifid

(172) A. savioi Pic, 1931-tarsal claws bifid

(173) A. schawalleri Medvedev, 1992-tarsal claws bifid; abdomen 1st with a pair of short appendages

(174) A. securigera Chujo, 1962-tarsal claws bifid

(175) A. semiobscura Faimaire, 1887-tarsal claws bifid

(176) A. sericea (Fabricius, 1798)—-tarsal claws bifid

(177) A. shuteae Bezděk, 2003-tarsal claws bifid

(178) A. sikkimensis Bezděk, 2003-tarsal claws bifid

(179) A. similis Weise, 1909—-tarsal claws bifid

(180) A. snizeki Bezděk, 2005-tarsal claws bifid; metasternum with a bifurcate process

(181) A. sosia Laboissiere, 1940—tarsal claws bifid

(182) A. sprecherae Bezděk, 2003-tarsal claws bifid 
(183) A. sulcata Laboissiere, 1922-tarsal claws bifid

(184) A. taiwanica Bezděk, 2003-tarsal claws bifid

(185) A. takizawai Bezděk, 2005-tarsal claws bifid

(186) A. tarsalis Laboissiere, 1938-tarsal claws bifid

(187) A. thalassina Faldermann, 1835-tarsal claws bifid

(188) A. trapezicollis Laboissiere, 1940-tarsal claws bifid

(189) A. trinotata Gressitt and Kimoto, 1963-tarsal claws bifid

(190) A. trochanterina Gressitt and Kimot, 1963-tarsal claws bifid

(191) A. velai Bezděk, 2003-tarsal claws bifid

(192) A. variicollis Laboissiere, 1922-tarsal claws bifid

(193) A. vernalis (Allard, 1889)—-tarsal claws bifid

(194) A. vicinia Laboissiere, 1940_-tarsal claws bifid

(195) A. vietnamica Samoderzhenkov, 1988-tarsal claws bifid

(196) A. viridipennis (Jacoby, 1885)—tarsal claws bifid

(197) A. viridis (Jacoby, 1884)—-tarsal claws bifid

(198) A. voriseki Bezděk, 2003-tarsal claws bifid

(199) A.weisei (Jacoby, 1896)—tarsal claws bifid

(200) A. wittei Laboissiere, 1940_tarsal claws bifid

(201) A. yangi Bezděk and Zhang, 2006-tarsal claws bifid

(202) A. yunnanica Bezděk, 2003-tarsal claws bifid

(203) A. zoiai Bezděk, 2005-tarsal claws bifid

(204) Arimetus conradti Jacoby, 1903-antennae 5th-11th thickened

(205) A. costulatus Laboissiere, 1922-antennae 4th-11th thickened

(206) Arthrotus hijau Mohamedsaid, 2001—antennae with long hairs

(207) A. histrio (Baly, 1879)_antennae 3rd small, globular

(208) Asbecesta antennalis Weise, 1912-antennae 6th-9th thickened

(209) A. bifasciata Laboissiere, 1919-antennae 6th-9th thickened

(210) A. biplagiata Jacoby, 1895-antennae 4th-10th thickened

(211) A. breviuscula Weise, 1904-antennae 6th, 7th, and 8th thickened

(212) A. capensis Allard, 1888-antennae 6th-10th thickened

(213) A. carinata Laboissiere, 1931-antennae 6th-9th thickened

(214) A. commoda Weise, 1906-antennae 6th-9th thickened

(215) A. congoensis Laboissiere, 1929-antennae 6th-9th thickened
(216) A. costalis Weise, 1912-antennae 8th, 9th, and 10th thickened

(217) A. feai Laboissiere, 1937-antennae 6th, 7th, and 8th thickened

(218) A. festiva Laboissiere, 1919-antennae 6th-9th thickened

(219) A. hintzi Weise, 1901-antennae 6th-9th thickened

(220) A. lesnei Laboissiere, 1931-antennae 7th, 8th, and 9 th thickened

(221) A. marginata Jacoby, 1899-antennae 2nd-10th thickened

(222) A. monardi Laboissiere, 1931-antennae 7th, 8th, and 9th thickened

(223) A. nigripes Bryant, 1958 - antennae 6th, 7th, and 8th thickened

(224) A. ruwensorica Weise, 1912-antennae 6th-10th thickened

(225) A. semicincta Laboissiere, 1919-antennae 6th-10th thickened

(226) A. terminalis Weise, 1901-antennae 2nd-10th thickened, with 7 th, 8 th, and 9 th dilated

(227) A. variabilis Weise, 1895-antennae 6th-9th thickened

(228) Atrachya bimaculata (Hornstedt, 1788)—elytra with elongate postscutellar cavities

(229) A. foveolatus (Laboissiere, 1919) - elytra with oval shaped postscutellar cavities

(230) A. impressipennis (Jacoby, 1890)—elytra with elongate postscutellar cavities

(231) A. menetriesi (Faldermann, 1835)—elytra with elongate postscutellar cavities

(232) A. somaliensis (Laboissiere, 1937)—elytra with triangular shaped postscutellar cavities

(233) Aulacophora abdominalis (Fabricius, 1871)antennae 1st enlarged; humeri with erect hairs

(234) A. analis (Weber, 1801) - antennae 3rd, 4th, and 5th enlarged

(235) A. antennata Baly, 1886-antennae 11th enlarged, pointed at apex

(236) A. apicicornis Baly, 1889-antennae 11th enlarged, pointed at apex

(237) A. baliensis Barroga, 2001-antennae 3rd, 4th, and 5 th enlarged; vertex with a pair of oblique ridges

(238) A. basalis Jacoby, 1886-antennae 11th enlarged, pointed at apex

(239) A. bicolor (Weber, 1801)-antennae 4th-11th covered with erect hairs

(240) A. bipartita Baly, 1888-antennae 3rd, 4th, and 5th enlarged; vertex with a pair of oblique ridges

(241) A. bipunctata (Olivier, 1808)_antennae 1st enlarged, with sharp edge 
(242) A. blackburni Bowdicth, 1914-antennae 3rd, 4th, and 5th enlarged

(243) A. borneensis Barroga and Mohamedsaid, 2000antennae 11th enlarged, deeply excavated ending with two points; maxillary palpi swollen

(244) A. cavicollis Fairmaire, 1880-antennae 3rd, 4th, and 5th thickened

(245) A. cincta (Fabricius, 1775) - antennae 3rd, 4th, and 5 th enlarged; vertex excavated

(246) A. circumdata Allard, 1899-antennae 3rd, 4th, and 5 th enlarged

(247) A. coffeae (Hornstedt, 1788)-antennae 4th-11th covered with erect hairs

(248) A. cornuta Baly, 1879-antennae 1st enlarged; clypeus excavated, with a pair of spines

(249) A. crassicornis Medvedev, 2001-antennae 3rd, 4th, and 5 th enlarged

(250) A. danumensis Mohamedsaid, 1994-antennae 11th enlarged, pointed at apex; maxillary palpi swollen; eyes large

(251) A. diversa Baly, 1889-antennae 2nd-6th enlarged, longitudinally ridged; maxillary palpi swollen

(252) A. dohertyi Bowditch, 1925-antennae 3rd, 4th, and 5 th enlarged

(253) A. dulitensis Barroga and Mohamedsaid, 2002antennae 2 nd-7th enlarged

(254) A. fauveli Beenen, 2008-antennae 1st enlarged; humeri with erect hairs

(255) A. flavomarginata Duvivier, 1884-antennae 3rd, 4 th, and 5 th enlarged

(256) A. foveata Bowditch, 1925-antennae 3rd, 4th, and 5 th enlarged

(257) A. foveicollis (Lucas, 1849)—antennae 1st enlarged; humeri with erect hairs

(258) A. fraudulenta Jacoby, 1886-antennae 3rd, 4th, and 5 th enlarged

(259) A. frontalis Baly, 1888-antennae 3rd, 4th, and 5th enlarged; vertex with a pair of longitudinal ridges

(260) A. hilaris (Boisduval, 1835)—antennae 3rd, 4th, and 5 th enlarged

(261) A. impressa (Fabricius, 1801)—antennae 1st enlarged; pronotum deeply excavated

(262) A. indica (Gmelin, 1790)_antennae 1st enlarged; humeri with erect hairs

(263) A. insularis Jacoby, 1886 - antennae 3rd, 4th, and 5th thickened

(264) A. irpa Mohamedsaid, 1994-antennae 3rd-11th longitudinally ridged; maxillary palpi swollen; eyes large

(265) A. jacobyi (Weise, 1896) - antennae 3rd, 4th, and 5th enlarged; vertex with a pair of perpendicular ridges
(266) A. kinabaluensis Mohamedsaid, 1994-antennae 11th enlarged, pointed at apex; maxillary palpi swollen

(267) A. laevifrons Baly, 1888 - antennae 3rd, 4th, and 5th enlarged

(268) A. laysi Medvedev, 2001-antennae 3rd, 4th, and 5th enlarged; vertex with a pair of longitudinal ridges

(269) A. lewisii Baly, 1886-antennae 3rd, 4th, and 5th thickened

(270) A. loochooensis Chujo, 1957-antennae 3rd enlarged

(271) A. luteicornis (Fabricius, 1801)-antennae 11th enlarged, deeply excavate ending with two points

(272) A. martia (Weise, 1922) - antennae 3rd, 4th, and 5th enlarged; vertex with a pair of oblique ridges

(273) A. mimica Medvedev, 2001-antennae 3rd, 4th, and 5 th enlarged; vertex with a pair of oblique ridges

(274) A. nigroplagiata Jacoby, 1894-antennae 3rd, 4th, and 5th enlarged

(275) A. olivieri Baly, 1888-antennae 3rd, 4th, and 5th enlarged

(276) A. orientalis (Hornstedt, 1788) —antennae 3rd, 4th, and 5 th enlarged; vertex with a pair of oblique ridges

(277) A. palliata (Schaller, 1783)—antennae 3rd, 4th, and 5th enlarged; vertex with a transverse ridge

(278) A. quadrimaculata (Fabricius, 1781)—antennae 3rd, 4 th, and 5 th enlarged

(279) A. quadrinotata (Chapuis, 1876) —antennae 3rd-6th enlarged

(280) A. quadripartita (Fairmaire, 1877)—antennae 3rd, 4 th, and 5 th enlarged

(281) A. robusticornis Medvedev, 2001-antennae 3rd, 4th, and 5th enlarged

(282) A. sarawakiensis Barroga and Mohamedsaid, 2002antennae 3rd-7th longitudinally ridged

(283) A. sulaksonoi Mohamedsaid, 2009-antennae 1st enlarged, humeri with rows of erect hairs

(284) A. tricolora (Weise, 1892) - antennae 3rd, 4th, and 5 th enlarged; vertex with a pair of oblique ridges

(285) A. tristis Medvedev, 2001 — antennae 3rd, 4th, and 5th enlarged

(286) A. vittula (Chapuis, 1876)—antennae 3rd, 4th, and 5 th enlarged; vertex with a pair of longitudinal ridges

(287) A. weisei Barroga and Mohamedsaid, 2002antennae 3rd, 4th, and 5th enlarged; vertex with a pair of oblique ridges

(288) Austrotella lugubris (Peringuey, 1892)-antennae 3rd-7th dilated towards apex, flattened; elytra with scutellar area elevated

(289) A. vulpecula Silfverberg, 1975-antennae 3rd-7th dilated towards apex; elytra with scutellar area elevated 
(290) Azlania apicalis Mohamedsaid, 1996-clypeus excavated, with a pair of spines in front of antennae and a pair of lateral ridges near mandibles

(291) A. borneensis Mohamedsaid, 1996-clypeus excavated, with a pair of tuft hairs in front of antennae and a pair of large tubercles near mandibles

(292) A. costatipennis (Jacoby, 1896)—clypeus excavated, with a pair of spines in front of antennae and a pair of tubercles near mandibles

(293) A. shehah Mohamedsaid, 1999-clypeus excavated, with a pair of spines in front of eyes and a pair of tubercles near mandibles

(294) Bacteriaspis pygmaeus Laboissiere, 1924-pronotum bulged in the middle of posterior margin; elytra with a pair of tubercles at base

(295) B. scutellata (Baly, 1878)_pronotum bulged in the middle of posterior margin; elytra with a pair of small tubercles at base

(296) Bangprella fulva Kimoto, 1989-antennae 7th enlarged, with small projection externally

(297) Bonesia missis Laboissiere, 1926-antennae 4th-8th serrate

(298) B. serricornis (Thomson, 1858)-antennae 4th-8th serrate

(299) Buckibrotica cinctipennis (Baly, 1886)—antennae 7th and 9th dilated, excavated

(300) Candezea atomaria (Fairmaire, 1875) —elytra with a heart-shaped postscutellar protrusion

(301) C. biocostata (Weise, 1907)—elytra with one pair of short postscutellar protrusions with ridges and one pair of long lateral protrusions with ridges, from humeri to apical third

(302) C. costatipennis Laboissiere, 1931-elytra with a heart-shaped postscutellar protrusion and a pair of lateral protrusions with ridges, from humeri to apical third

(303) C. flaveola (Gerstaecker, 1855)_elytra with a heartshaped postscutellar protrusion

(304) C. franzkrappi Wagner and Kutrscheid, 2005-elytra with a deep crater-like postscutellar depression

(305) C. haematura (Fairmaire, 1891) —elytra with a heartshaped postscutellar protrusion

(306) C. irregularis (Ritsema, 1893) —elytra with a deep oval shaped postscutellar depression

(307) C. occipitalis (Reiche, 1847)—elytra with a heartshaped postscutellar protrusion

(308) Cannonia confusa Silfverberg, 1971-pronotum bulged in the middle, the posterior margin with a tongue-shaped process, overhang scutellum; elytra with a pair of large tubercles at base

(309) C. meridionalis (Weise, 1901)_pronotum bulged in the middle and a tongue-shaped process on posterior margin overhang scutellum; elytra with a pair of large tubercles at base

(310) C. occidentalis (Weise, 1901)—pronotum with a short, concave tongue-shaped process on posterior margin overhang scutellum.

(311) C. petersii (Bertoloni, 1868)_pronotum with a short tongue-shaped process on posterior margin overhang scutellum

(312) Cerophysa andrewesi Jacoby, 1904-antennae 8th enlarged

(313) C. aseanica Mohamedsaid, 2001-antennae 8th enlarged

(314) C. biplagiata Duvivier, 1885-antennae 8th enlarged

(315) C. borneensis Jacoby, 1895-antennae 3rd and 4th enlarged

(316) C. chujoi (Kimoto, 1966)_antennae 3rd slightly curved, 4th-8th strongly curved; metatibiae with a curved process at apex

(317) C. coomani Laboissiere, 1930-antennae 8th enlarged

(318) C. cyanea (Kimoto, 1977)-antennae 4th, 5th, and 6th enlarged

(319) C. cyanipennis (Kollar and Redtenbacher, 1848)antennae 4 th, 5th, and 6th enlarged, deeply excavated

(320) C. darjeelingensis Takizawa and Basu, 1987antennae 8th enlarged

(321) C. dwiwarna Mohamedsaid, 2003 - antennae 6th and 7th enlarged

(322) C. erberi Beenen, 2005-antennae 3rd and 4th enlarged, excavated

(323) C. fascialis Jacoby, 1895-antennae 4th angularly emarginate

(324) C. flava Baly, 1886-antennae 8th enlarged

(325) C. fulvicollis Jacoby, 1892-antennae 8th greatly enlarged, deeply excavated

(326) C. gestroi Jacoby, 1896-antennae 8th enlarged

(327) C. javanensis Mohamedsaid, 1996-antennae 8th enlarged

(328) C. laosensis (Kimoto, 1989) —antennae 3rd, 4th, and 5 th enlarged

(329) C. mandarensis Jacoby, 1904-antennae 8th enlarged

(330) C. metallica Laboissiere, 1930-antennae 5th, 6th, and 7 th enlarged, 8th extremely long, longitudinally excavated

(331) C. monstrosa Jacoby, 1892 — antennae 5th enlarged, with distal edge, 6th broadly enlarged, 7th enlarged, 8th enlarged, extremely long, longitudinally excavated

(332) C. nigricollis Jacoby, 1896-antennae 6th and 7th enlarged, excavated

(333) C. nigricornis Jacoby, 1896-antennae 8th enlarged 
(334) C. nigripennis (Kimoto, 1966)—metatibiae with a curved process at apex

(335) C. nodicornis (Wiedemann, 1823) —antennae 6th and 7 th enlarged

(336) C. oculata Mohamedsaid, 2003-antennae 6th and 7 th enlarged; eyes large

(337) C. pulchella Laboissiere, 1930-antennae 8th enlarged

(338) C. purpurea Mohamedsaid, 2001-antennae 3rd10th covered with long hairs

(339) C. sitihasmah Mohamedsaid, 2003-antennae 8th enlarged

(340) C. splendens Duvivier, 1885-antennae 8th enlarged, excavated

(341) C. sumatrensis Jacoby, 1884-antennae 6th and 7th enlarged

(342) C. taiwana (Chujo, 1935)—antennae extremely long, 4 th slightly curved

(343) C. tibialis Jacoby, 1884-antennae 3rd-10th thickened, curved

(344) C. viridipennis Jacoby, 1884-antennae 8th enlarged

(345) C. vitiensis Bryant, 1941-antennae 9th enlarged, excavated

(346) C. wallacei Baly, 1877-antennae 6th and 7th enlarged

(347) C. warisan Mohamedsaid, 2003-antennae 8th enlarged

(348) C. zhenzhuristi Oglobin, 1936-antennae 3rd-7th enlarged

(349) Cerophysella alaf Mohamedsaid, 2001-antennae 3rd-6th thickened

(350) C. basalis (Baly, 1874) —elytra with elongate postscutellar depression

(351) C. plagiata Laboissiere, 1930-antennae 3rd-11th covered with long hairs

(352) C. viridipennis (Allard, 1889) — pronotum with a pair of tubercles before transverse depression; elytra with around postscutellar depression

(353) Cerotoma atrofasciata Jacoby, 1879-clypeus deeply excavated, without tubercle; antennae 3rd incised at apex, 4th triangular shaped

(354) C. dilatipes Jacoby, 1888-clypeus depressed; front tibiae dilated at apex

(355) C. ruficornis (Olivier, 1791)—clypeus deeply excavated, with a very prominent median tubercle; antennae 3 rd dilated, incised at apex, 4 th triangular shaped

(356) C. salvini Baly, 1866-clypeus excavated, with a prominent median tubercle; antennae 3rd dilated, incised at apex, 4th triangular shaped

(357) C. trifurcata (Forster, 1771)—clypeus excavated
(358) Chapuisia dilaticornis (Jacoby, 1906) — eyes large; antennae 9 th, 10th, and 11th dilated

(359) C. foveolata (Laboissiere, 1921) — eyes large; antennae 3rd-7th dilated

(360) C. fulva Bryant, 1952-eyes large; antennae 3rd-7th dilated

(361) C. kamerunensis (Laboissiere, 1912)—eyes large; antennae $3 \mathrm{rd}-7$ th dilated

(362) C. maculata (Weise, 1909) — eyes large; antennae 3rd7 th dilated

(363) C. mozambica (Laboissiere, 1931) —antennae 3rd7 th dilated

(364) C. natalensis (Jacoby, 1899) - antennae 3rd-7th dilated

(365) C. nigritarsis (Laboissiere, 1920) —antennae 3rd-7th dilated

(366) C. piceipes (Jacoby, 1899) —eyes large

(367) C. suahelorum (Weise, 1912)-eyes large; antennae $3 \mathrm{rd}-7$ th dilated

(368) C. subconnectens (Jacoby, 1906) —eyes large; antennae 3 rd-7th dilated

(369) Chthoneis boliviensis Bowditch, 1925-antennae 4th7th dilated

(370) C. dilaticornis Jacoby, 1888-antennae 4th-7th curved

(371) C. rosenbergi Bowditch, 1925-antennae 3rd-7th dilated; vertex extremely bulged; clypeus flattened

(372) C. rufulum Bowditch, 1925-eyes large; antennae 3rd-7th dilated

(373) C. stuarti Bowdicth, 1925-antennae 4th, 5th, and 6th dilated

(374) Clitena limbata Baly, 1864-antennae 4th-11th flattened

(375) C. sinensis (Fairmaire, 1888)—antennae 8th enlarged

(376) C. rubricollis (Hope, 1831) - antennae 9th, 10th, and 11 th greatly thickened

(377) Cneoranidea coryli Chen and Jiang, 1984-maxillary palpi with penultimate segment swollen; abdomen 1 st strongly produced covering sternites $2 \mathrm{nd}$, $3 \mathrm{rd}$ and 4 th

(378) C. flammea Yang, 1991-maxillary palpi with penultimate segment swollen

(379) C. hirta Yang, 1991-maxillary palpi with penultimate segment swollen; metasternum densely covered with long hairs

(380) C. signatipes Chen, 1942-maxillary palpi with penultimate segment swollen

(381) C. sinica Yang, 1991-maxillary palpi with penultimate segment swollen

(382) Coeligetes borneensis Mohamedsaid, 1994metatrochanter with a long spine 
(383) C. submetallica Jacoby, 1884-abdomen 4th deeply excavated, with a pair of spines

(384) C. wilcoxi Mohamedsaid, 1994-abdomen 4th deeply excavated, with a pair of spines

(385) Coelomera janthinipennis Bowditch, 1923-vertex very large; maxillary palpi swollen

(386) Coraia maculicollis Clark, 1865-antennae thickened; mesotibiae with a thick apical spur, hooked at tip

(387) C. subcyanescens (Schaeffer, 1906)_antennae thickened; mesotibiae with a thick apical spur, hooked at tip

(388) Cornubrotica dilaticornis (Baly, 1879) —antennae 8th and 9th dilated, excavated; mesofemora and mesotibiae enlarged, emarginate

(389) C. iuba Moura, 2005-antennae 8th and 9th dilated, excavated; protibiae emarginate

(390) Cyclotrypema furcata (Olivier, 1808)_labrum with a median hole; protibiae enlarged

(391) Deinocladus cartwrighti Blake, 1966-antennae 2nd and 3 rd compressed, 9 th and 10th enlarged; mesotibiae notched

(392) D. fascicollis Blake, 1966-antennae 5th-8th enlarged, 9th dilated; mesotibiae notched

(393) D. pectinicornis (Baly, 1890) - antennae 2nd and 3rd compressed, 5th-8th thickened; mesotibiae notched

(394) Dercetina viridipennis (Duvivier, 1887)—antennae 7th enlarged and curved

(395) Diabrotica alboplagiata Jacoby, 1882-antennae 4th8th thickened

(396) D. beniensis Kryson and Smith, 1987-antennae 4th, 5 th, and 6th thickened; eyes large

(397) D. carolae Kryson and Smith, 1987-antennae 4th8th thickened

(398) D. distincta Jacoby, 1882-maxillary palpi swollen; antennae 4 th-8th thickened; eyes large

(399) D. funerea Bowditch, 1911-antennae 4th-8th thickened

(400) D. fusculus Bowditch, 1911—antennae 4th-8th thickened

(401) D. hahneli Bowditch, 1892-antennae 4th-8th thickened

(402) D. klagii Bowditch, 1911-antennae 4th-8th thickened; eyes large

(403) D. linsleyi Kryson and Smith, 1987-antennae 4th8th thickened

(404) D. longicornis Say, 1824-antennae 4th-8th thickened

(405) D. luderwaldti Bowditch, 1911-antennae 4th-8th thickened; eyes large

(406) D. minuta Jacoby, 1878-antennae 4th-8th thickened
(407) D. nigrolineata Jacoby, 1878-antennae 4th-8th thickened; maxillary palpi swollen; eyes large

(408) D. pachitensis Bowditch, 1911-antennae 4th-8th thickened; eyes large

(409) D. peckii Bowditch, 1911—antennae 4th-8th thickened; maxillary palpi swollen; eyes large

(410) D. prolongata Jacoby, 1882-antennae 4th-8th thickened; eyes large

(411) D. rendalli Bowditch, 1911-antennae 4th-8th thickened; maxillary palpi swollen; eyes large

(412) D. rosenbergi Bowditch, 1911-antennae 4th-8th thickened; eyes large

(413) D. unistriata Jacoby, 1887-antennae 4th-8th thickened; maxillary palpi swollen; eyes large

(414) D. venezuelensis Jacoby, 1882-antennae 4th-8th thickened; eyes large

(415) D. viridula Fabricius, 1801—antennae 4th-8th thickened

(416) Diacantha abdominalis (Jacoby, 1891) —elytra with a pair of tubercles at apex

(417) D. affinis Weise, 1901-elytra with a pair of small tubercles at apex

(418) D. albidicornis Weise, 1901-elytra with a pair of small tubercles at apex

(419) D. apicata Weise, 1912-elytra with a pair of tubercles at apex

(420) D. beniensis (Laboissiere, 1924) —elytra with a pair of sharp-pointed tubercles at apex

(421) D. bidentata (Fabricius, 1781) —elytra with a pair of small tubercles at apex

(422) D. bifasciata (Laboissiere, 1924)—elytra with a pair of tubercles at apex

(423) D. bifida (Laboissiere, 1924) —elytra with a pair of small tubercles at apex

(424) D. bifossulata (Laboissiere, 1931)—elytra with a pair of tubercles at apex

(425) D. bifrons (Laboissiere, 1924) - elytra with a pair of large rounded tubercles at apex

(426) D. bifurcata (Laboissiere, 1924) —elytra with a pair of small tubercles at apex

(427) D. bisbipunctata Weise, 1903-elytra with a pair of small tubercles at apex

(428) D. bituberculata (Fabricius, 1781)—elytra with a pair of semicircular ridges at apex

(429) D. brevis (Laboissiere, 1940)—elytra with a pair of tubercles at apex

(430) D. burgeoni (Laboissiere, 1940) —elytra with a pair of tubercles at apex

(431) D. carinata (Laboissiere, 1924) —elytra with a pair of small tubercles at apex 
(432) D. caudata Weise, 1903-elytra with a pair of tubercles at apex

(433) D. caviventris (Laboissiere, 1940)—elytra with a pair of tubercles at apex

(434) D. cincta (Laboissiere, 1924) - elytra with a pair of semicircular ridges on apical half

(435) D. clavaeuri Weise, 1903-elytra with a pair of sharppointed tubercles at apex

(436) D. collaris Weise, 1901—elytra with a pair of tubercles at apex

(437) D. colmanti (Laboissiere, 1924)—elytra with a pair of small tubercles at apex

(438) D. colorata Chapuis, 1879-elytra with a pair of tubercles at apex

(439) D. complexa (Laboissiere, 1924)—elytra with a pair of tubercles at apex

(440) D. conradti Jacoby, 1903-elytra with a pair of tubercles at apex

(441) D. cupripennis (Laboissiere, 1924) —elytra with a pair of large bifurcate tubercles at apex

(442) D. deusseni Karsch, 1881-elytra with a pair of small tubercles at apex

(443) D. diffusa Weise, 1901-elytra with a pair of sharppointed tubercles at apex

(444) D. dimidiata (Laboissiere, 1924)_elytra with a pair of large kidney-shaped tubercles on apical half

(445) D. dubia (Laboissiere, 1924)—elytra with a pair of small tubercles at apex

(446) D. duplicata Gerstaecker, 1871—elytra with a pair of tubercles at apex

(447) D. elegans (Laboissiere, 1924)—elytra with a pair of tubercles at apex

(448) D. enodis Weise, 1903_elytra with a pair of large oval shaped tubercles at apex

(449) D. equatorialis (Laboissiere, 1924)_elytra with a pair of small tubercles at apex

(450) D. feai (Laboissiere, 1924) —elytra with a pair of large tubercles at apex

(451) D. flavipes Karsch, 1881-elytra with a pair of tubercles at apex

(452) D. flavodorsata (Fairmaire, 1893) —elytra with a pair of small tubercles at apex

(453) D. flavonigra (Thomson, 1858)—elytra with a pair of tubercles at apex

(454) D. fulva (Laboissiere, 1924)_elytra with a pair of large oval shaped tubercles at apex

(455) D. ghesquierei (Laboissiere, 1940)—elytra with a pair of tubercles at apex

(456) D. humilis Weise, 1903-elytra with a pair of large oval shaped tubercles on apical half
(457) D. hybrida (Laboissiere, 1924) —elytra with a pair of small tubercles at apex

(458) D. hypomelaena (Thomson, 1858)_elytra with two pairs of small tubercles at apex

(459) D. imitans (Laboissiere, 1924) —elytra with two pairs of sharp-pointed tubercles at apex

(460) D. incerta Weise, 1901-elytra with a pair of tubercles at apex

(461) D. insignipennis Thomson, 1858-elytra with a pair of tubercles at apex

(462) D. jacobyi Weise, 1901-elytra with a pair of small tubercles at apex

(463) D. kolbei Weise, 1903-elytra with a pair of tubercles at apex

(464) D. kraatzi (Jacoby, 1895)—elytra with a pair of tubercles at apex

(465) D. lacordairei Chapuis, 1879-elytra with a pair of tubercles at apex

(466) D. longula Weise, 1903-elytra with a pair of tubercles at apex

(467) D. marshalli (Laboissiere, 1924) —elytra with a pair of small tubercles at apex

(468) D. mimula Weise, 1903 — elytra with pair of tubercles at apex

(469) D. modesta Weise, 1903-elytra with a pair of tubercles at apex

(470) D. nigricornis Weise, 1901-elytra with a pair of pointed tubercles at apex

(471) D. nigrococcinea (Laboissiere, 1924)—elytra with a pair of tubercles at apex

(472) D. overlaeti (Laboissiere, 1940)_elytra with a pair of tubercles at apex

(473) D. palladina (Bechyne, 1964) - elytra with a pair of tubercles at apex

(474) D. pallidula (Laboissiere, 1924) —elytra with a pair of large, sharp-pointed tubercles and a pair of small tubercles at apex

(475) D. pallipes Weise, 1901-elytra with a pair of small tubercles at apex

(476) D. parvula Weise, 1903_elytra with a pair of tubercles at apex

(477) D. patrizii (Laboissiere, 1937) —elytra with a pair of small tubercles at apex

(478) D. pauli Weise, 1903-elytra with a pair of small tubercles at apex

(479) D. pectoralis (Fairmaire, 1893)—elytra with a pair of tubercles at apex

(480) D. preussi Weise, 1903-elytra with a pair of tubercles at apex

(481) D. punctatissima (Jacoby, 1891) —elytra with a pair of tubercles at apex 
(482) D. regularis Weise, 1907-elytra with a pair of tubercles at apex

(483) D. seminigra (Allard, 1888)-elytra with a pair of pointed tubercles at apex

(484) D. senegalensis (Laboissiere, 1924)_elytra with a pair of small tubercles at apex

(485) D. silvana (Jacoby, 1906) —elytra with a pair of large, sharp-pointed tubercles at apex

(486) D. similis (Laboissiere, 1924)_elytra with a pair of small tubercles at apex

(487) D. sinuosa Weise, 1903-elytra with a pair of small tubercles at apex

(488) D. sternalis (Laboissiere, 1924) - elytra with a pair of small tubercles at apex

(489) D. straeleni (Laboissiere, 1939) —elytra with a pair of small tubercles at apex

(490) D. stuhlmanni Weise, 1903-elytra with a pair of tubercles at apex

(491) D. tsaratananae (Bechyne, 1964) —elytra with a pair of tubercles at apex

(492) D. uelensis (Laboissiere, 1924)_elytra with a pair of oblique ridges at apex

(493) D. unifasciata (Olivier, 1808)_elytra with a pair of large, sharp-pointed tubercles at apex

(494) D. varians Weise, 1901-elytra with a pair of large, sharp-pointed tubercles at apex

(495) D. verticalis (Faimare, 1893) —elytra with a pair of small tubercles at apex

(496) D. vicina (Laboissiere, 1924) —elytra with a pair of small tubercles at apex

(497) Dimalianella rugicollis (Laboissiere, 1929)_antennae very long, covered with long hairs

(498) D. testacea (Laboissiere, 1926)—antennae very long, covered with long hairs

(499) Dircemella marginata (Baly, 1879)_antennae 8th greatly enlarged, obliquely truncate at apex

(500) Doryscus scapus Mohamedsaid, 1999-antennae 1st enlarged, excavated

(501) Dreeus distinctus Shute, 1983-antennae 9th and 11th enlarged; mesotibiae curved

(502) Duvivieria africana (Duvivier, 1892)—metatibiae with a long process at apex

(503) D. apicitarsis (Weise, 1903)—antennae 7th elongate, strongly curved, crescent shaped

(504) Eccoptopsis argentinensis Blake, 1966-clypeus moderately excavated, with two short spines on each side; antennae $3 \mathrm{rd}$ and 4 th enlarged, excavated

(505) E. boliviensis Blake, 1966-clypeus excavated with spines; antennae 3rdand 4th enlarged, excavated
(506) E. cavifrons Blake, 1966-clypeus excavated, with a small spine in middle; antennae 3 rd and 4 th enlarged, excavated

(507) E. clara Blake, 1966-clypeus excavated, with spines; antennae 3rd and 4th enlarged, excavated

(508) E. costaricensis Blake, 1966-clypeus deeply excavated, with a pair of long, curved spines at sides; antennae 3rd and 4th enlarged, excavated

(509) E. cyanocositiesa Blake, 1966-clypeus moderately excavated; antennae 3rd and 4th enlarged, excavated

(510) E. denticornis (Jacoby, 1887) clypeus excavated with spines; antennae $3 \mathrm{rd}$ and 4 th enlarged, excavated

(511) E. laticollis Blake, 1966-clypeus deeply excavated, with a pair of long curved spines at sides; antennae 3rd and 4th enlarged and excavated

(512) E. mexicana Blake, 1966-clypeus excavated, with a long thick spine in the middle; antennae 3rd longitudinally depressed at sides, 4th curved, excavated

(513) E. piceofasciata Blake, 1966-clypeus excavated, with a short spine in the middle; antennae 3rd long, excavated, 4th enlarged, slightly excavated; front tibiae enlarged

(514) E. quadriniaculata Blake, 1966-clypeus deeply excavated, with fringe of hairs overhanging the cavity on both sides; antennae 3rd and 4th enlarged

(515) E. quadrimaculata Blake, 1966-clypeus excavated with spines; antennae 3rd and 4 th enlarged

(516) Ectmesopus crassicornis Blake, 1940-antennae 8th10th enlarged

(517) E. darlington Blake, 1940-antennae 5th-9th serrate, 10th greatly enlarged

(518) E. pallidus Blake, 1940-antennae 10th greatly enlarged, oblong, excavated

(519) Eleona uniformis Bechyne, 1957-antennae covered with long hairs, 1st enlarged; front tibiae strongly dilated at apex

(520) Elyces quadrimaculatus Jacoby, 1888-elytral humeri extremely bulged

(521) Ephaenidea indochinensis Medvedev, 2004mesotibiae with a long projection at apex

(522) Erynephala brighti Blake, 1970_tarsal claws bifid

(523) E. glabra Blake, 1936-tarsal claws bifid

(524) E. puncticollis (Say, 1824)—tarsal claws bifid

(525) E. morosa (Leconte, 1857)_tarsal claws bifid

(526) E. maritime (Leconte, 1865)—tarsal claws bifid

(527) Erythrobapta benigseni Weise, 1902-elytra with shallow postscutellar cavities

(528) Euliroetis lameyi (Laboissiere, 1929)_abdomen 4th and 5 th excavated in the middle

(529) E. melanocephala (Bowditch, 1925)_abdomen 2nd with a pair of appendages, 4th deeply excavated 
(530) E. nigronotum Gressitt and Kimoto, 1963-abdomen 1 st with a pair of short appendages, 2 nd and 3 rd each with a pair of very long appendages, 4 th excavated

(531) E. ornata (Baly, 1874)_abdomen 1st and 2nd each with a pair of appendages

(532) E. suturalis (Laboissiere, 1929) —abdomen 2nd with a pair of very broad appendages, 4 th deeply excavated

(533) Eusattodera intermixtus (Fall, 1910)—clypeus excavated

(534) Exosoma clypeata (Jacoby, 1895)—clypeus excavated

(535) E. deformicornis (Quedenfeldt, 1888)—antennae 3rd-11th thickened, 8th enlarged, oblong

(536) E. discoidale (Jacoby, 1895)—antennae 3rd-8th thickened

(537) E. tripunctata (Jacoby, 18 ) - elytra with cavities at sides

(538) Fleutiauxia armata (Baly, 1874)_clypeus transversely excavated, with a projection on posterior ridge

(539) F. bicavifrons Gressitt and Kimoto, 1963-clypeus with a large deep cavity on each side of the middle, with a short projection on anterior and posterior of the cavity

(540) F. cyanipennis Laboissiere, 1933_clypeus with transversely deeply excavated, with a short projection in the middle

(541) F. multifrons Gressitt and Kimoto, 1963-clypeus transversely excavated, with a tall projection, and an anterior projection on posterior ridge

(542) F. septentrionalis (Weise, 1922)_clypeus transversely excavated, with a backward projection on posterior ridge

(543) F. violaceipennis Kimoto, 1989-clypeus transversely excavated, with a long projection

(544) Geinula antennata Chen, 1961-antennae 4th enlarged, globose

(545) Gynandrobrotica imitans (Jacoby, 1879)—clypeus flattened as single piece; maxillary palpi swollen

(546) G. nigrofasciata (Jacoby, 1887)_clypeus flattened as a single piece; maxillary palpi swollen

(547) G. parambaensis (Bowditch, 1912)—clypeus broadly, smoothly, deeply excavated, sides with rows of long hairs; maxillary palpi swollen

(548) Halysacantha weisei (Jacoby, 1899)-antennae 3rd broadly dilated, deeply excavated; scutellum excavated, with sides raised into high ridges; elytra with a pair of tubercles at base

(549) Haplosomoides abdominalis Kimoto, 1984-antennae 3rd-10th dilated; middle tibiae curved

(550) H. annamita Allard, 1888-eyes large

(551) H. antennalis Mevdvedev, 2000 — antennae 4th-7th covered with long hairs
(552) H. appendiculata Laboissiere, 1930-eyes large; abdomen 1st with a long appendage

(553) H. biclavata Jiang, 1988-abdomen 2nd with a pair of short and 3rd a pair of long appendages

(554) H. brushei Jang, 1988-abdomen 1st with a brushlike appendage

(555) H. changi Lee, Bezděk and Staines, 2011-abdomen 1st with a long appendage, the apical third lateral margins with rows of long hairs

(556) H. chengi Lee, Bezděk and Staines, 2011-abdomen 1 st with a long appendage and its apical third densely covered with short setae

(557) H. chinmatra Maulik, 1936-abdomen 1st with a long appendage; antennae thickened towards apex

(558) H. costata Baly, 1878-abdomen 1st with a long appendage

(559) H. curvipes Medvedev, 2000-hind tibiae curved

(560) H. egena Weise, 1922-abdomen 1st with a slender appendage

(561) H. flava Laboissiere, 1930-eyes large

(562) H. hainana Jang, 1988-abdomen 1st with a brush like appendage

(563) H. himalayana Medvedev, 2002-antennae 7th11th thickened; abdomen 5 th with a short pointed appendage

(564) H. laticornis Laboissiere, 1930-antennae 7th-11th dilated; abdomen 1st with a long appendage

(565) H. nigricollis Jang, 1988-abdomen 3rd with a pair of appendages

(566) H. ryukyuensis Lee, Bezděk and Staines, 2011abdomen 1st with a long appendage, the apical third lateral margins with rows of long hairs

(567) Hemygascelis longicollis Jacoby, 1896-abdomen 1st tuberculate, 2nd, 3rd, and 4th with long erect hairs, 5 th elongate, densely covered with hairs along the middle

(568) Hoplasoma apicale Jacoby, 1884-abdomen 1st with a pair of short appendages, 2nd with a long pair of appendages

(569) H. bosi Bezděk, 2008-abdomen 2nd with a pair of narrow and very short appendages

(570) H. celebense Jacoby, 1886-abdomen 2nd with a pair of appendages

(571) H. costatipennis Jacoby, 1896-abdomen 2nd with tubercles

(572) H. dilaticornis Jacoby, 1900-antennae 8th, 9th, and 10th dilated; hind tibiae curved

(573) H. luzonica Medvedev, 2002-abdomen 2nd with a pair of appendages, widely separated

(574) H. mindanensis Medvedev, 2002-abdomen 2nd with a pair of appendages 
(575) H. minor Gressitt and Kimoto, 1963-abdomen 2nd with a pair of appendages

(576) H. nilgiriensis Jacoby, 1904-abdomen 2nd with a pair of short, flat appendages

(577) H. paradoxum Medvedev, 2007-abdomen 2nd with a pair of appendages

(578) H. philippinensis Jacoby, 1894-abdomen 2nd with a pair of short pointed appendages

(579) H. rostripenne Allard, 1888-abdomen 2nd with a pair of large appendages

(580) H. sulawesianum Medvedev, 2007-abdomen 2nd with a pair of large appendages; hind tibiae dilated at apex

(581) H. unicolor (Illiger, 1800)_abdomen 2nd with a pair of appendages

(582) Hoplosaenidea abdominalis (Jacoby, 1884) - hind tibiae curved, dilated, and compressed at the middle

(583) H. aerosa (Laboissiere, 1933)—clypeus deeply excavated, with a prominent tubercle in the middle; antennae 3 rd and 4 th enlarged

(584) H. apicipennis Baly, 1888-clypeus broadened, strongly raised, with median longitudinal groove

(585) H. capitata (Jacoby, 1886) —clypeus excavated, with a pair of pointed projections

(586) H. cavifrons (Duvivier, 1885)—clypeus very deeply excavated, with a pair of flap-like projections

(587) H. citrina (Jacoby, 1894) — protibiae dilated at apex

(588) H. coomani (Laboissiere, 1933)_clypeus shallowly excavated

(589) H. cornuta (Laboissiere, 1933)—clypeus deeply, broadly excavated, with a tubercle

(590) H. elegans Kimoto, 1989-clypeus deeply, broadly excavated

(591) H. facialis (Baly, 1888)—clypeus excavated, with a triangular, flat tubercle in basal half

(592) H. fragilis Gressitt and Kimoto, 1963-clypeus very deeply excavated

(593) H. laosensis Kimoto, 1989—clypeus deeply, broadly excavated

(594) H. merah Mohamedsaid, 2001—antennae 4th dilated, compressed

(595) H. monstrosa (Jacoby, 1896)—clypeus deeply excavated, with a short projection on frons

(596) H. nigripennis (Laboissiere, 1940)—clypeus excavated

(597) H. nigrolimbata (Jacoby, 1899)—metatibiae dilated and curved at the middle

(598) H. nitida Gressitt and Kimoto, 1963-clypeus moderately excavated

(599) H. ocellata (Baly, 1888)—clypeus deeply excavated, with 2 pairs of tubercles
(600) H. porrecta (Baly, 1865)—clypeus excavated, with a projection; antennae 1st dilated, with a pointed distal edge

(601) H. pulchella (Laboissiere, 1933)_clypeus shallowly excavated

(602) H. sarah Mohamedsaid, 2009-clypeus deeply excavated, with a projection in middle; antennae 1st dilated, with a pointed distal edge

(603) H. semilimbata (Jacoby, 1894)—clypeus deeply excavated, with a pair of pointed spines on frons

(604) H. semperi (Jacoby, 1894)—clypeus deeply excavated, with a horn-like projection on frons

(605) H. subcostata (Jacoby, 1884) - antennae 3rd and 4th compressed, dilated

(606) H. singaporensis Mohamedsaid, 2002-clypeus excavated; antennae 1st dilated, with a pointed distal edge

(607) H. takizawai Mohamedsaid, 2000-clypeus deeply excavated, with a projection; antennae 1st dilated, with a pointed distal edge

(608) H. touzalini Laboissiere, 1933-metatibiae with a long curved process at apex

(609) H. tripunctata (Jacoby, 1894)—clypeus depressed; eyes large

(610) H. variabilis (Jacoby, 1894)—clypeus with a narrow, elongate cavity

(611) H. violacea (Jacoby, 1892)—clypeus deeply excavated, with a projection in the middle

(612) Huillania bifasciata Laboissiere, 1931-antennae 3rd-8th thickened, reniform

(613) H. foramina Laboissiere, 1921-antennae 3rd-8th thickened, curved

(614) H. gibbicollis Laboissiere, 1931-antennae 3rd-8th thickened

(615) Hylaspoides magnifica Duvivier, 1892-antennae 3rd enlarged, triangularly dilated

(616) Hymnesia tranquebarica (Fabricius, 1798)-antennae 8 th enlarged, concave on ventral surface

(617) Hyphaenia aenea Laboissiere, 1936-antennae 3rd11 th densely covered with long hairs

(618) H. africana Laboissiere, 1921-antennae 3rd-11th densely covered with long hairs

(619) H. antennalis Kimoto, 1989-antennae 3rd-5th covered with long hairs

(620) H. apicicornis Jacoby, 1896-antennae 3rd-11th covered with long hairs

(621) H. azlani Mohamedsaid, 1998-antennae 3rd-8th covered with long hairs

(622) H. bicolor Medvedev, 2001-antennae 3rd-5th covered with long hairs; clypeus excavated, with triangular tooth at anterior margin 
(623) H. clypealis Medvedev, 2001-antennae 3rd-11th covered with long hairs; clypeus flat with long hairs

(624) H. cyanescens Laboissiere, 1936-antennae 3rd-11th covered with long hairs

(625) H. discoidalis Jacoby, 1886-antennae 3rd-8th covered with long hairs

(626) H. frontalis Kimoto, 1989-clypeus excavated, with a projection at posterior margin

(627) H. fulva Kimoto, 1989-antennae 8th and 9th curved

(628) H. indica (Jacoby, 1903)—antennae 3rd-8th covered with erect hairs

(629) H. keralensis Medvedev, 2001-antennae 3rd-6th with covered short erect hairs

(630) H. kimotoi Medvedev, 2001-clypeus deeply excavated

(631) H. mandibularis Medvedev, 2001-antennae 3rd-8th with long hairs

(632) H. nigricornis Kimoto, 1989-clypeus broadly excavated

(633) H. nigrilabris Medvedev, 2001-antennae 4th curved

(634) H. nitidissima Medvedev, 2001-antennae 3rd-11th covered with long hairs

(635) H. obscuripennis Jacoby, 1896-antennae 3rd-8th covered with long hairs

(636) H. oculata Mohamedsaid, 1999_antennae 3rd-8th covered with long hairs; eyes very large; maxillary palpi swollen

(637) H. pallida Medvedev, 2001—antennae 3rd and 4th covered with long hairs

(638) H. pilicornis (Motschulsky, 1858)—antennae 3rd-8th with long hairs

(639) H. rahmani Mohamedsaid, 1999-antennae extremely long, 3rd-8th covered with long hairs and 3rd-11th longitudinally ridged; frontal tubercles prominent, very large; eyes large

(640) H. rubra Medvedev, 2001-antennae 3rd-8th covered with long hairs

(641) H. submetallica Jacoby, 1892 - antennae 3rd-8th covered with long hairs

(642) H. tristis Medvedev, 2001-antennae 9th and 10th dilated, excavated; clypeus excavated

(643) H. volkovitshi Lopatin, 2009-antennae 3rd-11th covered with long hairs; clypeus deeply excavated

(644) Hystiopsis beniensis Blake, 1966-clypeus excavated; maxillary palpi swollen

(645) H. marginalis (Fabricius, 1801)_protibiae enlarged

(646) H. terminalis Blake, 1966-protibiae enlarged

(647) H. zonata Blake, 1966-protibiae thickened

(648) Inbioluperus costipennis Clark, 1993-abdomen 2nd with a short rectangular appendage
(649) Jacobya cavicollis (Fairmaire, 1880)—pronotum deeply, broadly, triangularly excavated, with a tubercle in the middle

(650) J. notabilis Weise, 1902-pronotum with basal half deeply excavated

(651) J. ochracea Weise, 1901-pronotum entirely, deeply excavated

(652) J. pilosa Weise, 1902-pronotum with basal half deeply excavated

(653) J. viridis Weise, 1904-pronotum with middle area deeply excavated

(654) Japonitata abdominalis Jiang, 1989-antennae 9th with a spine at apex, 10th enlarged, 11th larger, longer than 1st

(655) J. antennata Chen and Jiang, 1986-antennae 8th thickened, 9th minute, 10th dilated, 11th larger, longer than 1 st

(656) J. hongpingana Jiang, 1989-antennae 8th dilated, 9th dilated, shorter than 9th, 10th dilated, pointed at apex, 11th longer than the first segment

(657) Kanahiiphaga aeneipennis Laboissiere, 1937clypeus transversely excavated, with a projection

(658) K. carpenteri Laboissiere, 1937-clypeus transversely excavated, with a projection

(659) K. costipennis Laboissiere, 1936-clypeus transversely excavated, with a projection

(660) K. costulata Laboissiere, 1931-clypeus transversely excavated, with a projection

(661) K. frontalis Laboissiere, 1936-clypeus transversely excavated, with a projection

(662) K. orphana (Chapuis, 1879)—clypeus transversely excavated, with a projection

(663) K. similis Laboissiere, 1936-clypeus transversely excavated, with a projection

(664) Kinabalua antennata Mohamedsaid, 1997-antennae 7 th enlarged, excavated at apex, 8th enlarged, with a broad, short spine; metasternum with a process

(665) Kinabalua musaamani Mohamedsaid, 2010-antennae 7 th enlarged, excavated at apex, 8th enlarged, with a long, curved spine; metasternum with a process

(666) Kumbalia longicornis Mohamedsaid and Takizawa, 2007-antennae extremely long, beyond elytra

(667) Laetana histrio Baly, 1864-antennae with segments 3rd-7th dilated

(668) Laetiacantha amabilis (Laboissiere, 1940)—antennae 3rd-7th dilated; pronotum with a small, elliptical depression on each side of midline at posterior margin; elytra with a pair of tubercles at the base

(669) L. distincta (Gahan, 1893) — antennae 3rd-7th dilated towards apex; pronotum with small sharp elevations at posterior margin; elytra with a pair of blunt tubercles at base 
(670) L. elegans Laboissiere, 1923-antennae 3rd-7th dilated; pronotum with sharp elevation at posterior margin; elytra with a pair of blunt tubercles at the base

(671) L. freynei Silfverberg, 1975-antennae 3rd-7th dilated; pronotum with sharp elevation at posterior margin; elytra with a pair of tubercles at base

(672) L. maynei (Laboissiere, 1921)-antennae 3rd-7th dilated; elytra with a pair of pointed tubercles at the base

(673) L. ruficollis Laboissiere, 1921-antennae 3rd-7th dilated; pronotum strongly impressed with sharp elevation at posterior margin; elytra with a pair of blunt tubercles at the base

(674) L. simillima Silfverberg, 1975-antennae 3rd-7th dilated; pronotum with a semicircular projection in the middle at posterior margin; elytra with a pair of tubercles at the the base

(675) L. splendens Silfverberg, 1975-antennae 3rd-7th dilated; pronotum with semicircular projection in middle at posterior margin; elytra with a pair of tubercles at base

(676) L. subsudanica (Weise, 1907)-antenna 3rd-7th dilated; pronotum with a small depression on each side of midline at posterior margin; elytra with a pair of tubercles at the base

(677) L. verax Silfverberg, 1975-antennae 3rd-7th dilated; pronotum with sharp elevation at posterior margin; elytra with a pair of tubercles at base

(678) Lamprocopa antennata (Weise, 1903)—frons excavated, with a projection

(679) L. dalata (Erichson, 1843)—frons excavated, with a projection

(680) L. femoralis (Laboissiere, 1929)—frons excavated, with a projection

(681) L. kunowi (Weise, 1892)—frons excavated, with a projection

(682) L. nigripennis (Laboissiere, 1921)—frons excavated, with a projection

(683) L. occidentalis (Weise, 1895)—frons excavated, with a projection

(684) L. orientalis (Weise, 1903) — frons excavated, with a projection

(685) L. praecox (Klug, 1833)—frons excavated, with a projection

(686) L. rothschildi (Laboissiere, 1920)—frons excavated, with a projection

(687) L. seabrai (Gomez Alves, 1951)—frons excavated, with a projection

(688) Leptaulaca nigra Laboissiere, 1920-antennae with long erect hairs

(689) L. nigricornis Weise, 1902-antennae with long erect hairs
(690) L. pusila Weise, 1912 — antennae with long erect hairs

(691) L. undecimpunctata (Klugg, 1833)_antennae with long erect hairs

(692) L. venusta Laboissiere, 1930-antennae with long erect hairs; front tibiae curved

(693) Leptoxena eximia Baly, 1888-antennae 9th, 10 and 11 th compressed; hind femora incrassate; hind tibiae channelled, with a process at apex

(694) Lesnella fasciata Laboissiere, 1931-antennae 4th7 th thickened; elytra with elevated postscutellar area at suture

(695) Lilophaea brasiliensis (Jacoby, 1888)—metatibiae strongly curved

(696) Liroetiella antennata Mohamedsaid and Kimoto, 1998-antennae 3rd enlarged, subtriangular, 4th enlarged, oblong

(697) Liroetis leycestriae Jiang, 1988-abdomen 4th with a tubercle at the middle of posterior margin

(698) L. spinipes Oglobin, 1936-metatrochanters with a long spine

(699) L. prominensis Jang, 1988-eyes large

(700) L. violaceipennis Zhang, $\mathrm{Li}$, and Yang, 2008abdomen 4th with a triangular appendage at the middle

(701) Lomirana dimidiata Laboissiere, 1932-elytra with large oval shaped postscutellar cavities

(702) Luperodes angustofasciata Bowditch, 1923-maxillary palpi swollen; eyes large; metatibiae curved

(703) L. pygidialis Laboissiere, 1921-antennae 4th thickened

(704) L. rufus Harold, 1877-antennae 4th thickened

(705) Luperogala mirabilis Medvedev and Samoderzhenkov, 1989-abdomen 4th with a sword-like, curved appendage, 5 th with a pair of lateral appendages

(706) L. paradoxa Medvedev and Samoderzhenkov, 1989-abdomen 4th with a curved, stylet-shaped appendage, dilated at apex, 5th with a pair of lateral appendages

(707) Luperosoma atlanta (Bechyne, 1950)_antennae 9th, 10th, and 11th enlarged; mesotibiae notched

(708) L. bechynei (Blake, 1966)_antennae 9th, 10th, and 11th enlarged; mesotibiae notched

(709) L. latifrons (Blake, 1966)—antennae 9th, 10th, and 11th enlarged; mesotibiae notched

(710) L. nigricolle Blake, 1966-antennae 8th-11th thickened; mesotibieae notched

(711) L. parallelum (Horn, 1893)—antennae 11th swollen; mesotibiae notched on inner side

(712) L. parvalum (Jacoby, 1888)-antennae 9th-10th thickened; mesotibiae notched 
(713) L. schwarzi (Horn, 1896)_antennae 11th swollen; abdomen 1st with a prominent tubercle; mesotibiae notched on inner side

(714) L. subsulcatum (Horn, 1893)_antennae 11th swollen; mesotibiae notched on inner side

(715) L. vittatum Blake, 1966-antennae 5th-8th enlarged; protibiae enlarged, mesotibiae deeply notched

(716) Lygistus streptophallus Wilcox, 1965-profemora enlarged

(717) Macrima armata Baly, 1878-clypeus deeply excavated, with a pair of small projections

(718) M. aurantiaca (Laboissiere, 1936)—clypeus deeply excavated, with a broad projection

(719) M. bifida Yang, 1992—clypeus deeply excavated, with a pair of projection

(720) M. cornuta (Laboissiere, 1936)—clypeus deeply excavated, with a pair of acute projections

(721) M. ferrugina Jiang, 1990-clypeus deeply excavated, with three projections

(722) M. pallida (Laboissiere, 1936)_clypeus excavated, with a pair of broad and a pair of acute projections

(723) M. rubricata (Fairmaire, 1889)—clypeus excavated, with a long median projection, angulate apical ridge, and sinuate lateral ridges

(724) M. straminea (Oglobin, 1936)_clypeus excavated, with a simple median ridge, bifurcated apically, and long lateral ridges

(725) M. yunnanensis (Laboissiere, 1936)_clypeus excavated, with a pair of projections

(726) Mahutia rougemonti Silfverberg, 1980-antennae long, covered with long hairs; all femora incrassate

(727) Malacorhinus antennatus Jacoby, 1887-antennae $3 \mathrm{rd}, 4 \mathrm{th}, 5 \mathrm{th}$, and 6 th enlarged

(728) M. basalis Jacoby, 1887-antennae 1st enlarged; vertex excavated

(729) M. biplagiatus Jacoby, 1887-elytra with sides angulate, excavated bearing tubercles

(730) M. cobanensis Jacoby, 1887-elytra with sides strongly angulate, excavated bearing tubercles

(731) M. decempunctatus Jacoby, 1887-elytra with sides angulate, excavated bearing tubercles

(732) M. dilaticornis Jacoby, 1887-antennae 3rd greatly enlarged, 4th dilated, triangular shaped

(733) M. exclamations Jacoby, 1892-elytra with sides angulate, excavated bearing tubercles

(734) M. foveipennis (Jacoby, 1879)—elytra with sides angulate, excavated bearing tubercles; antennae 1st enlarged

(735) M. irregularis (Jacoby, 1887)—elytra with sides angulate, excavated bearing tubercles
(736) M. sericeus Jacoby, 1887-elytra with sides angulate, excavated bearing tubercles

(737) M. tricolor Jacoby, 1887-antennae 7th-10th strongly dilated, triangular shaped

(738) M. tilghmani Mignot, 1970-elytra with sides angulate, excavated bearing tubercles; antennae 1st enlarged

(739) Megalognatha abyssinica Jacoby, 1886 — antennae 7th enlarged

(740) M. alutaceipennis Laboissiere, 1937-antennae 6th, 7 th, and 8th enlarged

(741) M. apicalis Weise, 1904-antennae 6th, 7th, and 8th enlarged

(742) M. apicicornis Laboissiere, 1926-antennae 8th and 9th enlarged

(743) M. bequaerti Laboissiere, 1926-antennae 7th, 8th, and 9 th enlarged

(744) M. bipunctata Jacoby, 1883-antennae 7th, 8th, and 9th enlarged

(745) M. bodongi Weise, 1905-antennae 6th and 7th enlarged

(746) M. bryanti Laboissiere, 1927-antennae 6th, 7th, and 8 th enlarged

(747) M. burgeoni Laboissiere, 1940-antennae 7th enlarged

(748) M. camerounensis Laboissiere, 1927-antennae 7th enlarged

(749) M. carinata Laboissiere, 1921-antennae 7th enlarged

(750) M. chevalieri Laboissiere, 1921-antennae 7th enlarged

(751) M. cruciata Jacoby, 1883 - antennae 6th, 7th, and 8th enlarged

(752) M. cyanipennis Weise, 1902-antennae 6th, 7th, 8th, and 9th enlarged

(753) M. diluta Laboissiere, 1927 antennae 7th and 8th enlarged

(754) M. femoralis Laboissiere, 1940-antennae 6th, 7th, 8 th, and 9th enlarged

(755) M. granulicollis Jacoby, 1903-antennae 6th-9th enlarged

(756) M. grouvellei Weise, 1912-antennae 7th enlarged

(757) M. guttata Laboissiere, 1927-antennae 7th enlarged

(758) M. hamaticornis Laboissiere, 1927-antennae 5th11 th

(759) M. hirticollis Jacoby, 1903-antennae 7th enlarged

(760) M. imbecilla Weise, 1902 - antennae 7th enlarged

(761) M. imperialis Laboissiere, 1940-antennae 6th, 7th, and 8th enlarged 
(762) M. kapiriensis Laboissiere, 1926-antennae 7th enlarged

(763) M. lundana Laboissiere, 1939-antennae 7th and 8th enlarged

(764) M. maculicollis Laboissiere, 1927-antennae 7th enlarged

(765) M. marginata Laboissiere, 1927-antennae 7th enlarged

(766) M. marginicollis Bryant, 1958-antennae 6th and 7th enlarged

(767) M. maynei Laboissiere, 1927-antennae 7th enlarged

(768) M. melanaria Laboissiere, 1926-antennae 7th enlarged

(769) M. metallica Jacoby, 1886-antennae 7th enlarged

(770) M. montana Laboissiere, 1939-antennae 7th and 8th enlarged

(771) M. nigroaenea Laboissiere, 1926-antennae 6th, 7th, and 8th enlarged

(772) M. nigrocastanea Laboissiere, 1931-antennae 7th enlarged

(773) M. nigrofasciata Jacoby, 1903-antennae 7th and 8th enlarged

(774) M. nodicornis Laboissiere, 1927-antennae 5th enlarged

(775) M. nyassensis Laboissiere 1926-antennae 6th, 7th, and 8th enlarged

(776) M. pilicollis Laboissiere, 1940-antennae 6th and 7th enlarged

(777) M. pilosa Laboissiere, 1926-antennae 7th enlarged

(778) M. pimenteli Laboissiere, 1939-antennae 7th, 8th, and 9 th enlarged

(779) M. pubescens Laboissiere, 1926-antennae 7th enlarged

(780) M. reflecta Laboissiere, 1926-antennae 7th, 8th, and 9th enlarged

(781) M. rohani Laboissiere, 1921-antennae 7th enlarged

(782) M. rolleti Laboissiere, 1926-antennae 6th, 7th, and 8th enlarged

(783) M. ruandana Weise, 1913-antennae 6th, 7th, and 8th enlarged

(784) M. rugipennis Laboissiere, 1927-antennae 6th, 7th, and 8th enlarged

(785) M. scopularipes Laboissiere, 1927-antennae 6th, 7th, and 8th enlarged

(786) M. scopsorum Laboissiere, 1940-antennae 7th, 8th, and 9 th enlarged

(787) M. semicincta Laboissiere, 1940-antennae 7th enlarged

(788) M. simplex Weise, 1904-antennae 7th, 8th, and 9th enlarged
(789) M. subcylindrica Baly, 1878-antennae 7th, 8th, and 9th enlarged

(790) M. sudanica Laboissiere, 1926-antennae 7th enlarged

(791) M. unifasciata Jacoby, 1883-antennae 7th, 8th, and 9th enlarged

(792) M. usambarica Weise, 1904-antennae 6th, 7th, and 8th enlarged

(793) M. variicornis Weise, 1902-antennae 6th, 7th, and 8th enlarged

(794) M. ventricosa Baly, 1878-antennae 6th and 7th enlarged

(795) M. verticalis Laboissiere, 1939-antennae 7th enlarged

(796) M. vicina Laboissiere, 1926-antennae 6th, 7th, and 8th enlarged

(797) M. woodi Laboissiere, 1927-antennae 7th, 8th, 9th, and 10th enlarged

(798) Metacoryna fulvicollis Jacoby, 1888-antennae 8th extremely large, globose

(799) M. fulvipes Jacoby, 1888-antennae 8th greatly enlarged, 9th enlarged

(800) M. guatemalensis Jacoby, 1888-antennae 9th greatly enlarged, excavated

(801) M. jacobyi Bowditch, 1923-antennae 8th and 9th, extremely large

(802) M. pretiosa Jacoby, 1888-antennae 8th and 9th enlarged

(803) Metopoedema longicornis (Duvivier, 1891) - antennae extremely long, extended beyond elytra

(804) Metrobrotica furcata (Olivier, 1808)—clypeus with a small hole in the middle, surrounded by funnelshaped structure; antennae 3rd very long; protibia thickened

(805) M. geometrica (Erichson, 1847) —antennae 3rd and 4th enlarged

(806) Microlepta marginata Mohamedsaid, 1997-antennae 3 rd dilated

(807) Miltina dilatata Chapuis, 1875-antennae 4th-10th compressed, each segment with a long projection

(808) Mimastra andrewesi Bezděk, 2010_abdomen 2nd a tubercle in middle

(809) M. gracilis Baly, 1878-antennae 3rd-11th densely covered with long hairs

(810) M. procerula Zhang and Yang, 2006-abdomen 3rd and 4 th each with a triangular appendage on the posterior margin

(811) Momaea distincta Mohamedsaid, 1999-mesotibiaee excavated at apex, covered with long hairs; first segment of mesotarsus with a process projecting towards mesotibiae 
(812) Mombasa armicollis Fairmaire, 1884-protibia strongly dilated at apex

(813) M. magna (Weise, 1900)—protibiae strongly dilated at apex

(814) M. subinermis Fairmaire, 1884-protibiae strongly dilated at apex

(815) Monolepta armatipennis Medvedev, 2005-elytra postscutellar area with a drop-like impression, delimited by tubercle in front

(816) M. azlani Mohamedsaid, 1998-elytra with postscutellar cavities

(817) M. bicavipennis Chen, 1942-elytra with postscutellar cavities

(818) M. borneensis Mohamedsaid, 1993-elytra with oblique postscutellar cavities

(819) M. cavidorsis Fairmaire, 1893-elytra with broad postscutellar cavities

(820) M. cavipennis Baly, 1878-elytra with longitudinal cavities at sides

(821) M. c-alba (Jacoby, 1899) —elytra with postscutellar cavities

(822) M. cumingi (Weise, 1910)_elytra with posthumeral area strongly elevated, bearing oval shaped cavities

(823) M. danumica Mohamedsaid, 1993-elytra humpbacked, with deep, elongate postscutellar cavities

(824) M. dimidiata Jacoby, 1886-elytra with elongate cavities in middle

(825) M. discoidalis (Jacoby, 1895) - elytra with longitudinal postscutellar cavities, oblique, closed to suture

(826) M. flavicollis (Gyllenhal, 1808)—vertex strongly depressed

(827) M. foveipennis Medvedev, 2005-elytra with postscutellar cavities

(828) M. gantokensis Kimoto, 2004-elytra with large elongate cavities at sides

(829) M. hemorrhoidalis (Fabricius, 1801) - elytra with cavities in the middle

(830) M. impressipennis Oglobin, 1936-elytra with large postscutellar cavities

(831) M. kerangas Mohamedsaid, 1998-elytra humpbacked, with postscutellar cavities

(832) M. laysi Medvedev, 2002-elytra with shallow longitudinal impression at apex near suture

(833) M. malaysiana Mohamedsaid, 1993-elytra with broad postscutellar cavities

(834) M. marginipennis (Jacoby, 1892)—elytra with deep, elongate postscutellar cavities

(835) M. merah Mohamedsaid, 1993-elytra with spindleshaped cavities

(836) M. murphyi Mohamedsaid, 2002-elytra with cavities at sides
(837) M. posthumeralis Medvedev, 2005 elytra with large and shallow cavities at sides

(838) M. sargaonica Medvedev, 2005-elytra with postscutellar impression

(839) M. scutellaris Kimoto, 1989-elytra with longitudinally shallow postscutellar depression

(840) M. semifovea Mohamedsaid, 1993-elytra with shallow postscutellar cavities

(841) M. shirozui Kimoto, 1965-elytra with postscutellar cavities

(842) M. tarsata Medvedev, 2005-elytra with postscutellar impression

(843) M. tatemizo Kimoto, 2004-elytra with a pair of large longitudinal cavities at sides

(844) M. tibowensis Mohamedsaid, 2000-elytra humpbacked, with postscutellar cavities

(845) M. trochanterina Mohamedsaid, 1997-metatrochanters with a spine at the base

(846) M. vietnamica Kimoto, 1989-elytra with postscutellar longitudinal cavities near suture

(847) Monoleptocrania foveata (Olivier, 1801)—vertex deeply excavated, with margins protruded

(848) Neolaetana alternans Silfverberg, 1975-elytra with a pair of funnel-shaped cavities at base; antennae 3rd7th dilated

(849) N. basalis Laboissiere, 1921-elytra with a pair of funnel-shaped cavities at base; pronotum excavated at base; antennae $3 \mathrm{rd}-7$ th dilated

(850) N. freyi Silfverberg, 1975-elytra with a pair of funnel-shaped cavities at base; antennae 3rd-7th dilated

(851) N. neavei Laboissiere, 1923-elytra with a pair of funnel-shaped cavities at the base; pronotum excavated at the base; antennae $3 \mathrm{rd}-7$ th dilated

(852) N. neumanni (Weise, 1907) - elytra with a pair of funnel-shaped cavities at the base; pronotum excavated at the base; antennae 3rd-7th dilated

(853) Niasia bukat Reid, 1998-antennae 8th-11th enlarged, longitudinally grooved

(854) N. coeruleipennis Jacoby, 1899-antennae 8th-11th enlarged, longitudinally grooved

(855) N. difformis Jacoby, 1899-antennae 8th-11th enlarged, longitudinally grooved

(856) Nirina flavofasciata Laboissiere, 1940-antennae 6 th, 7th, 8th, and 9th enlarged

(857) N. regalis Laboissiere, 1940-antennae 8th and 9th enlarged

(858) N. imitans (Jacoby, 1894) -antennae 6th, 7th, 8th, and 9th enlarged

(859) Nirinoides abdominalis Jacoby, 1903-antennae very long, 5th-11th shortened, thickened 
(860) N. abyssinica (Jacoby, 1886) - antennae very long, 5 th-11th shortened, thickened

(861) N. staudingeri Jacoby, 1903-antennae very long, 5 th-11th shortened, thickened

(862) Nymphius buettikeri Medvedev, 1996-abdomen 1st with erect hairs, 2nd with a long appendage, truncated at apex, 3rd with a long appendage, rounded at apex; middle tibiae curved, dilated at apex

(863) N. ensifer (Guillebeau, 1891)—abdomen 3rd with a short appendage, blunt at apex, 4th tuberculate, 5th with a pair of long appendages, pointed at apex

(864) N. forcipifer (Weise, 1900)—abdomen 3rd with a broad appendages, bifurcate at apex, 4th with large transverse corrugations, 5th with a pair of long appendages, curved, dented at apex

(865) N. friedmani Lopatin, 2002-abdomen 1st covered with erect hairs, 2 nd with a long appendage, 3 rd with a long appendage, pointed at apex

(866) N. gianassoi Bezděk, 2008-abdomen 3rd with a broad, long appendage, tapered and setose at apex, 5 th with a pair of long appendages, blunt at apex

(867) N. lydius (Weise, 1886) —abdomen 3rd with a pair of very short appendages, 4th excavated, with a broad appendage

(868) N. ogloblini (Bogachev, 1947)—abdomen 3rd with a pair of long appendages, bent dorsally, blunt at apex, 4 th with a pair of long appendages, tapered at apex

(869) N. pravei (Jacobson, 1899)—abdomen 3rd with a long appendage, pointed at apex, 4th with a pair of lateral appendages

(870) N. stylifer (Weise, 1899) — abdomen 3rd with a pair of long appendages, bent ventrally, pointed at apex, 4th with a pair of long appendages

(871) Oidomorpha africana Laboissiere, 1924-antennae 7th triangularly dilated

(872) Oorlogia nigriceps Silfverberg, 1978-antennae 3rd9th dilated, flattened

(873) Ornithognathus aeneipennis Laboissiere, 1924-antennae 5th-9th enlarged

(874) Oroetes flavicollis Jacoby, 1888-clypeus excavated; antennae 10 segments, 3rd excavated, 4 th enlarged

(875) O. wilcoxi Blake, 1966-clypeus excavated; antennae 10 segments, 3rd and 4th excavated at apex; pronotum with a median knob at anterior margin

(876) Orthoxia boisduvalii Clark, 1865-antennae 4th-7th dilated

(877) Paleosepharia antennata Mohamedsaid, 2000-elytra with postscutellar extrusions deep, obliquely outward posteriorly

(878) P. barioensis Mohamedsaid, 2001—elytra with postscutellar extrusions deep, obliquely outward posteriorly
(879) P. basipennis Gressitt and Kimoto, 1963-elytra with postscutellar swelling and shallow cavities

(880) P. basituberculata Chen and Jiang, 1984—elytra with postscutellar extrusions straight, bordered at the base by a tubercle

(881) P. caudata Chen and Jiang, 1984-elytra with oval shaped postscutellar depression

(882) P. costata Takizawa and Basu, 1987-elytra with postscutellar extrusions deep, curved, parallel to suture

(883) P. excavata (Chujo, 1938) —elytra with postscutellar extrusions narrow, parallel to suture

(884) P. feae (Weise, 1892) —elytra with postscutellar extrusions shalllow

(885) P. flava Mohamedsaid, 2001-elytra with postscutellar extrusions straight, obliquely outward posteriorly

(886) P. fulvicornis Chen, 1942-elytra with postscutellar extrusions subparallel to suture

(887) P. fusiformis Chen and Jiang, 1984-elytra with postscutellar depression shallow, spindle shaped

(888) P. gongshana Chen and Jiang, 1986-elytra with postscutellar extrusions deep, spindle shaped

(889) P. haemorrhoidalis Medvedev, 2001-elytra with postscutellar extrusions deep spindle shaped

(890) P. humeralis Chen and Jiang, 1984-elytra with postscutelar extrusions obliquely outward, then inward posteriorly

(891) P. insignata Chen and Jiang, 1984-elytra with postscutellar extrusions straight then perpendicularly outward posteriorly

(892) P. jambuica Mohamedsaid, 1996-elytra with postscutellar extrusions deep, obliquely outward posteriorly

(893) P. joliveti Mohamedsaid and Constant, 2007-elytra with postscutellar extrusions subparallel to suture

(894) P. kolthoffli Laboissiere, 1938-elytra with postscutellar extrusions obliquely outward posteriorly

(895) P. kubani Medvedev, 2004-elytra with postscutellar extrusions deep, obliquely outward posteriorly

(896) P. lambirica (Mohamedsaid, 1993)—elytra with postscutellar extrusions deep, obliquely outward posteriorly

(897) P. lamrii Mohamedsaid, 1999—elytra with postscutellar extrusions obliquely outward posteriorly

(898) P. lawa Mohamedsaid, 2001-elytra with postscutellar extrusions deep, obliquely outward posteriorly

(899) P. legenda Mohamedsaid, 1996-elytra carinate at sides, with postscutellar extrusions deep, obliquely outward posteriorly

(900) P. limbangica (Mohamedsaid, 1993) —elytra with postscutellar extrusions shallow, obliquely outward posteriorly 
(901) P. lineata Mohamedsaid, 2000-elytra with postscutellar extrusions semicircular shaped

(902) P. lingulata Chen and Jiang, 1984-pronotum with a tongue like projection at the middle of posterior margin

(903) P. liquidambara Gressitt and Kimoto, 1963-elytra with postscutellar suture strongly raised

(904) P. malayana Mohamedsaid, 1996 — elytra with postscutellar extrusions broad, deep, spindle shaped

(905) P. marginata Mohamedsaid, 1996-elytra with postscutellar extrusions obliquely outward posteriorly

(906) P. medvedevi Bezděk, 2008-elytra with postscutellar extrusions deep, obliquely outward posteriorly

(907) P. orbiculata Chen and Jiang, 1984-elytra with oval shaped postscutellar depression

(908) P. persimilis Kimoto, 1989-elytra with postscutellar extrusions obliquely outward posteriorly

(909) P. piceipennis Kimoto, 1989-elytral with postscutellar extrusions deep and obliquely outward posteriorly

(910) P. posticata Chen, 1942-elytra with postscutellar suture strongly raised, obliquely outward posteriorly

(911) P. quercicola Chen and Jiang, 1984-elytra with postcutellar extrusions straight, then obliquely outward postseriorly

(912) P. reducta Medvedev, 2001—elytra with postscutellar extrusions small

(913) P. rompinica Mohamedsaid, 1996-elytra with postscutellar extrusions narrow, hook-like

(914) P. rubromarginata Medvedev, 2001—pronotum shallowly grooved in the middle, covered with short hairs; metatibiae emarginate at apex

(915) P. scutellaris Kimoto, 1989-elytra with postscutellar extrusions shallow, parallel to suture

(916) P. subnigra Gressitt and Kimoto, 1963-elytra with postscutellar suture slightly raised

(917) P. tarsalis Mohamedsaid, 1996-elytra with postscutellar extrusions deep, hook like

(918) P. tenasserimensis (Maulik, 1936)—elytra with postscutellar extrusions broad, obliquely outward posteriorly

(919) P. truncata Laboissiere, 1936-elytra with postscutellar extrusions obliquely outward posteriorly

(920) P. verticalis Chen and Jiang, 1984-elytra with postscutellar extrusions long, obliquely outward, then parallel to suture

(921) P. vietnamica Medvedev, 2004-elytra with postscutellar extrusions obliquely outwards posteriorly

(922) P. zakrii Mohamedsaid, 1996-elytra with postscutellar extrusions deep, obliquely posteriorly
(923) Palpaenidea labeonis Laboissiere, 1933-clypeus deeply excavated, with a bifurcated projection hanging from frons; maxillary palpi swollen; antennae 4 th with a spine at apex

(924) P. pallipes (Fabricius, 1801)—clypeus deeply excavated, with a pair of sharp projection hanging from frons; maxillary palpi swollen

(925) Palpoxena abdominalis Laboissiere, 1926-clypeus excavated; maxillary palpi swollen

(926) P. albicans (Jacoby, 1900)—clypeus excavated; maxillary palpi swollen

(927) P. apicalis (Jacoby, 1889)—clypeus excavated; maxillary palpi swollen

(928) P. barbata (Baly, 1879)—clypeus deeply excavated, with tuft of hairs and a small process; labrum extremely large; maxillary palpi swollen

(929) P. carinata Bryant, 1960-clypeus excavated; maxillary palpi swollen

(930) P. clavareaui (Jacoby, 1903)—clypeus excavated; maxillary palpi swollen

(931) P. cocinnea (Jacoby, 1899)—clypeus deeply excavated, with a tooth-like projection in the middle; maxillary palpi swollen

(932) P. coeruleipennis (Baly, 1888)—clypeus deeply excavated; front with tuft of very long hairs hanging on the cavity; labrum extremely large; maxillary palpi swollen

(933) P. crassipalpis (Jacoby, 1892)—clypeus excavated, bituberculate anteriorly; maxillary palpi swollen

(934) P. dilaticornis (Jacoby, 1896)-clypeus openly excavated, with channels at sides; antennae 3rd-11th longitudinally ridged

(935) P. divisa (Jacoby, 1894)—clypeus deeply excavated, with a pointed projection hanging from frons; maxillary palpi swollen

(936) P. ertli (Weise, 1903)—clypeus excavated; maxillary palpi swollen

(937) P. eximia (Baly, 1879)—clypeus deeply excavated, with projection hanging from frons and two coils of hairs from cavity; labrum extremely large

(938) P. facialis (Baly, 1886)—clypeus deeply, broadly excavated; labrum extremely large; antennae 3rd enlarged, dilated at apex

(939) P. fissipes (Laboissiere, 1924)—clypeus excavated; maxillary palpi swollen

(940) P. flava (Laboissiere, 1939)—clypeus excavated; maxillary palpi swollen

(941) P. gracilis (Jacoby, 1889)—clypeus excavated; middle tibiae with elongate appendage at apex

(942) P. hauseri (Weise, 1903)_clypeus excavated; maxillary palpi swollen 
(943) P. jacobyi (Baly, 1888)—clypeus openly excavated; maxillary palpi large, flattened, triangular

(944) P. juno Weise, 1912-clypeus excavated; maxillary palpi swollen

(945) P. konbirensis (Weise)—clypeus openly excavated, with tuft of erect hairs; maxillary palpi swollen

(946) P. laeta (Baly, 1861)-clypeus openly excavated; maxillary palpi extremely large, deformed

(947) P. latifrons (Baly, 1904)-clypeus openly, deeply excavated, with an upright process in the middle; labrum very large

(948) P. longicornis (Jacoby, 1895)—clypeus deeply excavated, with lateral boundaries channelled

(949) P. marginata (Laboissiere, 1920)_clypeus deeply excavated, with a broad projection in the middle

(950) P. modesta (Jacoby, 1896)—clypeus flat, antennae 3rd-8th thickened

(951) P. nasika Maulik, 1936-clypeus deeply excavated, with wedge-shaped structure in middle; labrum very large

(952) P. nasuta (Westwood, 1837)—clypeus deeply excavated, divided by a middle concave structure; labrum very large

(953) P. nigromarginata (Jacoby, 1895)—clypeus deeply excavated, divided by a central ridge

(954) P. pallida (Jacoby, 1896)_clypeus openly excavated; labrum very large; antennae 4 th-11 th keeled on inner surface

(955) P. patrizii (Laboissiere, 1937)—clypeus deeply excavated, with a narrow projection in the middle

(956) P. pilicornis (Jacoby, 1896)—clypeus deeply excavated, with projection hanging from frons; labrum very large, excavated on each side

(957) P. praetoriae (Gahan, 1892)—clypeus excavated; antennae 1st enlarged

(958) P. rufipennis (Jacoby, 1887)—clypeus deeply excavated, with a projection hanging on frons

(959) P. rufofulva (Jacoby, 1896)—clypeus slightly excavated, with orifice bearing erect hairs; maxillary palpi swollen

(960) P. sabahensis Mohamedsaid, 1997-clypeus deeply excavated, with a broad projection hanging on frons; labrum large; maxillary palpi swollen

(961) P. sumatrensis (Jacoby, 1884)—clypeus deeply excavated, with a narrow projection in the middle; antennae 7 th enlarged

(962) P. truncatipennis (Jacoby, 1896)_clypeus deeply excavated, with a projection

(963) P. ugandensis (Laboissiere, 1937)_clypeus deeply excavated; maxillary palpi swollen
(964) P. variabilis (Jacoby, 1886)—clypeus deeply excavated with a broad triangular projection hanging on frons; labrum very large, triangular; maxillary palpi swollen

(965) P. violaceipennis (Jacoby, 1896)—clypeus extensively excavated, with coiled bunch of hairs at sides; labrum very large; maxillary palpi greatly swollen

(966) P. viridis (Hope, 1831)—clypeus openly excavated, with a tuft of hairs; maxillary palpi swollen

(967) Parabrotica flavipenn (Blake, 1966)_protibiae thickened; mesotibiae notched

(968) P. rhabdotus (Blake, 1966) - antennae 8th-10th thickened; mesotibiae notched

(969) P. subtilis (Weise, 1921)—mesotibiae notched

(970) Paracanthina vicina (Gahan, 1909)—pronotum elevated with a sharp edge near posterior margin; elytra with a pair of tubercles at the base

(971) P. multicolor (Weise, 1912)_pronotum elevated with a sharp edge near posterior margin; elytra with a pair of tubercles at the base

(972) Paraplotes antennalis Chen, 1942-antennae 11th enlarged

(973) P. clavicornis Gressitt and Kimoto, 1963-antennae 8th-11th enlarged

(974) P. indica Takizawa and Basu, 1987-antennae 4th10th enlarged; clypeus depressed medially

(975) Parasbecesta costalis (Weise, 1912) —antennae 7th11th enlarged

(976) P. feai (Laboissiere, 1937)-antennae 6th-9th enlarged

(977) P. festiva (Laboissiere, 1919) - antennae 7th-9th enlarged

(978) P. flavonigra Laboissiere, 1940-antennae 7th-11th enlarged

(979) P. rubida Laboissiere, 1940-antennae 8th-11th enlarged

(980) P. ruwensorica (Weise, 1912)-antennae 6th-9th enlarged

(981) Paratriarius alternans (Weise) - elytra with a pair of sutural depressions at apex

(982) P. argo Bowditch, 1911-elytra with a pair of tubercles at sutural apex

(983) P. balyi (Jacoby, 1879) —elytra with sutural depressions at apex

(984) P. boucardi (Bowditch, 1912) - elytra with a pair of sutural depressions at apex

(985) P. castanea (Bowditch, 1911)—elytra with a pair of long ridges at apex

(986) P. dorsatus (Say, 1824) —antennae 5th, 6th, and 7th enlarged; elytra with a broad sutural depression at apical fifth and bearing tubercle 
(987) P. neocrassicornis (Bowditch, 1911)—antennae 7th, 8 th, and 9 th enlarged

(988) P. nigrotibialis (Bowditch, 1911) —elytra with a pair of broad tubercles at apex

(989) P. verrucosa (Jacoby, 1880)—elytra with a pair of tubercles near suture at apex

(990) Paridea allardi Kimoto, 1989—elytra with postscutellar cavities bordered by short ridges

(991) P. apicata Medvedev, 2004-elytra with postscutellar cavities bordered by sharp ridges

(992) P. approximata Duvivier, 1892 —elytra with tubercle at sutural apical angle

(993) P. avicauda (Laboissiere, 1930)_elytra with deep postscutellar cavities parallel to suture

(994) P. biplagiata (Fairmaire, 1889) —elytra with a pair of cavities at sides bearing tubercles

(995) P. cornuta Jacoby, 1892-elytra with a pair of short hooks near suture

(996) P. dohertyi Maulik, 1936-elytra with postscutellar area faintly delimited

(997) P. excavata Kimoto, 1989-elytra with postscutellar cavities

(998) P. flava Medvedev and Samoderzhenkov, 1989elytra with postscutellar cavities

(999) P. flavipennis (Laboissiere, 1930)_elytra with postscutellar area elevated

(1000) P. foveipennis Jacoby, 1892-elytra with deep postscutellar cavities bordered by elevated sutures

(1001) P. lateralis Medvedev and Samoderzhenkov, 1989elytra with postscutellar cavities shallow

(1002) P. multituberculata Medvedev and Samoderzhenkov, 1989-elytra with two pair of tubercles in basal area

(1003) P. nigrocephala (Laboissiere, 1930)_elytra with postscutellar cavities bearing tufted process

(1004) P. tuberculata Gressitt and Kimoto, 1963-elytra with a pair of large tubercles in apical area

(1005) Periclitena cyanea (Clark, 1865)_antennae 8th enlarged, excavated

(1006) P. sinensis (Fairmaire, 1888)—antennae 8th enlarged, excavated

(1007) Phyllecthris dorsalis (Olivier, 1808)-antennae 10 segments; middle tibiae notched on the inner side

(1008) P. gentilis Leconte, 1865-antennae 10 segments; mesotibiae notched on the inner side

(1009) P. texanus Leconte, 1884-antennae 10 segments; mesotibiae notched on the inner side

(1010) Phyllobrotica antennata Schaeffer, 1932-antennae 11 th enlarged

(1011) P. elegans Kraatz, 1866-abdomen 2nd with a pair of processes arose from posterior margin of the sternite and connected by subtriangular lamella
(1012) P. frontalis Weise, 1886 - abdomen 2nd with a pair of tubercles and not connected with each other

(1013) P. malinka Bezděk, 2010-abdomen 2nd with two small groups of longer hairs in the middle; 3rd with a pair of tubercles connected by transverse lamella

(1014) P. nigripes Horn, 1893-abdomen 3rd with a pair of tubercles and not connected with a subtriangular lamellate in the middle

(1015) P. vittata Horn, 1893-metafemora enlarged

(1016) Phyllobroticella flava Jacoby, 1894-antennae 3rd strongly triangularly dilated, deeply emarginated, 4th dilated; elytra deeply excavated at the base

(1017) P. ferruginea Laboissiere, 1924-antennae 3rd strongly triangularly dilated, deeply emarginated, 4th dilated; elytra deeply excavated at the base

(1018) P. kraatzi Weise, 1902-antennae 3rd strongly triangularly dilated, deeply emarginated, 4th dilated; elytra deeply excavated at the base

(1019) P. maynei Laboissiere, 1924-antennae 3rd strongly triangularly dilated, deeply emarginated, 4th dilated; elytra deeply excavated at the base

(1020) P. nigripennis Laboissiere, 1924-antennae 3rd strongly triangularly dilated, deeply emarginated, 4 th dilated; elytra deeply excavated at the base

(1021) P. pallida Laboissiere, 1924-antennae 3rd strongly triangularly dilated, deeply emarginated, 4th dilated; elytra deeply excavated at the base

(1022) P. simplicipennis Jacoby, 1903 — antennae 3rd strongly triangularly dilated, slightly emarginated, 4th dilated; elytra deeply excavated at the base

(1023) Pimentelia kuanduensis Laboissiere, 1939—antennae 4th-8th enlarged

(1024) Platybrotica misionensis Cabrera and Walsh, 2004antennae 6th-10th enlarged, excavated ventrally

(1025) Platymorpha homoia Blake, 1966-protibiae broadened; mesotibiae with a shallow notched

(1026) P. variegata Jacoby, 1888-protibiae strongly dilated at apex

(1027) Platyxantha apicicornis Jacoby, 1903-antennae 10th and 11th dilated

(1028) P. bicolor Jacoby, 1906-antennae curved, with long hairs

(1029) P. borlei Laboissiere, 1931-antennae thickened

(1030) P. calabariensis Laboissiere, 1931—antennae slightly curved, with long hairs

(1031) P. carinata Weise, 1912-protibiae curved

(1032) P. coerulescens (Weise, 1922)_antennae with long hairs

(1033) P. citernii Jacoby, 1899-antennae 5th-10th curved

(1034) P. conradti Jacoby, 1903-metatibiae with a long process 
(1035) P. curvicornis Jacoby, 1894-antennae 4th-8th curved; eyes large

(1036) P. discoidalis Jacoby, 1895-antennae 4th-8th thickened

(1037) P. fascialis Jacoby, 1899 — antennae with long hairs

(1038) P. fuscitarsis Weise, 1903-antennae 3rd-9th curved

(1039) P. kraatzi Weise, 1903 — antennae 4th-6th curved

(1040) P. livingstoni Jacoby, 1899_antennae with long hairs

(1041) P. longicornis Jacoby, 1903-antennae 3rd-8th curved, with long hairs

(1042) P. lukunguensis Jacoby, 1899-antennae with long hairs

(1043) P. lusingana Bryant, 1958-antennae 3rd-6th curved

(1044) P. minor Weise, 1903-antennae 4th, 5th, and 6th curved, with long hairs

(1045) P. nigromarginata Jacoby, 1895-antennae 5th-8th curved

(1046) P. pallipes Laboissiere, 1940-antennae 4th-8th curved

(1047) P. pauli Weise, 1903-antennae 3rd-9th thicker, curved

(1048) P. sutteri Laboissiere, 1939-antennae 3rd-10th dilated

(1049) P. tenella Weise, 1903 — antennae with long hairs

(1050) P. trichroa Laboissier, 1931 — antennae 3rd-9th thickened; hind tibia with an elongated process at apex

(1051) P. versicolor Laboissiere, 1921-antennae 3rd-9th thickened

(1052) P. verticalis Laboissiere, 1931-antennae 3rd-10th thickened

(1053) Porechontes albiventris (Blake, 1958)—clypeus with a pore in middle, below antennal socket; middle tibiae notched

(1054) P. wilcoxi Blake, 1958-clypeus with a pore in the middle, below antennal socket; antennae 3rd compressed, 8th and 9th triangularly dilated; mesotibiae notched

(1055) P. limbella (Weise, 1921)_clypeus with a deep pore in the middle, below antennal socket; antennae 9th broadened; mesotibiae notched; eyes large

(1056) Prosmidia bispinosa (Fabricius, 1798)—pronotum with oblique ridge at the base on each side of midline; elytra with a pair of tubercles at the base

(1057) P. chevrolati (Guerin-Menevile, 1849)—pronotum with an elevation along midline in posterior half; scutellum tongue shaped; elytra with a pair of tubercles at base

(1058) P. concinna (Weise, 1905)—pronotum with ridge-like elevation at posterior margin; elytra with a pair of tubercles at the base
(1059) P. conifera (Fairmaire, 1882)_pronotum with a sharp, oblique ridge at the base on each side of midline; elytra with a pair of tubercles at the base

(1060) P. decempunctata (Laboissiere, 1926)—pronotum with a raised knob at the middle of posterior margin; elytra with a pair of tubercles at the base

(1061) P. dregei (Chapuis, 1876)—pronotum with a raised knob at the middle of posterior margin; elytra with a pair of tubercles at the base

(1062) P. excavata (Weise, 1909)_-pronotum with a kidney shaped cavity; scutellum tongue-shaped; elytra with three tubercles at the base

(1063) P. hastata (Laboissiere, 1921)_pronotum with a raised knob at the middle of posterior margin; elytra with a pair of tubercles at the base

(1064) P. magna (Weise, 1904)—pronotum with a pair of projections at the middle of posterior margin; elytra with a pair of tubercles at the base

(1065) P. passeti (Allard, 1888)—pronotum with a raised knob at the middle of posterior margin; elytra with a pair of tubercles at the base

(1066) P. prasina Silfverberg, 1972-elytra with a pair of tubercles at the base

(1067) P. sarcedos Silfverberg, 1973-pronotum with a raised knob at middle of posterior margin; elytra with a pair of tubercles at the base

(1068) P. semifasciata Silfverberg, 1973-pronotum with an elevation on midline in posterior half; elytra with a pair of tubercles at the base

(1069) P. sexplagiata (Jacoby, 1894)—pronotum with a raised knob at the middle of posterior margin; elytra with a pair of tubercles at the base and at apex

(1070) P. suahelorum Weise, 1901-pronotum with the posterior margin forms a short, blunt process; scutellum narrow, tongue shaped; elytra with a pair of tubercles at base

(1071) P. suturalis (Jacoby, 1908)—pronotum with a raised knob at the middle of posterior margin; elytra with a pair of tubercles at the base

(1072) P. vicina (Gahan, 1909)-elytra with a pair of tubercles at the base

(1073) P. zavattarii Laboissiere, 1938-pronotum with an elevation along midline in posterior half; elytra with a pair of tubercles at the base

(1074) Pseudaenidea limbata Laboissiere, 1938-clypeus deeply excavated, with long hairs

(1075) P. monardi Laboissiere, 1939_clypeus deeply excavated, with long hairs

(1076) Pseudocophora ambusta (Erichson, 1834)-elytra with deep postscutellar cavities bearing tubercles

(1077) P. apicalis Laboissiere, 1932-elytra with deep postscutellar cavities bearing tubercles 
(1078) P. bicolor Jacoby, 1887-elytra with deep postscutellar cavities bearing tubercles

(1079) P. brunnea Baly, 1886-elytra with deep postscutellar cavities bearing tubercles

(1080) P. buquetii (Guerin-Meneville, 1830)_elytra with deep postscutellar cavities bearing tubercles

(1081) P. carinata Yang, 1991-elytra with deep postscutellar cavities and bordered with sharp edge

(1082) P. cochleata Yang, 1991-elytra with deep postscutellar cavities bearing pointed tubercles

(1083) P. distincta Baly, 1888-elytra with deep postscutellar cavities bearing tubercles

(1084) P. erichsoni Baly, 1888 —elytra with deep postscutellar cavities bearing tubercles

(1085) P. flaveola Baly, 1888-elytra with deep postscutellar cavities bearing tubercles

(1086) P. flavipes Weise, 1913-elytra postscutellar cavities with tubercles

(1087) P. javanensis Laboissiere, 1932—elytra postscutellar cavities with tubercles

(1088) P. inornata Jacoby, 1893-elytra postscutellar cavities with tubercles

(1089) P. madoni Laboissiere, 1940-elytra postscutellar cavities with tubercles

(1090) P. monticola Weise, 1913-elytra postscutellar cavities with tubercles

(1091) P. nicobarica Jacoby, 1898-elytra postscutellar cavities with tubercles

(1092) P. nitens Allard, 1887-elytra postscutellar cavities with tubercles

(1093) P. pectoralis Baly, 1888-elytra postscutellar cavities shallow

(1094) P. perplexa Baly, 1888-elytra postscutellar cavities with tubercles

(1095) P. philippinensis Laboissiere, 1940-elytra postscutellar cavities with tubercles

(1096) P. praeusta Allard, 1889-elytra postscutellar cavities with tubercles

(1097) P. sumatrana Jacoby, 1896-elytra postscutellar cavities with tubercles

(1098) P. uniplagiata Jacoby, 1884-elytra postscutellar cavities with tubercles

(1099) P. ventralis Weise, 1913-elytra postscutellar cavities with tubercles

(1100) P. wallacei Baly, 1888-elytra postscutellar cavities with tubercles

(1101) Pseudocrania basalis Jacoby, 1907-elytra with large, deep, spindle-shaped postscutellar cavities

(1102) P. semifulva Bryant, 1953-elytra with narrow extrusions curving obliquely outward posteriorly
(1103) Pseudoluperus tuberculatus (Blake, 1942)—abdomen 2nd with a pair of tubercles

(1104) Pseudorupilia bicostata (Allard, 1889)-antennae 8th-11th dilated

(1105) P. sexlineata (Fabricius, 1781) - antennae 8th-11th dilated

(1106) Pseudoscelida antennata (Mohamedsaid, 2001) antennae with long hairs, 8th enlarged, oblong; eyes large

(1107) P. biru Mohamedsaid, 2001-antennae with long hairs, 3rd enlarged, excavated, 4th enlarged, excavated, 5th-10th thickened, concave

(1108) P. indica Jacoby, 1903 — antennae with long hairs

(1109) P. pallida Jacoby, 1894 — antennae with long hairs

(1110) Pseudoshaira warchalowskii Beenen, 2007-antennae 3rd-11th strongly dilated

(1111) Rachicephala vittatipennis (Jacoby, 1887)—clypeus excavated, with projection on each side above labrum, and a long median spine below antennal socket

(1112) Rohaniella megalophthalma Laboissiere, 1921-eyes large, antennae 4 th-10th curved

(1113) Ruwenzoria viridis Laboissiere, 1919-antennae 7th curved, dilated

(1114) Samoria bipunctata (Laboissiere, 1921)—antennae 3rd-7th dilated, compressed

(1115) S. collarti (Laboissisre, 1932)-antennae 3rd-7th dilated, compressed

(1116) S. fastuosa Silfverberg, 1982-antennae 3rd-7th dilated, compressed

(1117) S. jeanelli (Laboissiere, 1918)-antennae 3rd-7th dilated, compressed

(1118) S. oculata (Laboissiere, 1891)—antennae 3rd-7th dilated, compressed

(1119) S. opulenta (Peringuey, 1892)-antennae 3rd-7th dilated, compressed

(1120) S. violacea (Allard, 1888)_antennae 3rd-7th dilated, compressed

(1121) Sarawakiola ajaib Mohamedsaid, 1997-antennae 1st rounded, extremely large, deformed; vertex deeply, transversely grooved; frontal tubercles larged, with a pair of spine

(1122) Scelida balyi Jacoby, 1878-abdomen 2nd with a pair of large appendages

(1123) S. flaviceps (Horn, 1893)_abdomen 2nd with a pair of large appendages

(1124) S. nigricornis (Jacoby, 1888)—abdomen 1st with a broad, deep depression in the middle; metatibiae curved 
(1125) Scelidacne andrewi Clark, 1998-abdomen 3rd with trilobed appendage, the lateral densely pubescent, the median glabrous and bifurcate at apex; metatibiae with a curved appendage at apex

(1126) Scelolyperus bimarginatus (Blake, 1928)—metatibiae straight, with a thin lamellate lobe at apex

(1127) S. curvipes Wilcox, 1965-metatibiae strongly curved, with inner side glabrous

(1128) S. hatchi Wilcox, 1965-metatibiae straight, with a flat lobe at apex

(1129) S. kroliki Borowiec, 2005-metatibiae curved

(1130) S. liriophilus Wilcox, 1965-metatibiae with a lamellate lobe at apex

(1131) S. loripes Horn, 1893-metatibiae curved, with inner side pubescent

(1132) S. meracus (Saya, 1826)—metatibiae with a lamellate lobe at apex

(1133) S. megalurus Wilcox, 1965-metatibiae curved

(1134) S. nigrocyaneus (Leconte, 1879)—metatibiae curved, with a ridged lobe at apex

(1135) S. nigrovirescens (Fall, 1910)—metatibiae straight, with a thin lamellate lobe at apex

(1136) S. ratulus Wilcox, 1965-metatibiae curved

(1137) S. schwarzi Horn, 1893-metatibiae strongly curved

(1138) S. smaragdinus (Leconte, 1859)—metatibiae curved

(1139) S. tejonicus Crotch, 1874-metatibiae strongly curved, with a prominent tooth

(1140) S. wilcoxi Hatch, 1971-metatibiae weakly curved

(1141) Schematiza bicolor Jacoby, 1887-antennae 3rd-7th dilated

(1142) S. clakri Jacoby, 1887-antennae 3rd-7th dilated

(1143) S. funereal Jacoby, 1889-antennae 3rd-7th dilated

(1144) S. thoracica Jacoby, 1887-antennae 3rd-7th dilated

(1145) S. unistriata Jacoby, 1889-antennae 3rd-7th dilated

(1146) Sermyloides basalis Jacoby, 1884-clypeus strongly depressed; antennae 3rd compressed, triangular shaped

(1147) S. bicolor Jacoby, 1896-clypeus strongly depressed; antennae 3rd compressed, triangular shaped

(1148) S. biconcava Yang, 1991-clypeus strongly depressed; antennae 3rd compressed, triangular shaped

(1149) S. biuncita Yang, 1991—clypeus strongly depressed; antennae 3rd compressed, triangular shaped

(1150) S. coomani Laboissiere, 1936-clypeus shallowly excavated, with a pair of tubercles; antennae 3rd dilated

(1151) S. cribellata Yang, 1991—clypeus strongly excavated, with a pair of tubercles

(1152) S. cuspidata Yang, 1991-clypeus strongly depressed; antennae 3rd elongated, curved
(1153) S. decorata Chen, 1942-clypeus deeply excavated, with hairy ridge on borders

(1154) S. dilaticornis Jacoby, 1892-clypeus excavated; antennae 3rd compressed, triangular shaped

(1155) S. filiforma Mohamedsaid, 2001-clypeus excavated, with a pair of tubercles

(1156) S. inornata Chen, 1942-clypeus excavated with smooth borders

(1157) S. maculatipennis Kimoto, 1989-clypeus excavated; antennae 3rd very long

(1158) S. major Kimoto, 1989-clypeus excavated; antennae 3rd compressed, triangular shaped

(1159) S. negeriensis Mohamedsaid, 2001-clypeus excavated, with a pair of tubercles

(1160) S. nideki Mohamedsaid, 2002-clypeus excavated; antennae 3rd compressed, triangular shaped

(1161) S. nigripennis Gressitt and Kimoto, 1963-clypeus excavated, with projection in the middle; antennae 3rd extremely long

(1162) S. pallicornis (Fabricius, 1801)—clypeus excavated; antennae 3rd compressed, triangular shaped

(1163) S. philippinensis Jacoby, 1895-clypeus excavated; antennae 3rd compressed, curved

(1164) S. pilosa Yang, 1991-clypeus strongly depressed; antennae 3rd compressed, triangular shaped

(1165) S. pilifera Yang, 1991-clypeus strongly depressed; antennae 3rd compressed, triangular shaped

(1166) S. semiornata Chen, 1942-clypeus excavated; antennae 3rd moderately dilated

(1167) S. sexmaculata Yang, 1991—clypeus strongly depressed; antennae 3 rd very long

(1168) S. sulcata Yang, 1991-clypeus strongly depressed; antennae 3rd compressed, triangular shaped

(1169) S. tompok Mohamedsaid, 2001—clypeus excavated, with a pair of tubercles; antennae 3rd compressed, triangular shaped

(1170) S. umbonata Yang, 1991-clypeus strongly depressed, with a pair of tubercles; antennae 3rd compressed, curved

(1171) S. unicolor Mohamedsaid, 1997-clypeus strongly depressed; antennae 3rd enlarged, compressed, triangular shaped

(1172) S. variabilis Kimoto, 1989-clypeus depressed; antennae 3rd very long, curved in the middle

(1173) S. varicolor Chen, 1942-clypeus deeply excavated, with overhanging projection on frons; antennae 3rd elongate, curved

(1174) S. vittipennis Duvivier, 1891-clypeus strongly depressed; antennae 3rd curved, moderately dilated

(1175) S. wangi Yang, 1993-clypeus strongly depressed; antennae 3rd compressed, triangular shaped 
(1176) S. yunnanensis Yang, 1991-clypeus strongly depressed, with two pairs of four tubercles; antennae 3rd cylindrical

(1177) Sesselia apicalis Laboissiere, 1937-antennae 8th11th thickened

(1178) Shungwayana trifasciata (Allard, 1888)-antennae 3rd-7th dilated, compressed

(1179) Sikkimia antennata Duvivier, 1891-antennae 10th enlarged, oblong, 11th enlarged, excavated

(1180) S. kabakovi (Lopatin, 2003)—antennae 10th enlarged, excavated, 11th enlarged, excavated

(1181) S. miranda (Lopatin, 2003)_-antennae 10th enlarged, excavated, 11th enlarged, excavated

(1182) S. rufa (Chen, 1964)_-antennae 10th enlarged, excavated, 11th enlarged, excavated

(1183) Simopsis neobroticoides Blake, 1966-antennae 3rd compressed, 4 th-8th thickened; front tibiae dilated at apex; middle tibiae notched

(1184) Sinoluperoides antennatus Kimoto, 1989-antennae 2nd-11th with long hairs

(1185) Sonchia sternalis (Faimaire, 1888)_elytra with a pair of tubercles at apex near suture

(1186) Spilocephalus apicalis Jacoby, 1906-antennae 3rd6th enlarged, compressed; maxillary palpi swollen

(1187) S. intermedius Jacoby, 1895-clypeus deeply excavated divided by a median ridge; antennae 3rd-6th enlarged, curved

(1188) S. metallicus Jacoby, 1894-antennae with long hairs, 3rd-6th curved; eyes large

(1189) Spilonotella sagax (Weise, 1902)_antennae 3rd-7th dilated, 8th, 9th, and 10th dilated, compressed

(1190) Stenellina impressicollis Weise, 1912-antennae very long, with long hairs

(1191) S. limbata (Laboissiere, 1920)_antennae very long, with long hairs

(1192) S. marginata (Weise, 1902)—antennae very long, with long hairs

(1193) S. meruensis Weise, 1909-antennae very long, with long hairs

(1194) Stenoplatys parvicollis Laboissiere, 1936-antennae 3rd elongate globose, 4th shortened, 9th and 10th dilated

(1195) S. picea (Fabricius, 1781)_antennae 9th and 10th dilated; front tibiae curved

(1196) Strobiderus excavatus Jacoby, 1884—elytra with cavities at apex

(1197) Synetocephalus crassicornis (Fall, 1910)—antennae 4th-11th thickened

(1198) S. curvatus (Fall, 1910)_pro-, meso-, and metatibiae curved
(1199) Taenala divisa (Gerstaecker, 1855)_antennae 3rd7 th dilated; pronotum with a small process in the middle of posterior margin

(1200) T. adumbrata Silfverberg, 1978-antennae 3rd-7th dilated; pronotum with a small process in the middle of posterior margin

(1201) Taphinella nigripennis Jacoby, 1889-antennae 4th10th dilated, compressed

(1202) Taumacera apicalis (Baly, 1864) —antennae 9th-10th dilated, 11th enlarged, oblong; metasternum with posterior process; metatibiae with a long, pointed process at apex

(1203) T. auripennis (Laboissiere, 1933)—antennae 3rd enlarged, globose, 8 th reniform

(1204) T. azurea (Laboissiere, 1933)—antennae 3rd enlarged, globose, 8 th arcuate

(1205) T. bella (Weise, 1922)-antennae 8th and 9th enlarged, excavated; clypeus excavated, with a thin acute ridge in the middle

(1206) T. bifasciata (Jacoby, 1889) —antennae 9th enlarged, 10 th enlarged, excavated, 11 th longitudinally excavated; metasternum with posterior process

(1207) T. bicornuta (Medvedev, 2001)—clypeus deeply excavated, bordered with conical horn

(1208) T. centromaculata Medvedev, 2008-antennae 3rd enlarged, oblong, excavated; metasternum with posterior process

(1209) T. constricta Mohamedsaid, 2002-antennae 3rd enlarged, oblong, excavated; metasternum with posterior process

(1210) T. costatipennis (Jacoby, 1896)-antennae 3rd elongate-cylindrical; metasternum with posterior process

(1211) T. dekatevi Reid, 2001-antennae 3rd enlarged, ovoid, deeply excavated; metatibiae excavated in the middle; metasternum with posterior process

(1212) T. deusta Thunberg, 1814-antennae 3rd enlarged, oblong ovate, excavated; metasternum with posterior process

(1213) T. dohertyi (Jacoby, 1894)-antennae 5th and 6th enlarged; metasternum with posterior process

(1214) T. duri Mohamedsaid, 2000_antennae 3rd enlarged, oblong, with a spine; metasternum with posterior process

(1215) T. evi Reid, 1999-antennae 3rd enlarged, oblong, deeply excavated; metasternum with posterior process

(1216) T. frontalis Mohamedsaid, 2001-antennae 3rd strongly dilated; clypeus deeply excavated, with a projection; metasternum with posterior process

(1217) T. fulvicollis Jacoby, 1881-antennae 3rd enlarged, oblong; metasternum with posterior process 
(1218) T. indica (Jacoby, 1889)—antennae 3rd broadly triangular, 8th dilated, 9th enlarged; clypeus deeply excavated; metasternum with posterior process

(1219) T. insignis (Baly, 1864)-antennae 9th extremely large, globose, 10th enlarged, longer than broad, oblong; metasternum with posterior process; metatibiae with a short process at apex

(1220) T. insularis (Gressitt and Kimoto, 1963)-antennae 6 th enlarged, 9th and 10th constricted in the middle, oblong; clypeus transversely depressed

(1221) T. khalednordini Mohamedsaid, 2010-antennae 1st and 3rd extremely large; metasternum with posterior process

(1222) T. kinabaluensis (Mohamedsaid, 1999)—metasternum with posterior process; metatibiae with a very long process at apex

(1223) T. laevipennis (Jacoby, 1886)-antennae 3rd enlarged, oblong; metasternum with posterior process

(1224) T. maculata (Baly, 1886)_antennae 3rd enlarged, oblong, deeply excavated; metasternum with posterior process

(1225) T. magenta (Gressitt and Kimoto, 1963)—antennae 6 th and 7 th enlarged

(1226) T. midtibialis Mohamedsaid, 1998-antennae 3rd enlarged, globular, 4th-11th longitudinally ridged; mesotibiae excavated; metasternum with posterior process; metatibiae with short process at apex

(1227) T. mohamedsaidi Reid, 1999-antennae 3rd enlarged, globular, 4th distorted and angularly excavated; clypeus excavated; protibiae excavated in the middle; metasternum with posterior process

(1228) T. monstrosa (Jacoby, 1899) —antennae 9th very large, 10th enlarged, excavated, 11th longitudinally excavated; metasternum with posterior process

(1229) T. multicostata (Jacoby, 1896)—-metasternum with posterior process; metatibiae with short process at apex

(1230) T. nagaii Mohamedsaid, 1998 - antennae 9th-10th enlarged, oblong; metasternum with posterior process; metatibiae with a short process at apex

(1231) T. nigripennis (Jacoby, 1884)—antennae 9th very large, oblong, 10th enlarged, excavated, 11th longitudinally excavated; metasternum with posterior process

(1232) T. occipitalis (Laboissiere, 1933)—antennae 3rd enlarged, broadly triangular, 8th and 9th thickened; metasternum with posterior process

(1233) T. philippina (Weise, 1913)_antennae 3rd enlarged; metasternum with posterior process

(1234) T. rubida (Allard, 1889) —antennae 6th-9th enlarged, dilated at apex; metasternum with posterior process; metatibiae with a short process at apex
(1235) T. rubripennis (Duvivier, 1884)—metasternum with posterior process

(1236) T. seminigra Reid, 1999-antennae 3rd enlarged, ovoid; metasternum with posterior process

(1237) T. smaragdina (Duvivier, 1888)-antennae 9th enlarged, oblong, 10th dilated at apex, triangular; metasternum with posterior process; metatibiae with a short process at apex

(1238) T. subapicalis Mohamedsaid, 1993-antennae 3rd enlarged, ovoid, 4th angulate; metasternum with posterior process

(1239) T. sucki Weise, 1922-antennae 3rd extremely large, ovoid; metasternum with posterior process; mesotibiae excavated at apical half, dilated at apex

(1240) T. sumatrana (Jacoby, 1899) —antennae 9th-10th enlarged, oblong, dilated at apex; metasternum with posterior process; metatibiae with a short process at apex

(1241) T. tibialis Mohamedsaid, 1994-antennae 3rd enlarged, kidney shaped, deeply excavated, 4th narrowed, curved; protibiae excavated in the middle; metatibiae with a process at apex; metasternum with posterior process

(1242) T. uniformis (Jacoby, 1891) —antennae 3rd enlarged, strongly dilated at apex, medially angulate; metasternum with posterior process.

(1243) T. variceps (Laboissiere, 1933)—antennae 3rd enlarged, much longer than broad, 6th and 7th thickened, each with a tubercle; metasternum with posterior process

(1244) T. ventralis (Baly, 1864)-antennae 10th and 11th enlarged, deeply excavated; metasternum with posterior process

(1245) T. warisan Mohamedsaid, 1998-antennae 3rd enlarged, cylindrical, 4th-11th longitudinally ridged; metasternum with posterior process; metatibiae with a short process

(1246) T. yamamotoi (Mohamedsaid, 1998) — antennae 9th10 th very enlarged, triangular, excavated; metasternum with posterior process; metatibiae with a short process at apex

(1247) Taumaceroides sinicus Lopatin, 2009-antennae 5th6th enlarged, strongly dilated; profemora excavated at apex; protibiae excavated

(1248) Theopea aeneipennis Gressitt and Kimoto, 1963clypeus deeply excavated, with a pair of long projections

(1249) T. azurea Gressitt and Kimoto, 1963-clypeus deeply excavated, with a pair of long projections

(1250) T. elegantula Baly, 1864-antennae 7th, 8th and 9th enlarged, oblong, 10th with a tubercle

(1251) T. flavipalpis Laboissiere, 1940-maxillary palpi swollen 
(1252) T. impressa (Fabricius, 1801)-antennae 5th-7th enlarged oblong, 6th and 7 th each with a tubercle

(1253) T. kedenburgi Weise, 1922-antennae 7th-10th enlarged, oblong, 10th with a tubercle

(1254) T. sauteri Chujo, 1935-antennae 3rd-6th dilated, curved

(1255) T. nigricollis Baly, 1892-antennae 6th-8th enlarged, oblong, 9th and 10th each with a tubercle

(1256) T. smaragdina Gressitt and Kimoto, 1963-clypeus deeply excavated, with a projection

(1257) Therpis smaragdina Weise, 1900-antennae 6th-10th dilated

(1258) Trichobrotica analis (Weise, 1921)—mesotibiae notched

(1259) T. egensis Blake, 1966-mesotibiae notched

(1260) T. nigripennis Blake, 1966-mesotibiae notched

(1261) T. nigrosignata (Jacoby, 1887)—mesotibiae notched

(1262) T. nymphae (Jacoby, 1887)—mesotibiae deeply notched

(1263) T. pallida (Jacoby, 1892)—mesotibiae notched

(1264) T. parviplagiata (Jacoby, 1892)—mesotibiae notched

(1265) T. rhabdota Blake, 1966-mesotibiae notched

(1266) T. ruatanae (Jacoby, 1892)—mesotibiae notched

(1267) Trichomimastra kurnia Mohamedsaid, 2000antennae 8 th, 9th, and 10th enlarged

(1268) Vitruvia clavicornis Weise, 1912-antennae 9th and 10th enlarged, triangular, 11th enlarged, oblong

(1269) Xenarthra calcarata Gerstaecker, 1871-antennae 4th-8th curved

(1270) X. cervicornis Baly, 1861-antennae 2nd-4th broadened, 5 th-7th with a flattened branch, 8 th enlarged

(1271) X. lewisi Jacoby, 1887—antennae 3rd-9th with a long flattened branch

(1272) X. mirabilis Jacoby, 1887-antennae 3rd-10th with a flattened branch

(1273) X. orphana Chapuis, 1879-antennae 4th-8 curved

(1274) X. unicolor Jacoby, 1887-antennae 3rd-9th with a long cylindrical branch

(1275) Xenoda (Xenoda) bakeri Medvedev, 2004-antennae 3rd-8th enlarged, united, oval shaped, 8th with a long, curved spine

(1276) X. (Xd.) carinata Laboissiere, 1929-antennae 3rd8th enlarged, united, oval shaped, 8th with a long, curved spine

(1277) X. (Xd.) luzonica Medvedev, 2004-antennae 3rd8th enlarged, united, oval shaped, 8th with a long, curved spine

(1278) X. (Xd.) nigricollis Jacoby, 1896-antennae 3rd-8th enlarged, united, oval shaped, 8th with a long, curved spine
(1279) X. (Xd.) ovalis Mohamedsaid, 2001-antennae 3rd8th greatly enlarged, united, oval shaped, 8 th with a long straight spine

(1280) X. (Xd.) pallida Jacoby, 1896-antennae 3rd-8th enlarged, united, oval shaped, 8th with a long straight spine

(1281) X. (Xd.) puncticollis Weise, 1922-antennae 3rd-8th enlarged, united, oval shaped, 8th with a long, curved spine

(1282) X. (Xd.) spinicornis Baly, 1877-antennae 3rd-8th enlarged, united, oval shaped, 8 th with a long curved spine

(1283) X. (Xd.) weyersi Duvivier, 1885-antennae 3rd-8th enlarged, united, oval shaped, 8th with a long curved spine

(1284)X. (Paraxenida) brancucci Medvedev, 2004antennae 5th-8th thickened, 8th with a short spine

(1285) X. (Xenodania) vittata Medvedev, 2004-antennae 7 th-10th thickened, 10 th with a sort spine

(1286) X. (Xenodella) abdominalis Jacoby, 1896-antennae 3rd-8th thickened

(1287) X. (Xdl.) basalis Jacoby, 1893-antennae 3rd-7th thickened

(1288) X. (Xdl.) castanea Mohamedsaid, 2001-antennae 3rd-9th thickened

(1289) X. (Xdl.) hitam Mohamedsaid, 2001-antennae 3rd7 th thickened, 8 th very large, oblong, 10th narrowed

(1290) X. (Xdl.) lapan Mohamedsaid, 2001-antennae 3rd7 th thickened, 8 th very enlarged, oblong, 10th broadened

(1291) X. (Xdl.) modiglianii Jacoby, 1893-antennae 3rd7 th thickened

(1292) X. (Xdl.) parvula Jacoby, 1899-antennae 3rd-7th thickened

(1293) X. (Xdl.) setiuensis Mohamedsaid, 2001—antennae 3rd-9th thickened

(1294) X. (Xenodina) cyanipennis Medvedev, 2004antennae 3rd-10th thickened

(1295) X. (Xdn.) fulva Medvedev, 2004-antennae 3rd-10th thickened

(1296) X. (Xdn.) impressa Medvedev, 2004-antennae 3rd10th thickened

(1297) X. (Xdn.) tuberculata Medvedev, 2004-antennae 7th-9th thickened

(1298) Zinjotella stefaninii (Laboissiere, 1927)—antennae 3rd-7th dilated towards apex; elytra with scutellar area elevated. 


\section{Acknowledgments}

This is to acknowledge that several images were downloaded from the following websites, which were then cropped and edited: GBIF Deutschland: http://www.biologie.uni-ulm.de/; MCZ, Harvard University: http://mcz-28168.oeb.harvard .edu/mcz/index.htm; Smithsonian Institution Library for the digital Biologia Centrali-Americana: http://www.sil.si.edu/ DigitalCollections/bca/bca/explore.cfm. The authors wish to thank Karie Darrow (Department of Entomology, National Museum of Natural History, Washington, DC) and Shahnon Mohamed Salleh (Subang Jaya) for their assistance in enhancing some of the figures. Thanks are also extended to Roslan Yusop, Scientific Officer, Centre for Insect Systematic, Universiti Kebangsaan Malaysia (UKM) for the permission to examine specimens in the UKM Collection, Jan Bezděk, Czech Republic and Shawn Clark, USA for providing reprints of their publications where line drawings are used in the present study.

\section{References}

[1] J. J. Gillespie, D. W. Tallamy, E. G. Riley, and A. I. Cognato, "Molecular phylogeny of rootworms and related galerucine beetles (Coleoptera: Chrysomelidae)," Zoologica Scripta, vol. 37, no. 2, pp. 195-222, 2008.

[2] H. Stapel, H. Misof, and T. Wagner, "A Molecular and morphological analysis of Afrotropical Monolepta species and related Galerucinae (Coleoptera: Chrysomelidae)," Arthropod Systematics \& Phylogeny, vol. 66, no. 1, pp. 3-17, 2008.

[3] X. Scherz and T. Wagner, "Revision of Afrocandezea Wagner \& Scherz, 2002 from tropical Africa (Coleoptera: Chrysomelidae: Galerucinae)," Entomologische Zeitschrift-Sttutgart, vol. 117, no. 4, pp. 161-183, 2007.

[4] J. F. Lawrence and A. F. Newton, "Families and subfamilies of Coleoptera," in Biology, Phylogeny and Classification of Coleoptera, J. Pakaluk and S. A. Slipinski, Eds., pp. 779-1006, Museum i Instytut Zoologii PAN, Warszawa, Poland, 1995.

[5] T. N. Seeno and J. A. Wilcox, "Leaf beetle genera (Coleoptera: Chrysomelidae)," Entomography, vol. 1, pp. 1-221, 1982.

[6] D. G. Furth and K. Suzuki, "Character correlation studies of problematic genera of Alticinae in relation to Galerucinae (Coleoptera: Chrysomelidae)," in Proceedings of the 3rd International Symposium on the Chrysomelidae, D. G. Furth, Ed., pp. 116-135, Backhuys, Beijing, Japan, 1994.

[7] S. W. Lingafelter, A. S. Konstantinov, and J. E. Lee, "Systena Chevrolat (Coleoptera: Chrysomelidae: Alticinae): notes on nomenclature, redescription of the genus, and a preliminary discussion of characters and phylogenetic relationships," Proceedings of the Entomological Society of Washington, vol. 100, no. 3, pp. 467-483, 1998.

[8] S. J. Kim, K. M. Kjer, and C. N. Duckett, "Comparison between molecular and morphological-based phylogenies of galerucine/alticine leaf beetles (Coleoptera: Chrysomelidae)," Insect Systematics and Evolution, vol. 34, no. 1, pp. 53-64, 2003.

[9] E. Mayr, Principles of Systematic Zoology, McGraw-Hill, New York, NY, USA, 1969.

[10] L. Hedlund, "Factors affecting differential mating success in male crested newts, Triturus cristatus," Journal of Zoology, vol. 220, no. 1, pp. 33-40, 1990.

[11] M. Andersson, Sexual Selection, Princeton University Press, Princeton, NJ, USA, 1994.
[12] W. G. Eberhard, Sexual Selection and Animal Genitalia, Harvard University Press, Cambridge, Mass, USA, 1985.

[13] W. G. Eberhard, "Postcopulatory sexual selection: darwin's omission and its consequences," Proceedings of the National Academy of Sciences of the United States of America, vol. 106, supplement 1, pp. 10025-10032, 2009.

[14] W. G. Eberhard, "Copulatory courtship and cryptic female choice in insects," Biological Reviews of the Cambridge Philosophical Society, vol. 66, no. 1, pp. 1-31, 1991.

[15] P. Jolivet, "Hypertelie: mimetisme, signaux sexuels ou moyens de defense. Un dilemma chez les insects: vrai ou faux concept?" L'Entomologie, vol. 63, no. 2, pp. 57-66, 2007.

[16] S. Maulik, "On a structure in the antennae of beetles of the chrysomelid genus Agetocera," Proceedings of the Zoological Society of London, vol. 102, no. 4, pp. 943-956, 1932.

[17] S. Maulik, The Fauna of British India, Including Ceylon and Burma, Coleoptera, Chrysomelidae, Galerucinae, Taylor \& Francis, London, UK, 1936.

[18] D. H. Blake, "A review of some galerucine beetles with excised middle tibiae in the male," Proceedings of the United States National Museum, vol. 108, pp. 59-101, 1958.

[19] D. H. Blake, "More new galerucine beetles with excised middle tibiae in the male," Proceedings of United States National Museum, vol. 118, pp. 233-266, 1966.

[20] J. A. Wilcox, "A synopsis of the North American Galerucinae (Coleoptera: Chrysomelidae)," Bulletin of the New York State Museum Survey, vol. 400, pp. 1-226, 1965.

[21] H. Silfverberg, "A revision of the genus Prosmidia Weise (Coleoptera, Chrysomelidae)," Acta Zoologica Fennica, vol. 139, pp. 1-54, 1973.

[22] H Silfverberg, "A generic revision of the group Prosmidiites (Coleoptera: Chrysomelidae)," Entomologica Scandinavica, vol. 13, pp. 173-182, 1982.

[23] W. Freund and T. H. Wagner, "Revision of Bonesioides Laboissière, 1925 (Coleoptera; Chrysomelidae; Galerucinae) from continental Africa," Journal of Natural History, vol. 37, no. 16, pp. 1915-1976, 2003.

[24] G. F. Barroga and M. S. Mohamedsaid, "Phylogeny of the genus Aulacophora chevrolat (Coleoptera: Chrysomelidae: Galerucinae) in sundaland," The Philippine Agricultural Scientist, vol. 89, no. 4, pp. 338-358, 2006.

[25] C. A. M. Reid, "Reappraisal of the genus Taumacera Thunberg with descriptions of two new species from South-East Asia (Coleoptera: Chrysomelidae: Galerucinae)," Australian Journal of Entomology, vol. 38, no. 1, pp. 1-9, 1999.

[26] T. Wagner, "An introduction to the revision of the afrotropical Monolepta and related taxa (Coleoptera, Chrysomelidae, Galerucinae)," CFS Courier Forschungsinstitut Senckenberg, no. 215, pp. 215-220, 1999.

[27] T. Wagner, "Monolepta Chevrolat, 1837, the most speciose galerucine taxon: redescription of the type species Monolepta bioculata (Fabricius, 1781) and key to related genera from (Chrysomelidae, Coleoptera)," Journal of Natural History, vol. 41, no. 1-4, pp. 81-100, 2007.

[28] J. Bezděk, "New species and subspecies of Nymphius (Coleoptera: Chrysomelidae: Galerucinae) from Iran and Turkey," Acta Entomologica Musei Nationalis Pragae, vol. 48, no. 1, pp. 79-93, 2008.

[29] A. P. Moller and A. Pomiankowski, "Why have birds got multiple sexual ornaments?" Behavioral Ecology and Sociobiology, vol. 32, no. 3, pp. 167-176, 1993.

[30] R. A. Johnstone, "Multiple displays in animal communication:'backup signals' and 'multiple messages'” Philosophical 
Transactions of the Royal Society B, vol. 351, no. 1337, pp. 329338, 1996.

[31] W. G. Eberhard, "Beetle horn dimorphism: making the best of a bad lot," The American Naturalist, vol. 119, no. 3, pp. 420 427, 1982.

[32] E. A. Hallem, A. Dahanukar, and J. R. Carlson, "Insect odor and taste receptors," Annual Review of Entomology, vol. 51, pp. 113-135, 2006.

[33] S. Clark, "The western North American genus Androlyperus Crotch, 1873 (Coleoptera: Chrysomelidae: Galerucinae)," Insecta Mundi, vol. 13, no. 3-4, pp. 217-222, 1999.

[34] A. S. Konstantinov and B. A. Korotyaev, "Sexual dimorphism and size of aedeagi in apionid weevils (Coleoptera: Apionidae) and flea beetles (Coleoptera: Chrysomelidae): why some masculine males have small aedeagi," Proceedings of the Entomological Society of Washington, vol. 106, no. 2, pp. 324338, 2004.

[35] M. S. Mohamedsaid and G. F. Barroga, "A study on the morphology of antenna and aedeagus in males of Aulacophora Chevrolat (Coleoptera: Chrysomelidae: Galerucinae)," Oriental Insects, vol. 44, pp. 405-414, 2010.

[36] P. S. M. Hill, "Vibration and animal communication: a review," American Zoologist, vol. 41, no. 5, pp. 1135-1142, 2001.

[37] P. E. Howse, "The significance of the sound produced by the termite Zootermopsis angusticollis (Hagen)," Animal Behaviour, vol. 12, no. 2-3, pp. 284-300, 1964.

[38] F. Roces and B. Holldobler, "Vibrational communication between hitchhikers and foragers in leaf-cutting ants (Atta cephalotes)," Behavioral Ecology and Sociobiology, vol. 37, no. 5, pp. 297-302, 1995.

[39] M. S. Mohamedsaid, "The Galerucinae with sound production devices (Coleoptera: Chrysomelidae)," Entomologische Zeitschrif-Stuttgart, vol. 160, no. 6, pp. 259-262, 2010.

[40] M. Schmitt, "Stridulatory devices of leaf beetles (Chrysomelidae) and other Coleoptera," in Advances in Coleopterology, M. Zunini, X. Belles, and M. Blas, Eds., pp. 263-280, AEC, Torino, Italy, 1992.

[41] M. Schmitt, "Stridulation in leaf beetles (Coleoptera, Chrysomelidae)," in Novel Aspects of the Biology of Chrysomelidae, P. Jolivet, Ed., pp. 319-325, Kluwer Academic, Dodrecht, The Netherlands, 1994.

[42] M. Schmitt, "The position of the Megalopodinae and Zeugophorinae in a phylogenetic system of the Chrysomeloidea (Insecta: Coleoptera)," in Proceedings of the 3rd International Symposium on the Chrysomelidae, D.G. Furth, Ed., pp. 38-44, Backhuys, Leiden, The Netherlands, 1994.

[43] H. E. Hinton, "Secondary sexual characters of Tribolium," Nature, vol. 149, no. 3783, pp. 500-501, 1942.

[44] R. F. Schmitz and M. M. Furniss, "Secondary sex characters of Scolytus laricis," Annals of the Entomological Society of America, vol. 61, pp. 1626-1627, 1968.

[45] B. W. French and L. Hammack, "Sexual dimorphism of basitarsi in pest species of Diabrotica and Cerotoma (Coleoptera: Chrysomelidae)," Annals of the Entomological Society of America, vol. 100, no. 1, pp. 59-63, 2007.

[46] P. Jolivet, "What is a Chrysomelid?" Nouvelle Revue Entomologique, vol. 18, no. 2, pp. 135-146, 2001.

[47] M. S. Mohamedsaid, "Modified antennae of Malaysian Galerucinae and its taxonomic significance," in New Developments in the Biology of Chrysomelidae, P. Jolivet, J. A. SantiagoBlay, and M. Schmitt, Eds., pp. 231-247, SPB Acadamic, The Hague, The Netherlands, 2004.
[48] D. G. Furth and K. Suzuki, "Studies on Oriental and Australian Alticinae genera, based on the comparative morphology of the metafemoral spring, genitalia, and hind wing venation," in Proceedings of the 4th International Symposium on the Chrysomelidae, M. Biondi, M. Daccordi, and D. G. Furth, Eds., pp. 91-124, Atti Museo Regionale Scienze Naturali, Torino, Italy, 1998.

[49] A. G. Böving, "Descriptions of larvae of the genera Diabrotica and Phyllobrotica, with a discussion of the taxonomic validity of the subfamilies Galerucinae and Halticinae (Coleoptera: Chrysomelidae)," Proceedings of the Entomological Society of Washington, vol. 29, no. 9, pp. 193-205, 1927.

[50] A. G. Böving, "Beetle larvae of the subfamily Galerucine," Proceedings of the United States National Museum, vol. 75, no. 2, pp. 1-48, 1929.

[51] A. G. Böving and F. C. Craighead, "An illustrated synopsis of the principal larval forms of the order Coleoptera," Entomologica Americana, vol. 11, pp. 1-351, 1931.

[52] F. A. Lawson, "Chrysomelidae," in Immature Insects, F. Stehr, Ed., vol. 2, pp. 568-585, Kendall-Hunt, Dubuque, La, USA, 1991.

[53] D. G. Furth and J. E. Lee, "Similarity of the Blepharidagroup genera using larval and adult characters (Coleoptera: Chrysomelidae: Alticinae)," Journal of the New York Entomological Society, vol. 108, no. 1-2, pp. 26-51, 2000.

[54] D. G. Furth, "Inter-generic differences in the metafemoral apodeme of flea beetles (Chrysomelidae: Alticinae)," Systematic Entomology, vol. 5, pp. 263-271, 1980.

[55] D. G. Furth, "The metafemoral spring of flea beetles (Chrysomelidae: Alticinae)," Spixiana Supplemente, vol. 7, pp. 11-27, 1982.

[56] D. G. Furth, "The jumping apparatus of Flea Beetles-the metafemoral spring," in Biology of Chrysomelidae, P. Jolivet, E. Petitpierre, and T. Hsiao, Eds., chapter 17, Kluwer Academic, Dodrecht, The Netherlands, 1988. 

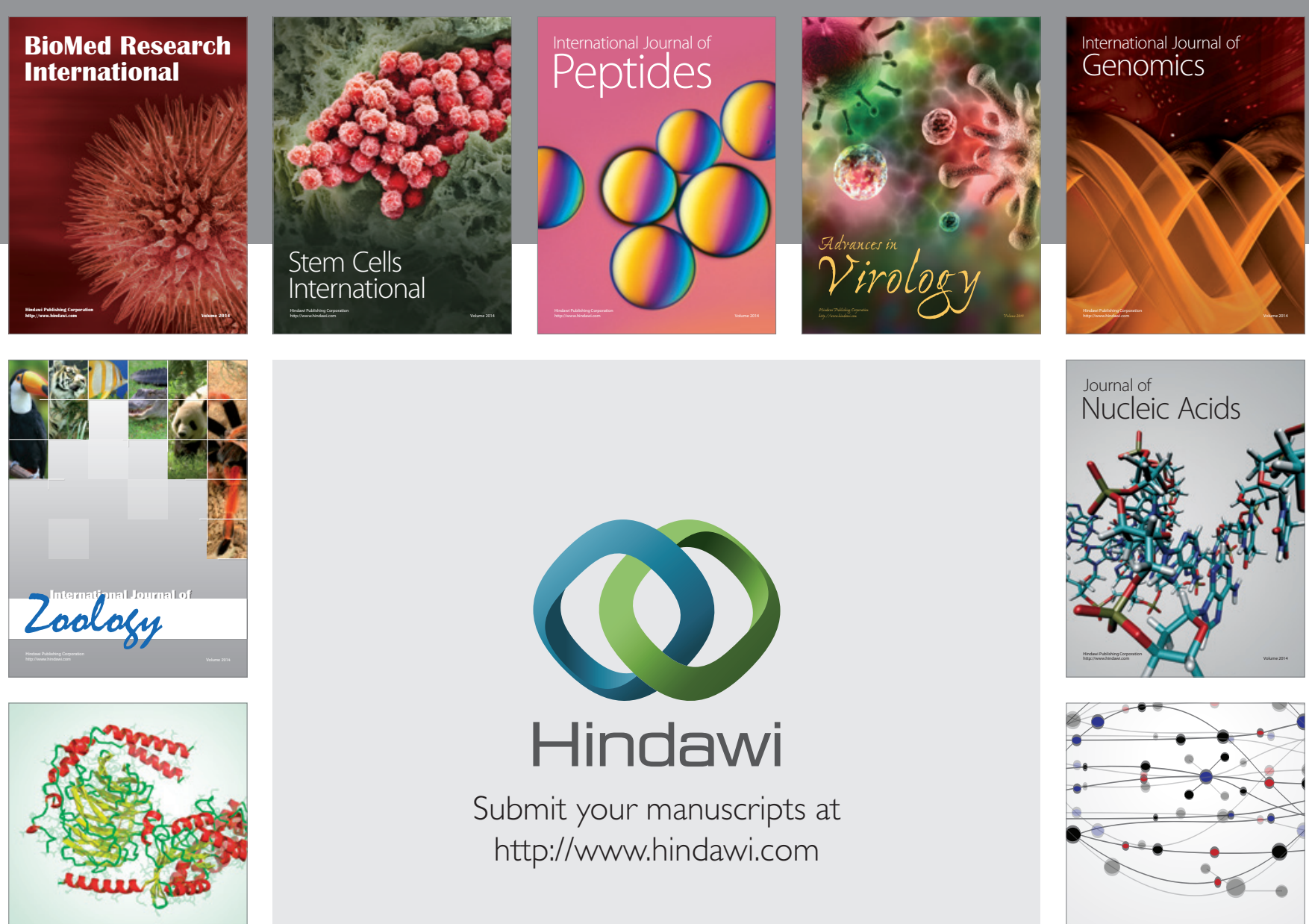

Submit your manuscripts at

http://www.hindawi.com

Signal ${ }^{\text {Jumal }}$ Transduction
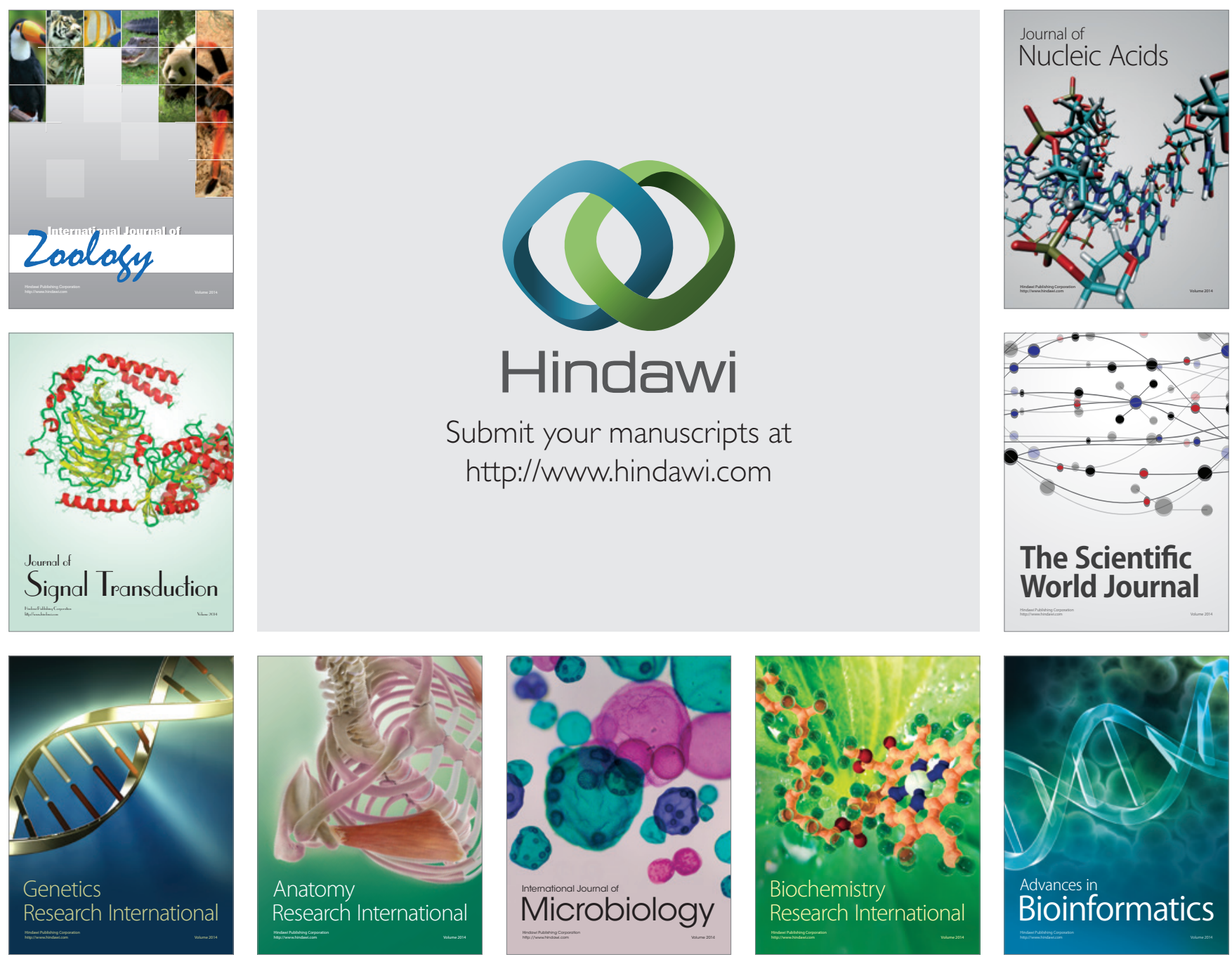

The Scientific World Journal
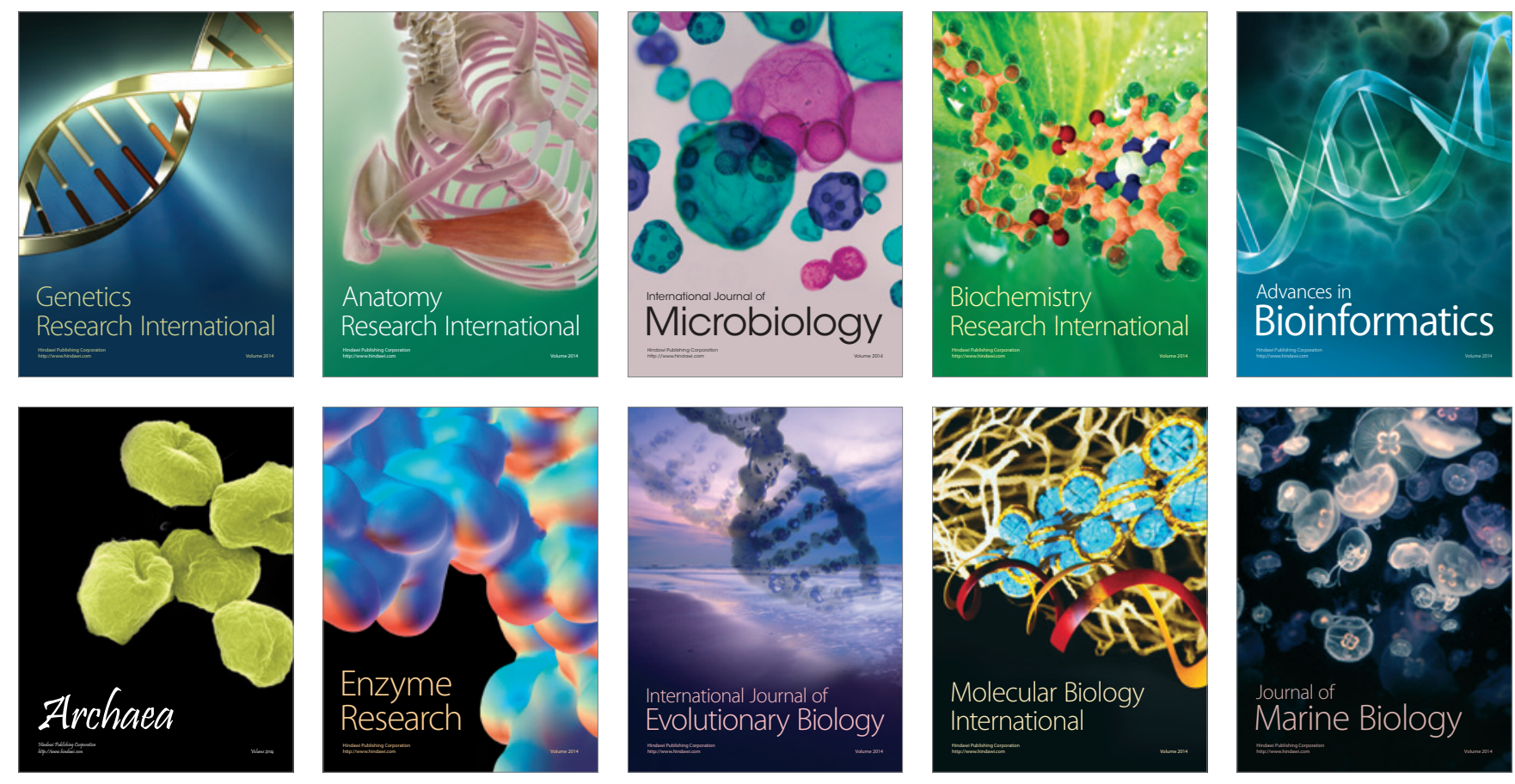